\title{
Articles
}

\section{A Political Theory of Corporate Taxation}

\author{
Jennifer Arlen ${ }^{\dagger}$ and Deborah M. Weiss ${ }^{\dagger t}$
}

\author{
CONTENTS
}

I. INTRODUCTION $\ldots \ldots \ldots \ldots \ldots \ldots \ldots \ldots \ldots \ldots \ldots \ldots \ldots \ldots$

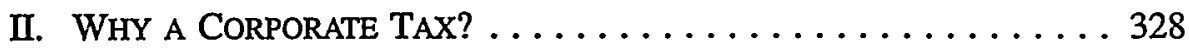

A. Populist Entity Theory . . . . . . . . . . . . 331

B. Rational Populism ........................ 331

C. Congress and Hidden Taxes ................ 332

D. Some Empirical Evidence on Public Opinion ......... 333

E. Summary .............................. 335

III. What MANAgers WANT IN A TAX CUT $\ldots \ldots \ldots \ldots \ldots \ldots 335$

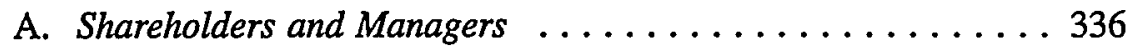

B. Tax Policy .......................... 338

1. Windfalls Versus Benefits to New Investments . . . . . . 338

2. Targeted Tax Cuts ................... 341

3. A Few Managers Prefer Integration ............ 342

+ Professor of Law, University of Southem Califomia Law Center.

it Associate Professor, Stanford Law School. We gratefully acknowledge the helpful comments of Howard Abrams, Barry Adler, Anne Alstott, Joseph Bankman, Bernard Black, Bette Briggs, William Camey, Richard Craswell, Richard Doernberg, Dan Farber, Carr Ferguson, Ron Gilson, Victor Goldberg, Jeff Gordon, Tom Griffith, Lowell Harriss, Louis Kaplow, Michael Klausner, William Klein, Marjorie Kornhauser, Michael Knoll, R.A. Lipsey, Edward McCaffery, Charles McLure, Geoffrey Miller, Daniel Ortiz, James Poterba, Uriel Procaccia, Larry Ribstein, Mark Roe, Roberta Romano, B. Peter Rosendorff, Daniel Shaviro, William Simon, David Skeel, Joseph Snoe, Matt Spitzer, Ethan Stone, Jeff Strnad, Alvin Warren, Mark Weinstein, Bernard Wolfman, Eric Zolt; and participants at workshop sessions at the Columbia University School of Law, University of Southern California Law Center, Stanford Law School, the Stanford Tax Policy Group; and participants at presentations at the 1994 annual meeting of the American Law and Economics Association and the 1994 annual meeting of the Public Choice Society. We also thank Louis Hernandez, Su Hwang, Brian Raphael, and Robert Sturgeon for providing excellent research assistance. Finally, the authors acknowledge the financial support of the Conrad N. Hilton Endowed Fund for the Improvement of the Administration of Justice at the USC Law Center and the George Roberts Program in Law and Business at Stanford Law School. 
C. The Legislative Record . . . . . . . . . . . . . . 342

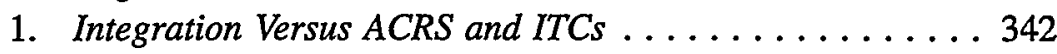

2. Closely Held Firms . . . . . . . . . . . . . . 346

D. Summary ......................... 347

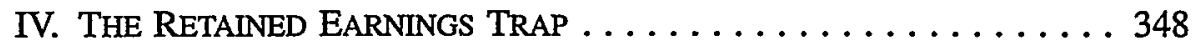

A. Capital Structure . . . . . . . . . . . . . . . 349

B. How the Double Tax Can Trap Earnings ............ 352

C. Do Managers Support the Double Tax to Trap Earnings? . . . 356

1. Does the Double Tax Trap Earnings? . . . . . . . . 356

2. Why Most Managers Will Not Support the Double Tax ... 359

D. Evidence ......................... 361

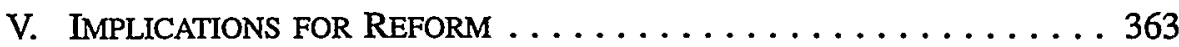

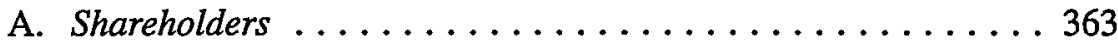

B. Managers ...................... 365

VI. CONCLUSION $\ldots \ldots \ldots \ldots \ldots \ldots \ldots \ldots \ldots \ldots \ldots \ldots$

APPENDIX A: TESTIMONY at INTEGRATION HEARINGS $\ldots \ldots \ldots \ldots 370$

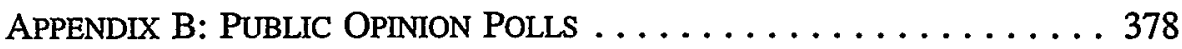

\section{INTRODUCTION}

The American tax system imposes a double tax on the profits of corporations. This two-tier taxation is unusual, ${ }^{1}$ unfair, ${ }^{2}$ and inefficient. The ill-effects of the double tax are well known in Washington. Congress regularly considers legislation to eliminate the double tax by integrating the personal and corporate taxes into a single system. These initiatives have had the support of

1. The United States is one of the few industrialized countries to impose full double taxation on corporate profits. See, e.g., Charles E. McLure, Jr., Where Tax Reform Went Astray, 31 VILL. L. REV. 1619, 1631 (1986).

2. The double tax violates the principle of vertical equity because it imposes a single corporate rate on corporate profits regardless of whether these profits are ultimately attributable to high-income or lowincome taxpayers. Charles E. McLure, Jr., Integration of the Personal and Corporate Income Taxes: The Missing Element in Recent Tax Reform Proposals, 88 HARV. L. REV. 532, 539 (1975); see also id. at 533-41 (refuting arguments made in support of double taxation). But see Jeffrey Kwall, The Uncertain Case Against the Double Taxation of Corporate Income, 68 N.C. L. REV. 613, 633-41 (1990). Some observers argue that the double tax also violates the principle of horizontal equity: Because dividends are taxed differently from other income, the double tax results in similarly situated individuals bearing different tax burdens. McLure, supra, at 538-39; see Kwall, supra, at 633-43. However, unlike vertical inequities, horizontal inequities are often arbitraged away by the market price mechanism. 
tax scholars, the Treasury, the public, and several Presidents. Yet proposals to integrate the tax system invariably die a quiet death.

The persistence of the double-level tax is puzzling. To be sure, the tax code contains many provisions in desperate need of revision. Typically, though, these provisions are supported by a well-organized interest group that lobbies vigorously to retain its cherished preference. The corporate tax, in contrast, appears to benefit no one directly and to hurt the corporate sector, which is large, well organized, and generally able to defend its own interests. Nor does the double tax persist because of public support. Opinion polls regularly show public opposition to double taxation.

In this Article, we argue that the resilience of the corporate tax is a manifestation of the most enduring source of problems in corporate law, the separation between ownership and control of large corporations. Large corporations might be expected to lead the fight against the double tax. Their managers, however, have chosen not to lobby vigorously for integration, even though shareholders often would benefit from integration. In this managerial diffidence lies the key to explaining the failure of integration efforts.

Managers' lack of interest in integration, we argue, results from the fact that managers and shareholders pursue different objectives when firm ownership is separated from control. Shareholder objectives are served both by new investments and by higher returns on old investments. Managerial objectives, in contrast, are served primarily by new investments. This difference in objectives leads shareholders and managers to have different views on corporate investments and on tax policy. Shareholders benefit both from measures such as integration that provide windfalls to their existing shares and from measures such as accelerated depreciation (ACRS) ${ }^{3}$ and investment tax credits (ITCs) that increase the return on new investments. Managers, in contrast, benefit only from policies that stimulate new investment. Thus, while many managers support integration, they would rather devote corporate resources to lobbying for tax preferences, such as ACRS and the ITC, that encourage new investment. ${ }^{4}$

The separation of ownership and control may have an even more surprising consequence. Some managers, we argue, may actively oppose integration because the double tax serves their interests. These managers may support the double tax for one of the very reasons that reformers oppose it: Double taxation traps earnings in the corporation. This retained earnings trap

3. Any income tax system must allow firms to deduct the cost of capital through depreciation allowances. By permitting taxpayers to take these deductions earlier than economically warranted, accelerated depreciation methods (Accelerated Cost Recovery System or ACRS) provide a tax break for capital investment.

4. Interestingly, this divergence between managers and shareholders advances overall economic efficiency; economists are as unenthusiastic as managers about windfalls from tax reforms. 
enables managers to pursue investments from which they benefit at the expense of shareholders.

Understanding the failure of past reform efforts is key to the success of future efforts. Managers have been the only vocal public participants in earlier debates. Reformers, we believe, must secure the support of managers in their quest for integration. Managers, in our view, can be persuaded to support integration by the introduction of proposals that avoid windfalls and, perhaps, those that lock in earnings.

Part II examines alternative explanations of the double tax, including various populist arguments. Parts III and IV examine our hypothesis that the separation of ownership and control explains managerial apathy-and sometimes antipathy-towards integration. Part III examines why most managers have so little enthusiasm for integration: Integration provides a windfall for existing equity, whereas managers would prefer to lobby for tax preferences that promote new investment. Part IV explains why some managers actively oppose integration. Finally, Part V employs our analysis to explore strategies that future reformers might use.

\section{WHY A CORPORATE TAX?}

Under the Internal Revenue Code, the profits of most corporations are, in theory, subject to a two-tier tax. ${ }^{5}$ Each year a corporation's profits are taxed at the corporate level according to a corporate rate schedule. ${ }^{6}$ Any earnings distributed immediately to shareholders as dividends are taxed again as ordinary income at personal rates. ${ }^{7}$ Earnings that are retained by the corporation escape double taxation only temporarily. As these retained earnings generate profits, the new profits are taxed at the corporate level. These earnings are taxed again at the shareholder level when they are distributed or when a shareholder sells his shares.

The corporate tax creates significant efficiency losses. ${ }^{8}$ Some of these losses occur because the tax is effective. By lowering the return to corporate capital, ${ }^{9}$ the corporate tax discourages investment in the corporate sector. ${ }^{10}$

5. See I.R.C. $\S \S 301-381$ (1988) (subchapter C); cf. id. $\$ \S 1361-1375$ (1988) (subchapter \$) (imposing a single tax on certain closely held corporations).

6. Id. \& 11 (West 1995).

7. Id. $\S \S 1,61(\mathrm{a})(7)$ (West 1995).

8. E.g., AMERICAN LAW INST., FEDERAL INCOME TAX PROJECT, INTEgRation OF THE INDIVIdUAL AND CORPORATE INCOME TAXES 21-46 (1993) (Alvin Warren, Reporter) [hereinafter AMERICAN LAW INST., INTEGRATION] (summarizing defects of double tax); George F. Break, Corporate Tax Integration: Radical Revisionism or Common Sense?, in FEDERAL TAX REFORM: MYTHS \& REALITIES 55, 60-63 (Michael J. Boskin ed., 1978) (same); Alvin Warren, The Relation and Integration of the Individual and Corporate Income Taxes, 94 HARV. L. REV. 717, 721-38 (1981); Eric Zolt, Corporate Taxation After the Tax Reform Act of 1986: A State of Disequilibrium, 66 N.C. L. REv. 839, 841-44, 858-68 (1988).

9. There is considerable controversy over who bears the burden of the corporate tax, especially in the long run. Although initially the burden of the corporate tax falls on corporate shareholders, the tax burden may shift, in part or in whole, from corporate shareholders to others, such as labor, firm customers, or 
This may reduce efficiency by lowering output in industries that find a corporate form of organization particularly suitable. ${ }^{11}$ Other losses occur because corporations can avoid the tax, but only by using evasive strategies that impose new social costs. Corporations can, for instance, reduce the burden of the double tax by retaining and reinvesting earnings rather than paying them out as dividends. This strategy will often produce suboptimal investment policies that injure shareholders. ${ }^{12}$ Corporations can also reduce the double tax by financing investment with debt rather than equity, since only corporate equity is subject to the double tax. In so doing, however, a corporation may raise its risk of bankruptcy to inefficient levels. ${ }^{13}$

The double tax, moreover, is inconsistent with currently accepted views of tax equity. ${ }^{14}$ Most contemporary academics regard the corporation as simply a conduit of profits to shareholders and thus see it as an inappropriate unit of taxation. ${ }^{15}$

capital generally. Most would agree, however, that capital does bear some part of the tax. See Thomas Griffith, Integration of the Corporate and Personal Income Taxes and the ALI Proposals, 23 SANTA CLARA L. REV. 715, 728-31 (1983) (concluding that theoretical and empirical literature favors hypothesis that, at least in short run, corporate shareholders bear burden of double tax); Arnold C. Harberger, The Incidence of the Corporation Income Tax, 70 J. POL. ECON. 215, 215-17 (1962). See generally William A. Klein, The Incidence of the Corporation Income Tax: A Lawyer's View of a Problem in Economics, 1965 WIS. L. REV. 576, 581-87 (discussing incidence of corporate tax); Laurence Kotlikoff \& Lawrence Summers, Tax Incidence, in 2 HANDBOOK OF PUBLIC ECONOMICs 1043, 1085-86 (A.J. Auerbach \& M. Feldstein eds., 1987) (same); John K. McNulty, Corporate Income Tax Reform in the United States: Proposals for Integration of the Corporate and Individual Income Taxes, and International Aspects, 12 INT'L TAX \& Bus. LAW. 161, 257-59 (1994) (discussing controversy over who bears burden of corporate tax). This is particularly true in the "short run," when the supply of capital is relatively fixed. See Kotlikoff \& Summers, supra, at 1082. But see MARIAN KRZYZANiAK \& Richard A. Musgrave, THE SHIFTing of THE CORPORATE INCOME TAX, AN EMPIRICAL STUDY OF ITS SHORT-RUN EFFECT UPON THE RATE OF RETURN (1963). Moreover, this short-run effect may last for a substantial period of time; for example, some argue that the adjustment process following a structural tax change is 50 years. Kotlikoff \& Summers, supra, at 1079-81.

10. See, e.g., AMERICAN LAW INST., INTEGRATION, supra note 8, at 22-25; DEPARTMENT OF THE TREASURY, REPORT OF THE DEPARTMENT OF THE TREASURY ON INTEGRATION OF THE INDIVIDUAL AND CORPORATE TAX SYSTEMS: TAXING BUSINESS INCOME ONCE 125-28 (1992) [hereinafter DEPARTMENT OF THE TREasury, Integration]; Charles E. MCluRe, Must Corporate INCOME Be TAXed Twice? 26, 146-48 (1979); Warren, supra note 8, at 732-33.

11. See Break, supra note 8, at 60-63; Harberger, supra note 9 (asserting that in long run corporate tax will shift capital away from corporate sector). Moreover, firms cannot always avoid the double tax by organizing as large limited partnerships because publicly traded limited partnerships are often taxed as corporations.

12. See Break, supra note 8, at 62-63; infra Part IV (discussing retained earnings trap).

13. See AMERICAN LAW INST., INTEGRATION, supra note 8, at 25-28; DEPARTMENT OF THE TREASURY, INTEGRATION, supra note 10, at 115-16; Break, supra note 8, at 61-62. Indeed, concern about excessive leveraging has been one of the driving forces behind integration efforts. See Corporate Taxes: Treasury Official, JCT Head Review Corporate Integration Approaches, Daily Rep. for Executives (BNA) No. 25, at G-9 (Feb. 6, 1990) [hereinafter Corporate Taxes] (quoting Joint Committee on Taxation Chief of Staff Ronald Pearlman as saying that partial integration would resolve problems created by debt-equity distinction); Rick Pullen, Bush Moves Slowly on LBOs, WOMEN's WEAR DAILY, Feb. 8, 1990, at 12.

14. See supra note 2; see also infra Section II.D (noting that public opinion does not support double taxation of corporate profits).

15. See, e.g., William A. Klein, Income Taxation and Legal Entities, 20 UCLA L. REV. 13, 13-16, 43-57, 73-74 (1972). See generally Griffith, supra note 9, at 717-22. This does not mean that academics universally reject the corporate tax. A few academics recently have attempted to justify the corporate tax on grounds unrelated to the separate entity theory, including economic efficiency. These defenses of the 
Integration would considerably reduce many of the problems created by double taxation. ${ }^{16}$ It thus has long had the enthusiastic backing of academic observers, professional groups, ${ }^{17}$ various Treasury Department reports, ${ }^{18}$ and several presidential administrations. ${ }^{19}$ Members of both houses of Congress have introduced a steady stream of bills to integrate the tax system. ${ }^{20}$ Nonetheless, the double tax persists.

corporate tax, however, generally are defenses of a corporate-level tax, not a two-tier tax. See Hideki Kanda \& Saul Levmore, Taxes, Agency Costs and the Price of Incorporation, 77 VA. L. REv. 211, 227, 233-36 (1991); Saul Levmore, The Positive Role of Tax Law in Corporate and Capital Markets, in CORPORATE LAW AND ECONOMIC ANALYSIS 255 (Lucian Arye Bebchuk ed., 1990); Edward McCaffery, Cognitive Theory and Tax, 41 UCLA L. REv. 1861, 1883-86 (1994); see also infra Section II.A (discussing populist explanations for the double tax). Others regard the corporate tax as a remedy for other imperfections in the tax system. See, e.g., Rebecca S. Rudnick, Who Should Pay the Corporate Tax in a Flat Tax World?, 39 CASE W. RES. L. REv. 965, 971-72, 1099-1143 (1988-89) (proposing double tax on liquidity, although only as second-best approach).

16. Throughout this Article we use the term "integration" to refer to both full and partial integration. See infra text following note 37 (discussion full and partial integration plans).

17. See AMERICAN LAW INST., INTEGRATION, supra note 8; AMERICAN LAW INST., FEDERAL INCOME TAX PROJECT, SUBCHAPTER C, PROPOSALS ON CORPORATE ACQUISITIONS AND DISPOSITIONS ADOPTED BY THE AMERICAN LAW INSTTUUTE AT WASHINGTON, D.C., JUNE 13, 1980 AND REPORTER'S STUDY ON CORPORATE DISTRIBUTIONS 354-400, 514 (1982) (William D. Andrews, Reporter); AMERICAN LAW INST., FEDERAL INCOME TAX PROJECT, REPORTER'S STUDY DRAFT-SUBCHAPTER C (SUPPLEMENTAL STUDY) (1989) (William D. Andrews, Reporter) [hereinafter AMERICAN LAW INST., REPORTER's STUDY DRAFT]; TAX DIVISION, AMERICAN INST. OF CERTIFIED PUB. ACCOUNTANTS, INTEGRATION OF THE CORPORATE AND SHAREHOLDER TAX SYSTEMS (1993).

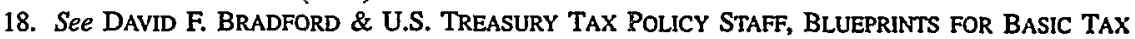
REFORM 4-5, 171 (2d ed. 1984) (slightly revised edition of 1977 Treasury Report of same name) (endorsing full integration); DEPARTMENT OF THE TREASURY, INTEGRATION, supra note 10, at 15, 61-62, 89-92, 120-52 (leaning towards dividend-exclusion plan or comprehensive business income tax); DEPARTMENT OF THE TREASURY, A RECOMMENDATION FOR INTEGRATION OF THE INDIVIDUAL AND CORPORATE TAX SYSTEMS 2-5 (1992) (endorsing reinvestment dividend-exclusion plan); 2 DEPARTMENT OF THE TREASURY, TAX REFORM FOR FAIRNESS, SIMPLICITY, AND ECONOMIC GROWTH 136-37 (1984) [hereinafter TAX REFORM FOR FAIRNESS] (proposing phased-in dividend-deduction system).

19. During the Ford administration, Treasury Secretary William Simon proposed corporate tax integration. See Tax Reform: Public Hearings Before the House Comm. on Ways and Means, 94th Cong., 1st Sess. 3857-58 (1975) [hereinafter Ways and Means Hearings] (testimony of William Simon, Secretary of the Treasury). The proposal was reiterated in Tax Reform Act of 1975: Hearings Before the Senate Comm. on Finance, 94th Cong., 2d Sess. 70-77 (1976) [hereinafter Finance Hearings] (testimony of William Simon, Secretary of the Treasury). The Carter administration seriously considered making an integration proposal. See PETER H. ARANSON, INIERNATIONAL INST. FOR ECONOMIC RESEARCH, ORIGINAL Paper No. 7, The Multiple TaX on Corporate InCome 45 (1977); John F. Witte, The Politics and DeVelopment of THE Federal InCOME TAX 204-05 (1985); Tax Reform Option Papers Prepared by Treasury Department, September 2, 1977, for the White House, Daily Rep. for Executives (BNA) No. 196, at 48-53 (Special Supp., Oct. 7, 1977) [hereinafter Tax Reform Option Papers]. Ronald Reagan supported integration, Norman Jonas, That Wasn't Really a Gaffe on Corporate Taxes, BUS. WEEK, Feb. 14, 1983, at 38,38 , and the Treasury under him issued supportive reports. See, e.g., TAX REFORM FOR FAIRNESS, supra note 18 , at $136-37$ (proposing phased-in dividend deduction system).

20. In 1978, Representative Al Ullman introduced legislation that would have partially integrated the corporate tax. See 124 CONG. REC. 2132-34 (1978) (proposal of Rep. Ullman); 124 CONG. REC. 7978-80 (1978) (statement of Rep. Ullman). Other Bills include S. 1700, 103d Cong., 1st Sess. (1993) (Simon); H.R. 948, 103d Cong., 1st Sess. (1993) (Regula); H.R. 669, 103d Cong., 1st Sess. (1993) (Dornan); S. 3102, 102d Cong., 2d Sess. (1992) (Simon); H.R. 663, 102d Cong., 1st Sess. (1991) (Dornan); H.R. 4707, 101st Cong., 2d Sess. (1990) (Campbell); H.R. 4457, 101st Cong., 2d Sess. (1990) (Vander Jagt); S. 1161, 101st Cong., 1st Sess. (1989) (Shelby); H.R. 1052, 101st Cong., 1st Sess. (1989) (Dornan); H.R. 3668, 100th Cong., Ist Sess. (1987) (Dornan); H.R. 6436, 98th Cong., 2d Sess. (1984), 130 CoNG. REC. 31708 (1984) (Shannon); H.R. 1445, 97th Cong., 1st Sess. (1981), 127 CONG. REC. 1170 (1981) (Sawyer). 
The continued vitality of the double tax has puzzled many observers. A number of scholars have offered explanations for the persistence of the double tax that do not recognize the central role of agency costs. In this part, we will explore these alternative theories. Any theory of corporate taxation, we believe, must explain three facts. First, public corporations are subject to a double tax. Second, although Congress has not integrated the tax system, it regularly enacts other tax measures that reduce the tax burden on corporations. Finally, publicly held corporations have not lobbied for integration. No argument that ignores agency costs, we believe, explains all three of these facts.

\section{A. Populist Entity Theory}

Many scholars have suggested that the double tax persists because the public supports it. ${ }^{21}$ These explanations for voter support of double taxation can be loosely characterized as populist.

In one view, the double tax persists because the public views corporations as distinct entities, not merely as vehicles for transferring profits to shareholders. According to this theory, the public supports the double tax because it believes that all individuals, including corporations, should pay taxes on their income. ${ }^{22}$

The entity theory was indeed the original basis for imposing a separate corporate $\operatorname{tax}^{23}$ and it may in part-though only in part-characterize the public's view of corporations. ${ }^{24}$ Yet even if the public completely accepted it, the entity theory cannot explain all of the stylized facts of corporate taxation. The entity theory can only explain why two levels of tax would be imposed. It has nothing to say about why Congress regularly reduces the burden of corporate taxation through ACRS instead of integration, or why corporations have lobbied more heavily for ACRS than for integration.

\section{B. Rational Populism}

Another populist explanation treats the corporate tax as simply another tax on capital. Voters, in this view, favor the corporate tax because they believe

21. See, e.g., ARANSON, supra note 19, at 34-35; Daniel Shaviro, Beyond Public Choice and Public Interest: A Study of the Legislative Process as Illustrated by Tax Legislation in the 1980s, 139 U. PA. L. REV. 1, 60-61 (1990); see also Barry Adler, Financial and Political Theories of American Corporate Bankruptcy, 45 STAN. L. REV. 311, 345-46 (1993) (suggesting that populist concerns might explain why interest is deductible but dividends are not); Corporate Taxes, supra note 13, at G-9 (reporting Joint Committee on Taxation Chief of Staff Ronald Pearlman's suggestion that double taxation is political necessity).

22. Shaviro, supra note 21 , at $60-61$.

23. See, e.g., MERVYN KING, PUBLIC POLICY AND THE CORPORATION 50 (1977).

24. Poll data on public opinion suggests that the public does not fully accept the entity theory. See infra Section II.D. 
that the tax falls on owners of capital; they do not themselves own significant amounts of capital, ${ }^{25}$ and they feel that those who do should be taxed. ${ }^{26}$

This populist account of the persistence of the double tax fails to explain any of the three fundamental facts. First, even if correct, this argument would at most explain why corporate capital is taxed, but not why profits to capital are taxed twice. ${ }^{27}$ Second, it cannot account for why Congress rejects integration while regularly enacting sweeping capital tax cuts in the form of ACRS, corporate rate reductions, and capital gains cuts. ${ }^{28}$ Finally, it fails to explain why corporate managers lobby more vigorously for ACRS and related cuts than for integration.

\section{Congress and Hidden Taxes}

Some commentators have argued that the corporate tax persists because it serves congressional objectives. The most common variation on this theme is the "hidden tax" argument: The corporate tax is a politically expedient way of raising revenue because the public does not understand that it ultimately bears the burden of the tax. ${ }^{29}$

One version of the hidden-tax argument suggests that taxpayers regard themselves as owners of capital but do not understand that they, as shareholders, pay the corporate tax. This explanation has all the shortcomings of the rational-populist hypothesis. First, it might explain the corporate tax, but it does not explain the additional tax on dividends. Indeed, if voters regard themselves as shareholders, Congress could better hide the tax burden by integrating the tax system, imposing the entire burden directly on corporations,

25. In 1988, only $21.8 \%$ of American households owned corporate shares. JUDITH EARGLE, U.S. DEP'T OF COMMERCE, CURRENT POPULATION REPORTS, SERIES P-70, No. 22, HOUSEHOLD WEALTH AND ASSET OWNERSHIP: 1988, at 2 (1990). Moreover, although a significant percentage of the population is covered by a pension, most pensions are defined-benefit plans in which employees have no stake in the return.

26. Cf. Marjorie Kornhauser, The Morality of Money: American Attitudes Toward Wealth and the Income Tax, 70 IND. L.J. 119, 19-22, 144-54 (1994) (noting implications for taxation of Americans' conflicting views about wealth and equality); Shaviro, supra note 21, at 57,60-61 (arguing that people prefer to pay as little tax themselves as possible, and also wish for wealthy people to "pay their 'fair share"').

27. See also McNulty, supra note 9, at 174 (arguing that possible public belief that shareholders are rich and should be taxed at high rates does not provide policy support for taxing only dividend income at high rates and noting that, moreover, many shareholders are not rich).

28. The 1976 Tax Reform Bill did not include Treasury Secretary William Simon's integration proposal, but it did significantly expand ITCs. See WITTE, supra note 19, at 187, 190-98 (quoting various Senators who characterized bill as creating loopholes for lobbied interests). In 1978, Congress did not adopt Ullman's integration proposal, but passed the 1978 Tax Reform Act, which dramatically increased the tax benefits to new capital. Id. at 204-17.

29. See ARANSON, supra note 19, at 34-36 (proposing this explanation for corporate tax); see also McCaffery, supra note 15, at 1883-86 (employing cognitive psychology to argue that hidden nature of corporate tax is reason to retain it); Shaviro, supra note 21, at 60-61 (describing public misunderstanding of corporate taxation). Congress itself might not understand that the public bears the burden of the tax, but this seems unlikely. The double tax on corporate income is not an isolated, little-known provision of the Code but one of the Code's defining features. In addition, the effects of the double tax have been extensively studied, and there is a remarkable degree of consensus that the double tax is inefficient. 
and allowing shareholders full dividend and capital gains relief. Second, if Congress wanted to hide taxes at the corporate level, it would have little reason to reduce this hidden-tax revenue by enacting measures like ACRS that reduce effective corporate tax rates. Finally, this theory does not explain why corporations do not lobby for integration.

A variant of the hidden-tax argument claims that the corporate tax is shifted, in part or in whole, from corporate shareholders to others, such as labor, firm customers, or capital generally. ${ }^{30}$ According to this argument, voters do not understand that they bear the cost of the corporate tax in the form of reduced wages and higher prices. Because it applies generally to any capital tax, this version of the hidden-tax explanation has the same defect as the rational-populist argument. It cannot explain why two tiers of tax are imposed, why Congress enacts measures like ACRS that reduce effective corporate tax rates, or why public corporations do not lobby for integration. ${ }^{31}$

\section{Some Empirical Evidence on Public Opinion}

Even if correct, the entity, populist, and hidden-tax hypotheses would not explain the current pattern of corporate taxation. The actual evidence of public opinion casts doubt on the premise that the public supports full double taxation. Indeed, public opinion polls present a new puzzle: They suggest that the most politically viable method of taxing corporations should be a system of integration, albeit a partial one.

The public unquestionably supports the imposition of a significant corporate tax. Indeed, public opinion polls reveal that between $65 \%$ and $80 \%$ of those polled favored increasing the corporate tax..$^{32}$ Respondents showed

30. See supra note 9 (discussing tax incidence).

31. Richard Doernberg and Fred McChesney offer another explanation for tax reform that relies on Congress's preferences. They argue that Congress supports those taxes that improve its ability to extract campaign contributions. See Richard L. Doemberg \& Fred S. McChesney, On the Accelerating Rate and Decreasing Durability of Tax Reform, 71 MiNN. L. REV. 913 (1987) thereinafter Doemberg \& McChesney, Rate and Durability]; Fred S. McChesney, Rent Extraction and Interest-Group Organization in a Coasean Model of Regulation, 20 J. LEGAL STUD. 73 (1991). Congress, they argue, often threatens to impose burdens in order to induce groups to bribe congresspersons to induce them to abstain from imposing the burden. Doemberg \& McChesney, Rate and Durability, supra, at 934; Richard L. Doemberg \& Fred S. McChesney, Doing Good or Doing Well?: Congress and the Tax Reform Act of 1986, 62 N.Y.U. L. REV. 891, 898-99 (1987) (book review) [hereinafter Doemberg \& McChesney, Doing Good]; see McChesney, supra; Milton Friedman, Tax Reform Lets Politicians Look for New Donors, WALL ST. J., July 7, 1986, at 12. The desire to extract rents, however, would not cause Congress to resist integration. Many, if not most, integration plans retain the corporate tax. Firms subject to a corporate tax still would have an incentive to "bribe" Congress for relief.

32. See infra Appendix B, Table B.1. When asked whether corporate taxes should be raised to reduce the deficit, this number generally rose, sometimes as high as $80 \%$. Id. Public attitudes did seem sensitive to the manner in which the question was framed. Fewer people opposed lowering the corporate tax than favored raising it. Although about two-thirds supported raising corporate taxes, almost half were unsure whether corporate taxes were too high. Public attitudes towards corporate tax cuts were not affected by the suggestion that cuts might stimulate growth, but respondents supported cuts when the question suggested 
only somewhat more support for reducing dividend taxes than for reducing corporate taxes..$^{33} \mathrm{~A}$ corporate dividend deduction, perhaps viewed as midway between a corporate tax cut and a shareholder-level deduction, drew 50\% opposition. $^{34}$

But support for corporate taxation and dividend taxation does not translate into support for double taxation. At one time the public may have endorsed two-tier taxation. ${ }^{35}$ More recent polls, however, show that no more than $37 \%$ and as little as $29 \%$ of the public supports double taxation. ${ }^{36}$ The apparent contradiction between opposition to double taxation and support for each tax separately probably results from a framing problem. Until pressed, respondents interpret questions about corporate and dividend taxation as general questions about taxing capital.

Unfortunately, the poll data do not draw an important distinction. Some polls asked whether voters favored double taxation of dividends on which corporate tax had been paid. No poll seems to have asked, directly or indirectly, whether respondents favored the double taxation of retained earnings. Public opinion data therefore do not reveal whether the public favors true single-level taxation or favors double-level taxation of retained earnings and single-level taxation of dividends.

This lacuna in poll data is unfortunate. A direct question about double taxation of retained earnings would shed light on voters' concept of the corporation. Public support for single taxation of retained earnings would imply that the public had accepted the academic conduit theory. ${ }^{37}$ Public support for double taxation of retained earnings, however, would be inconsistent with any theory presented so far, including the conduit view. Such support would seem to imply a modified version of the hidden-tax or entity

that cuts might create jobs. One-third of those who supported raising federal corporate taxes to reduce the deficit said they would not continue to support raises if the taxes were passed on to consumers.

33. One poll question, repeated over a number of years, showed $46 \%-54 \%$ in favor of dividend tax reduction and $32 \%-46 \%$ opposed. In $1985,46 \%$ of respondents thought that elimination of the $\$ 100$-perperson exemption on dividend income would make the tax system more fair. Questions suggesting that cuts in dividend taxes might stimulate investment increased support by about $10 \%$. See infra Appendix B, Table B.2.

34. See infra Appendix B, Table B.2.

35. One poll taken in 1949 showed 51\% support for a two-tier tax. A poll taken in 1945 showed $32 \%$ support, although many respondents were unsure of their views. See infra Appendix B, Table B.3.

36. See infra Appendix B, Table B.3. It may, however, be worth noting that in one poll, $42 \%$ of Americans said that they understood the idea of a stock dividend well enough to explain it to someone else. See Lieberman Research, Americans and Their Money, July 1987, available in DIALOG, Poll database (search containing "MONEY" in SOURCE field and "07/00/87" in PD field and "DIVIDEND").

37. Unlike pure integration plans, which achieve full single-level taxation by treating the corporation purely as a conduit for profits that are passed through to shareholders, partial integration plans reduce, but do not eliminate entirely, the double-tax treatment of corporate profits. Because of the lingering appeal of the entity theory, the public might object to a pure integration plan because it eliminates the corporate-level tax. Moreover, particularly in the case of publicly held corporations, pure integration is not administratively practical. 
arguments, in which the public was misled by the corporate veil only when earnings were retained.

The possibility that voters have different views on dividends and retained earnings has intriguing implications for the politics of the corporate tax. Voters who subscribe to the conduit theory should support a pure integration plan. Such a plan would treat the corporation purely as a conduit for profits passed through to shareholders for tax purposes, as in a partnership or Subchapter S corporation. In contrast, voters who are described by a modified hidden-tax theory would not support pure integration, but would support certain partial integration plans, which allow for some double taxation.

Pure integration is not administratively practical, however, and has never been seriously considered in the United States. Instead, the integration plans that have been proposed generally are partial integration plans. In turn, the most popular partial integration plans, referred to as distribution-based methods, would in fact impose a double tax on retained earnings and a single tax on dividends. These methods are regarded as compromises under the conduit approach but constitute the preferred system on the modified-entity and hidden-tax theories. Thus, under either interpretation of the poll data, the public should support this form of partial integration. The poll data thus deepen the mystery of the persistent double tax.

\section{E. Summary}

Neither populist nor hidden-tax arguments can explain the failure of previous efforts to integrate the tax system. In the next two parts, we will examine the motives and behavior of corporate managers, a group ignored by the populist and hidden-tax theories.

\section{What MANagers WANT IN A TAX CuT}

Most wealth in corporate form is held by large, publicly traded corporations. In these corporations, ownership is separated from control: The firms are controlled by professional managers, while firm owners-the shareholders-are largely passive. ${ }^{38}$ But although managers are entrusted with

38. See AdOLF BERLE, JR. \& Gardiner C. MEANS, ThE MOdERn CORPoration AND PRIVATE PROPERTY 7-9 (1932); Ronald Gilson, A Structural Approach to Corporations: The Case Against Defensive Tactics in Tender Offers, 33 STAN. L. REV. 819, 833-36 (1981); see also Bernard S. Black, Agents Watching Agents: The Promise of Institutional Investor Voice, 39 UCLA L. REV. 811, 815-20 (1992) [hereinafter Black, Agents] (discussing limits and benefits of institutional investor monitoring); Bernard S. Black, Shareholder Passivity Reexamined, 89 MrCH. L. REv. 520, 523-26 (1990) [hereinafter Black, Shareholder Passivity] (examining reasons for shareholder passivity but arguing that passivity is not inevitable); Bernard S. Black, The Value of Institutional Investor Monitoring: The Empirical Evidence, 39 UCLA L. REV. 895, 917-27 (1992) [hereinafter Black, Value] (reviewing evidence that large outside shareholders do valuable monitoring). 
guarding shareholder interests, their own interests do not always coincide with those of shareholders. Where the interests of these two groups conflict, managers will attempt to pursue their own interests, even at shareholders' expense. $^{39}$

In this part, we argue that shareholders and managers will often have divergent views on tax policy. The principal difference between them results from their different views on subsidies to existing capital. Shareholders invariably favor policies that increase the return to existing capital; they sometimes, but not always, support policies that stimulate investment. In contrast, managers are primarily concerned with stimulating new investment. They have little interest in increasing the return to existing capital, though they do not actively oppose measures that do this. Managers therefore attach a low priority to integration, which provides a large windfall to existing capital, and only a small stimulus to new investment. Managers prefer to lobby for other tax measures, such as ACRS and ITCs, that may be less advantageous to shareholders but are more cost-effective in stimulating investment.

\section{A. Shareholders and Managers}

Much of the conflict between shareholders and managers arises from the different portfolios they hold. Most shareholders hold fully diversified portfolios and are thus not overly dependent on any one firm. Managers, by contrast, have most of their wealth tied to their corporate employer, largely in the form of firm-specific human capital. These different portfolios produce different attitudes towards the risk of firm failure. ${ }^{40}$ Because most shareholders hold fully diversified portfolios, they are effectively risk-neutral with respect to the risk of firm failure. Accordingly, shareholders want managers to maximize each firm's expected profits without regard to risk. ${ }^{41}$ Managers, however, are heavily dependent on the fortunes of the firm they manage and thus are risk-averse with respect to the risk of firm failure. ${ }^{42}$

39. See, e.g., Eugene F. Fama, Agency Problems and the Theory of the Firm, 88 J. POL. ECON. 288 (1980); Michael C. Jensen \& William H. Meckling, Theory of the Firm: Managerial Behavior, Agency Costs and Ownership Structure, 3 J. FIN. ECON. 305 (1976).

40. See Jensen \& Meckling, supra note 39, at 349-50, 352-53; Alan Marcus, Risk Sharing and the Theory of the Firm, 13 BELL J. ECON. 369 (1982); Susan Rose-Ackerman, Risk Taking and Ruin: Bankruptcy and Investment Choice, 20 J. LEGAL STUD. 277 (1991). See generally Steven Shavell, Risk Sharing and Incentives in the Principal and Agent Relationship, 10 BELL J. ECON. 55 (1979) (describing risk allocation implicit in principal-agent payment arrangements).

41. To the extent that insolvency costs are significant, shareholders will not be completely indifferent to the risk of firm failure. Nevertheless, shareholders in firms that undergo bankruptcy reorganization often retain some of their initial investment if the firm becomes successful after emerging from reorganization. See Jonathan R. Macey, Agency Theory and the Criminal Liability of Organizations, 71 B.U. L. REV. 315, 326 (1991). Moreover, for firms not in the shadow of insolvency, shareholders may be reasonably treated as risk-neutral.

42. See generally RONALD W. MASULIS, THE DEBT/EQUITY ChOICE 47-60 (1988) (describing potential conflicts of interest between stockholders and risk-averse managers); Jensen \& Meckling, supra note 39, at 306, 308-10 (same). Managers of publicly held firms that become insolvent often lose their jobs; those 
Because they are risk-averse, managers will sometimes pursue different investments than risk-neutral shareholders would choose. First, shareholders generally want the firm to pursue any project, however risky, that has positive expected profits. ${ }^{43}$ Managers, by contrast, may avoid some high-risk projects, even though these projects have positive expected profits. ${ }^{44}$ In addition, managers may attempt to reduce the risk of firm failure by diversifying the firm-that is, by expanding the firm into new businesses that face independent risks. Managers may pursue such diversifying investments even when they result in some reduction in firm value. ${ }^{45}$ This reduction in firm value comes at the expense of shareholders, who generally derive no independent benefit from the diversification of any one firm because they already own diversified portfolios. ${ }^{46}$

Portfolio differences may produce another conflict between shareholders and managers. Managers may pursue investment strategies designed not to maximize profits but to secure their positions and increase their salaries. ${ }^{47}$ They may, for example, make their skills more valuable to the firm through irreversible investments in their areas of expertise. ${ }^{48}$ Similarly, managers of

who retain their positions suffer significant reductions in their salary and bonuses. See Stuart C. Gilson \& Michael R. Vetsuypens, CEO Compensation in Financially Distressed Firms: An Empirical Analysis, 48 J. FIN. 425, 440-48 (1993); Lynn M. LoPucki \& William C. Whitford, Bargaining Over Equity's Share in the Bankruptcy Reorganization of Large, Publicly Held Companies, 139 U. PA. L. REV. 125, 149-50 (1990); see also Rose-Ackerman, supra note 40, at 279-97 (arguing that managers fear loss of both job and prestige if firm encounters financial difficulties). For a discussion of the vulnerability of both highly specialized managers and those with more general managerial skills, see, e.g., William J. Carney, Controlling Management Opportunism in the Market for Corporate Control: An Agency Cost Model, 1988 WIS. L. REV. 385, 418-20.

43. But see supra note 41.

44. See generally BERLE \& MEANS, supra note 38, at 119-25; ADAM SMTH, THE WEALTH OF NATIONS 700 (Modern Library ed. 1937) (1776); Jensen \& Meckling, supra note 39, at 306, 308-10. Managers' concern for their reputations may exacerbate their tendency to pursue overly safe projects. Anjan V. Thakor, Corporate Investments and Finance, FIN. MGMT., Summer 1993, at 135, 139-40; see David Hirshleifer \& Anjan V. Thakor, Managerial Conservatism, Project Choice, and Debt, 5 REV. FIN. STUD. 437, 437-39, 465 (1992); see also David Hirshleifer, Managerial Reputation and Corporate Investment Decisions, FIN. MGMT., Summer 1993, at 145 (describing reasons for, and effects of, managers' decision to build personal reputations).

45. See, e.g., Randall Morck et al., Do Managerial Objectives Drive Bad Acquisitions?, 45 J. FIN. 31, 31-32 (1990); Andrei Schleifer \& Robert W. Vishny, Value Maximization and the Acquisition Process, J. ECON. PERSP., Winter 1988, at 7, 13-15; see also Larry H. Lang \& Rene M. Stulz, Tobin's q, Corporate Diversification, and Firm Performance, 102 J. POL. ECON. 1248 (1994) (showing that diversified firms are poor performers relative to firms that are not diversified).

46. Indeed, shareholders of firms pursuing activities with substantial potential tort liability may prefer to organize these activities into separate corporations in order to gain maximum benefit from limited liability.

47. In addition, managers may want to spend more on perquisites and other benefits than shareholders would prefer. See Jensen \& Meckling, supra note 39, at 306, 308-10.

48. Andrei Schleifer \& Robert W. Vishny, Management Entrenchment: The Case of Manager-Specific Investments, 25 J. FIN. ECON. 123, 123-24, 137 (1989). This may also provide managers with another incentive to diversify the firm. Evidence suggests that managing a diversified firm requires special managerial talent, for which firms will compensate managers handsomely. See NANCY L. ROSE \& ANDREA SHEPARD, FIRM DIVERSIFICATION AND CEO COMPENSATION: MANAGERIAL ABILITY OR EXECUTIVE ENTRENCHMENT? 1-6, 18-33 (National Bureau of Economic Research Working Paper No. 4723, 1994). Managers with this particular talent, accordingly, may have an incentive to diversify their firms in order 
firms in declining industries may attempt to preserve their positions by expanding the firm into new businesses, even though shareholder wealth maximization might dictate shrinkage or liquidation.

\section{B. Tax Policy}

Because their interests differ, managers and shareholders have different views on tax policy. Congress can reduce the taxes paid by firms and their shareholders through a number of mechanisms, including integration, reduced corporate tax rates, and increased business tax preferences such as ACRS and ITCs. Congress is unlikely to grant more than a few of these benefits, however, and managers and shareholders differ on the priority that they assign to various policies.

\section{Windfalls Versus Benefits to New Investments}

Shareholders and managers have divergent views on integration largely because they differ in their taste for tax cuts that create windfalls. Virtually any cut in capital taxes will increase the return on new investments, and thus will stimulate investment. This stimulus always helps managers but may or may not help shareholders. Some cuts also increase the return to assets that firms have already purchased. These tax cuts therefore confer a windfall on existing assets, and thereby help existing shareholders. Managers, in contrast, have little to gain from tax cuts that produce windfalls, because windfalls do little to stimulate new investment.

Integration, corporate rate cuts, and capital gains cuts all confer windfalls on existing shareholders. The windfalls result from the fact that the price of any asset reflects expected after-tax returns. Thus, at any given time, the tax treatment of income from the asset is capitalized, or reflected in the price of the asset. When taxes on the asset are cut, the price of the asset rises, giving its owner a windfall. ${ }^{49}$ Integration, corporate rate cuts, and capital gains cuts all lower the total tax burden on both old and new equity, and thus raise the value of existing equity. Owners of existing equity benefit from the increase in the value of their assets even if they do not increase their investment in response to the cut. In contrast, tax incentives such as ACRS and ITCs generally apply only to new assets. An asset already in service when ACRS or an ITC is implemented does not, at least under prevailing rules, receive more favorable depreciation or tax credits.

to maximize their value to the firm.

49. See generally Louis Kaplow, An Economic Analysis of Legal Transitions, 99 HARV. L. REV. 509, 515-16 (1986) (characterizing windfalls from tax cuts as examples of general problems of transition concerns). 
A simple example illustrates the difference between tax cuts that create windfalls and those that do not. Suppose that the economy has two sectors, corporate and noncorporate, and one factor of production, capital. ${ }^{50}$ Capital income from both sectors is subject to a personal-level tax. Assume that corporate income is subject to an additional corporate-level tax at a $50 \%$ rate. Investors demand a return of $6 \%$ before personal taxes but after entity-level taxes. Corporations, therefore, cannot profitably pursue projects that generate less than a pretax return of $12 \%$. Assume that, under this initial tax policy, the equilibrium capital stock is 100 units. A share of stock represents one dollar of capital and produces one unit of output. The output price is $12 \phi$ per unit, so that each dollar of capital produces pretax income of $12 \not$ per year, leaving after-tax income of $6 \%$. Assuming for simplicity that capital does not depreciate, each share is equivalent to a perpetuity of $6 \%$. Since the required rate of return is $6 \%$, the net present value of this perpetuity is $\$ 1 .^{51}$

Suppose that Congress would like to stimulate output and investment. Since the demand for corporate output is inevitably downward-sloping, any increase in output produces a drop in output price and, therefore, in the pretax return to capital. To stimulate investment, then, Congress must cut taxes so that corporations can earn a lower pretax rate of return and still provide shareholders with the required $6 \%$ net marginal rate of return. ${ }^{52}$

The effect of a tax cut on existing shareholders will depend on the type of cut that Congress chooses. A tax break limited to new investment, such as ACRS or an ITC, will lower the tax rate only on income from additional investment. The marginal cost of production will therefore fall, increasing the corporate sector's marginal supply of output to consumers. Equilibrium output will rise to the intersection of this new output supply curve with the existing output demand curve. The price of output will fall. The stimulus effect of this tax cut will actually harm old shareholders. The fall in output prices will depress the pretax return to all shares, while the tax treatment of old capital will stay constant. The value of old shares will therefore decline. ${ }^{53}$ Suppose, for example, that Congress cuts taxes on marginal investments from $50 \%$ to $40 \%$. Suppose that at the new equilibrium, the marginal unit of capital

50. Expanding the analysis to two factors would not significantly alter our conclusion that existing shareholders generally get a windfall when taxes on corporate capital are reduced. In a two-factor world with both capital and labor, under reasonable assumptions, capital still benefits from a fall in capital taxes, although labor may also benefit. See supra note 9. For a more general discussion of tax incidence, see RICHARD TRESCH, PUBLIC FINANCE: A NORMATIVE THEORY 393-409 (1981); Kotlikoff \& Summers, supra note 9.

51. The present value of any perpetuity is $C / r$, where $C$ is the annual cash flow from the perpetuity and $r$ is the interest rate.

52. Strictly speaking, Congress must choose the tax rate that makes the marginal unit of investment pay the required retum. The sentence in the text, which assumes that the required rate of return remains $6 \%$, implicitly assumes that the corporate sector is small or that the supply of capital is perfectly elastic. This assumption is made for the sake of expositional simplicity. The same basic reasoning applies if the tax change does have some effect on the interest rate.

53. See Kotlikoff \& Summers, supra note 9, at 1085-86. 
produces only 0.91 units of output, ${ }^{54}$ and the equilibrium output price falls to $11 \phi$. The pretax return to a unit of new capital would therefore be $0.91(11 \phi)$ $=10 \phi$. The after-tax return to new capital would be the required $6 \phi$. Old capital will still produce one unit of output, but marginal pretax revenue per share will fall from $12 \phi$ to $11 \phi$. After the $50 \%$ corporate tax, the return to old capital will be $5.5 \not .^{55}$ This in turn will lower share value to $92 \not$.

Although an increase in ITCs or ACRS helps only new capital, a rate cut or integration plan will lower the burden on all capital. This reduction in tax rates will confer a windfall on existing equity, although the windfall will be partially offset by the drop in output prices. Using the numbers from the previous example, a general rate cut to $40 \%$ will again cause supply to rise so that equilibrium output price will fall to $11 \phi$; the pretax return to a unit of new capital will again be $10 \phi$; and the after-tax return to new capital will still be the required $6 \phi$. Old capital will again have a marginal physical product of 1 and marginal pretax revenue per share will fall from $12 \phi$ to $11 \phi$. With the new $40 \%$ corporate tax, the after-tax revenue per share of old capital will be $11 \phi(1$ $-0.4)=6.6 \%$. Share value will therefore rise from $\$ 1$ to $\$ 1.10$ (6.6\% represents a $6 \%$ return on $\$ 1.10)^{56}$

Tax cuts that produce windfalls are inefficient tools for stimulating investment. ${ }^{57}$ Windfalls themselves are merely transfers that produce no increase in investment. The revenue loss in a windfall, however, reduces welfare. Congress would either have to reduce spending or make up the lost revenue from other sources, such as a tax on wages. This new tax would create a new deadweight loss of its own by, for example, decreasing the supply of labor.

Because shareholders and managers have different attitudes towards windfalls and investment stimulus, they have different views on tax policy.

54. The example in text assumes, as is probably the case, that the corporate sector has an upwardsloping supply curve. An upward-sloping supply curve could result from either decreasing returns to scale or a resource constraint. In practice, the assumption of no resource constraints is highly implausible for a large segment of the economy such as the corporate sector.

55. For expositional simplicity, the discussion in text implicitly assumes that the marginal physical product of capital is 1 for all units of old capital, and begins to decline only with new capital. In practice, however, if marginal physical product declines at any point, it probably declines at all levels. Thus, old capital other than the last unit probably has a marginal product above 1. Inframarginal units of capital, therefore, earn supernormal returns. These returns will be distributed pro rata among shareholders, so that initial share price will be above $\$ 1$ and final share price will be above $92 \%$. The effect of the tax cut, though, will be as described in text.

56. As noted earlier, a flat corporate supply curve implausibly assumes no resource constraints. See supra note 54 . If, however, the corporate sector has a flat supply curve, the resulting drop in output price will entirely eliminate the windfall to old capital. The new output price will equal the old price minus the tax cut, and after-tax revenue from old shares will be unaffected by the cut. In the example, pretax revenue per share would drop from $12 \phi$ to $10 \%$. Since the tax cut would apply to revenue from old shares, the annual revenue per share after the $40 \%$ corporate tax would be $6 \%$. Share value would therefore remain at $\$ 1$.

57. See Richard A. Musgrave \& Peggy B. Musgrave, Public Finance in Theory and Practice 439 (3d ed. 1980) (noting that, since profitability of new investment is what matters for incentive purposes, rate reduction is less effective than accelerated depreciation or investment tax credit in producing stimulus). 
Shareholders, by definition, own portfolios of existing equity. They therefore gain from policies, such as integration, that provide windfalls to existing equity. While shareholders would like to stimulate new investment, they would prefer not to do so through policies that harm existing equity. Existing shareholders thus generally should prefer integration to tax subsidies for new capital because the tax subsidies decrease the value of existing equity. ${ }^{58}$

Most managers, in contrast, have much to gain from incentives for new investment, and little to gain from windfalls to existing equity. Most managers thus support stimulus measures, such as integration, that provide subsidies to both new and old capital, but generally prefer incentives, such as ACRS and ITCs, that subsidize only new capital..$^{59}$ Tax subsidies for new investment help managers to expand their firms by increasing the after-tax profitability of new investments, thus enabling managers to pursue otherwise unprofitable projects. Managers will therefore lobby for these preferences even if shareholders would prefer integration.

Indeed, to protect existing tax preferences for new capital, some managers may actively oppose integration. The windfall profits from integration would reduce tax revenues. Managers might reasonably fear that the tax revenues lost as a result of integration would be financed by reducing other corporate tax preferences, or by raising the tax rate on the richest individuals. ${ }^{60}$

\section{Targeted Tax Cuts}

For some managers, ACRS and ITCs have another advantage over integration. Corporate managers prefer to lobby on behalf of provisions that help only their firms or industries. ${ }^{61}$ Integration affects all firms, while ACRS and ITCs can be targeted to specific industries. Managers of firms that benefit from ACRS and ITCs are therefore likely to focus their efforts on obtaining these targeted benefits, rather than on integration. ${ }^{62}$

Shareholders, however, do not share managers' preference for targeted tax cuts. They hold diversified portfolios and therefore enjoy the full benefits of across-the-board as well as targeted cuts. Shareholders thus should be less

58. See supra text accompanying note 53.

59. See generally RONALD F. KING, MONEY, Time, \& POLITICS: INVESTMENT TAX SubSIDIES \& AMERICAN DEMOCRACY 285-86, 291, 383, 390, 392 (1993) (documenting consistent business lobbying for tax policies that directly stimulate new investment, such as increased depreciation allowances). Nevertheless, a few managers may prefer integration. See infra Subsection III.B.3.

60. Other managers also might oppose integration even if it were financed from general revenues. See infra Part IV.

61. See Mancur Olson, The logic of Collective Action: Public Goods and the Theory of Groups 147-48 (1965) (arguing that business lobbying is more effective at industry level than at level of entire business community).

62. Certain managers may have an additional reason to prefer ACRS to integration. ACRS favors investments in physical assets, which in turn may promote managerial entrenchment. See generally Schleifer \& Visny, supra note 48 . 
enthusiastic about tax cuts targeted to a single industry. To receive the maximum benefit of targeted cuts, shareholders would have to invest a disproportionate share of their assets in the targeted industry. Such an investment strategy would reduce the diversification of the shareholder's portfolio and therefore increase the overall portfolio risk.

\section{A Few Managers Prefer Integration}

A few managers may nonetheless actively support integration. Some businesses, by their nature, cannot benefit from tax provisions such as ACRS and ITCs. These include firms, such as high technology companies, that have relatively little physical capital. ${ }^{63}$ Like other managers, managers of these firms will advocate preferences, such as tax subsidies for research and development, that benefit new investments that their firms might make. Because such preferences are often not available, managers should support integration and lower rates as the only avenues through which their tax burden can be reduced. ${ }^{64}$

\section{The Legislative Record}

\section{Integration Versus $A C R S$ and ITCs}

The history of tax reform is consistent with our analysis of what policies managers should prefer. Managers have testified in favor of integration, but they have generally reserved their active lobbying efforts for tax preferences for new investments, such as ACRS and ITCs.

Contrary to what many observers believe, ${ }^{65}$ the history of integration efforts shows that many managers have consistently favored integration. A large group of managers has endorsed every legislative initiative to reduce double taxation. The Treasury Department first considered integration seriously in the late 1960s. ${ }^{66}$ Legislative integration proposals were made in 1975 by

63. See Michael S. Knoll, Taxing Prometheus: How the Corporate Interest Deduction Discourages Innovation and Risk-Taking, 38 VILL. L. REV. 1461, 1496 (1994) (noting that high-technology companies tend to rely heavily on intangible capital).

64. Cf. WITTE, supra note 19, at 225 (describing lobbying for safe-harbor leasing rule by businesses that cannot use ACRS credits because they lack taxable income).

65. See, e.g., Lorence L. Bravenec, A Non Traditional Approach to Corporate Integration, 42 TAX NOTES 1381, 1381 (1989) (claiming that managers favor partial integration plans in which corporate taxation would be continued); Robert J. Leonard, A Pragmatic View of Corporate Integration, 35 TAX NOTES 889,895 (1987) (describing lack of enthusiasm in business community for integration); Lee A. Sheppard, The Obstacles to Corporate Tax Integration, 47 TAX NoTES 1168, 1168 (1990) (noting that business owners prefer tax reduction in form other than integration); Laura Saunders, How the Government Subsidizes Leveraged Takeovers, FORBES, Nov. 28, 1988, at 192, 192 (noting that business community sandbagged integration efforts during Carter and Reagan administrations).

66. Interest in integration was stimulated by the report of the Canadian Government's Carter Commission in 1966. See REPORT OF THE ROYAL COMMISSION ON TAXATION (1966). 
Treasury Secretary William Simon, ${ }^{67}$ in 1978 by Representative AI Ullman, ${ }^{68}$ and in 1986 by the Reagan Treasury Department. The first three measures were considered in congressional hearings. Every manager who testified endorsed integration. ${ }^{69}$ Similarly, the 1986 integration proposals prompted numerous letters of support from business leaders. ${ }^{70} \mathrm{~A}$ group of twenty chief executive officers (CEOs) of major companies wrote a letter to Treasury Secretary Baker for the sole purpose of supporting integration. ${ }^{71}$ Other CEOs wrote individual letters supporting integration and tax cuts. $^{72}$

67. See Ways and Means Hearings, supra note 19, at 3857-58 (testimony of William Simon, Secretary of Treasury). The proposal was discussed in Finance Hearings, supra note 19, at 70-77. The proposed plan would have combined shareholder-credit and dividend-deduction methods, with no reinvestment feature.

68. 124 CONG. REC. 2132-34 (1978); 124 CONG. REC. 7978-80 (1978). This proposal would have provided imputation credit treatment for $10 \%$ of dividends. Id.

69. Finance Hearings, supra note 19, at 139-40 (statement of Walker Winter, Chamber of Commerce of United States); id. at 266, 271-72 (statement of Roland M. Bixler, National Association of Manufacturers); id. at 389, 391 (statement of George S. Koch, Chairman, Federal Finance Committee, Council of State Chambers of Commerce); id. at 993, 1011-15 (statement of Dennis P. Bedell, Chairman, American Mining Companies Tax Committee); id. at 1239, 1252 (statement of John T. Higgins, Vice President, Burlington Industries, on behalf of American Textile Manufacturers Institute); id. at 1257, 1271 (statement of Charles W. Stewart, President, Machinery and Allied Products Institute); id. at 1291, 1301-02 (statement of Malcolm R. Lovell, Jr., President, Rubber Manufacturers Association); id. at 1335, 1344 (statement of Norma Pace, Senior Vice President, American Paper Institute); see also infra Appendix A.

70. The 1986 integration proposals were not accompanied by hearings.

71. CEO Tax Group Backs Dividends-Paid Deduction, TAX NOTES TODAY, Aug. 22, 1986, at 51. The signatories were the Chairpersons or CEOs of Allied-Signal Inc., American Can Co., Beneficial Corp., Dart \& Kraft, Inc., Dayton Hudson Corp., Emerson Electric Co., Federated Department Stores, Inc., General Foods, General Motors, Hallmark Cards, Inc., Hewlett-Packard, IBM, J.C. Penney Co., Levi Strauss \& Co., 3M, Merck \& Co., Procter \& Gamble, PepsiCo, Pillsbury, and Sara Lee Corp.

72. See, e.g., Corporate America Comments on Treasury I's Impact on Corporations, TAX NoTES TodAY, June 5, 1985, at 190 (Hamish Maxwell, Chairperson, Philip Morris, supporting integration); Statement by Edmund B. Fitzgerald, Chairperson, President, and CEO, Northem Telecom, in TAX NOTES Microfiche, Doc. 85-2291 (urging phased-in tax cuts and partial dividend deductibility); Statement by Jack F. Bennett, Director and Senior Vice President, Exxon, id. Doc. 85-2659 (letter to editor of New York Times criticizing double taxation); Statement by Stanley C. Pace, Chairperson and President, TRW, Inc., \& Alexander B. Trowbridge, President, National Association of Manufacturers, id. Doc. 85-2719 (supporting tax cuts and partial dividend deductibility); Statement by William W. Berry, President and CEO, Dominion Resources, id. Doc. 85-2722 (same); Statement by Charles F. Zodrow, Roadway Services, Inc., id. Doc. 85-2723 (same); Statement by Robert O. Aders, President and CEO, Food Marketing Institute, id. Doc. 85-2725 (same); Statement by J. Tylee Wilson, Chairperson and CEO, R.J. Reynolds Industries, id. Doc. 85-3244 (calling double taxation "a grossly unfair practice which stifles investment and growth"); Statement by James L. Eichner, Chairperson, Rochester Tax Council and Director of Corporate Tax, Eastman Kodak, id. Doc. 85-3889 (Pub.) (Council composed of Bausch \& Lomb, Inc., Champion Products, Gannett Co., Gleason Corp., Eastman Kodak, R.T. French Co., Schlegel Corp., Security NY State Corp., Sybron Corp., and Xerox, supporting partial deduction for dividends paid and lower tax rates); Statement by William Stiritz, Chairperson and CEO, Ralston Purina, id. Doc. 85-3890; Statement by Paul A. Miller, Chairperson, Pacific Lighting Corp., id. Doc. 85-3891 (supporting dividend deductibility in concept); Statement by Boyd F. Schenk, President and CEO, IC Industries, id. Doc. 85-3892 (supporting partial dividend deduction); Statement by Neil A. Fortkamp, General Manager, Corporate Tax, Internorth, Inc., id. Doc. 85-4088 (supporting integration); Statement by G.K.G. Stevens, Chairperson, Unilever United States, Inc., id. Doc. 85-4089 (supporting partial deduction for dividends); Statement by William R. Howell, Chairperson and CEO, J.C. Penney Co., id. Doc. 85-4092 (supporting a reduction in corporate tax rate and partial deduction for dividends); Statement by Jack A. MacAllister, President and CEO, US West, Inc., id. Doc. 85-4714 (describing importance of "capital formation incentives"). 
Throughout the 1970s and 1980s, business support was reiterated in many less formal settings. ${ }^{73}$

Although managers have supported integration, they have consistently preferred other measures that would reduce corporate sector taxes. ${ }^{74} \mathrm{~A} 1983$ survey of 160 Fortune 1000 executives showed $94.5 \%$ in favor of ITCs, $87.6 \%$ supporting ACRS, and only $70 \%$ in favor of integration. ${ }^{75}$ As one corporate representative said, "We're supportive of the administration's interests, but . . . [ending double taxation] is very, very expensive .... For the same amount of money, there are more powerful ways to reduce the cost of capital . . . like the investment tax credit." $" 76$

Managers' preference for tax reductions for new investments has been reflected in their lobbying efforts. Major lobbying groups have regularly focused their attention on ACRS and other measures designed to stimulate new investment. ${ }^{77}$ The Carter administration decided against introducing an integration proposal, ${ }^{78}$ in part because the business community showed little

73. For example, Mary Kay Ash, President of Mary Kay Cosmetics, said that the elimination of the double tax should be the first priority of tax reformers. Lee A. Sheppard, Corporate Tax Integration, the Proper Way to Eliminate the Corporate Tax, 27 TAX NoTEs 637, 637 (1985). The American Business Conference, which represents midsized growth companies, also advocated integration. Mario P. Borini, The Irrational Partner, INC., Nov. 1984, at 21 (citing support for total elimination of corporate income tax by many, including Conference President Jack Albertine).

74. In the words of Professor Michael Graetz, managers oppose integration because they always ha[ve] a better way to spend the revenue. The better way is on money they have control over. They want a reduction in tax on capital retained by the corporation. They would be happy with something like an investment credit or rapid depreciation. If you will not give them that, they would like a reduction in the corporate rate on retained earnings. But their favorite is not a reduction in the corporate rate that applies only to distributed earnings. It never will be.

SEction of TAXation, AMERICAN BAR ASS'N \& TAX SECTION, NeW YORK State Bar Ass'N, CORPORATE TAX REFORM 161 (1988) [hereinafter CORPORATE TAX REFORM] (comments of Professor Michael Graetz). However, although managerial preference for ACRS has been noted by previous observers, the explanation generally offered has been managerial desire to trap earnings.

75. Tax System Survey, PR Newswire, May 31, 1983, available in DIALOG. A 1993 survey of midsized manufacturers showed the ITC to be the most popular tax reform, with $92 \%$ indicating that its restoration would be beneficial. Midsized Manufacturers Rate ITC Top Tax Benefit, J. ACCT., Aug. 1993, at 30. Eighty-three percent gave such a rating to a reduction in the capital gains tax rate. A 1993 study of corporate executives showed ITCs and ACRS as the preferred tax incentives. Ernst \& Young, Taxation and Corporate Growth, 59 TAX NOTES 131, 132-33 (1993). As this study noted:

Support for these tax incentives varied by industry group. Retailers are the leading supporters of shorter depreciable lives for new assets and financial service executives are strong supporters of capital gains tax cuts. Levels of support also varied by size of the firms: executives with smaller firms supported the idea of capital gains tax cuts in greater percentages than did executives from large- or middle-market companies.

Id. at 133. The Manufacturers' Alliance for Productivity \& Innovation (MAPI) reported that "[t]he vast majority of ... [its members] are more concerned with tax measures such as investment tax credits, depreciation acceleration, and the research credit than with a capital gains rate cut." Correction: Manufacturers' Alliance for Productivity and Innovation, 47 TAX NoTES 763, 763 (1990).

76. Jayne Levin, Treasury Has Three Choices for Ending Double Taxation; And There's Something Wrong with Each, INV. DEALERS' DIG., May 21, 1990, at 49 (quoting Margo Thoming, chief economist of American Council for Capital Formation).

77. See, e.g., WITTE, supra note 19, at 224-25; Edward Cowan, The Quiet Campaign to Cut Capital Gains Taxes-to Zero, N.Y. TIMES, Apr. 12, 1981, § 3, at 8.

78. Wrrte, supra note 19, at 205; see also Tax Reform Option Papers, supra note 19, at 48-53 (outlining proposals of Treasury Department and of Council of Economic Advisors). 
interest in integration, ${ }^{79}$ while actively lobbying for ACRS, ITCs, and other subsidies for new capital. ${ }^{80}$ During the 1978 Ullman hearings, those who expressed concerns about integration condemned the effects of double taxation, but expressed the hope that integration would not diminish other capital incentives. $^{81}$ Businesses that did not press for ACRS lobbied not for integration, but for other tax measures of special benefit to their firms, such as depletion allowances and provisions governing the deductions for foreign tax payments.

During the 1986 tax reform, the first set of proposals for reform, known as Treasury $\mathrm{I}$, advocated phased-in full integration and rate cuts in return for dramatic reductions in ACRS and ITCs. ${ }^{82}$ Most business groups endorsed integration while objecting to reductions in ACRS and ITCs. ${ }^{83} \mathrm{~A}$ few endorsed rate cuts and the repeal of ITCs and ACRS. ${ }^{84}$ This group consisted

79. See James M. Poterba \& Lawrence H. Summers, The Economic Effects of Dividend Taxation, in RECENT ADVANCES IN CORPORATE FINANCE 227, 275 (Edward I. Altman \& Marti G. Subrahmanyam eds., 1985); Francis X. Clines, Corporate Tax Upsets Reagan, N.Y. TIMES, Jan. 27, 1983, at D1.

80. See generally WITTE, supra note 19, at 204-19 (providing detailed political history of Carter-era tax reform).

81. See The President's 1978 Tax Reduction and Reform Proposals: Hearings Before the House Comm. on Ways and Means, 95th Cong., 2d Sess. 6111, 6114 (1978) [hereinafter House Hearings] (testimony and statement of Henry L. Duncombe, Jr., Vice President and Chief Economist, GM); id. at 6260 (statement of American Bankers Association); see also infra Appendix A (showing such sentiments at 1975 and 1978 hearings).

82. TAX REFORM FOR FAIRNESS, supra note 18, at 136-37. The proposal would have begun with a deduction for one-half of dividends and then gradually increased the deductible percentage. Id. The proposal had no reinvestment feature, and therefore would have pressured firms to distribute dividends. See id.

83. See Jeffrey H. Birnbaum, Business Groups, Tax Overhaul Support Wanes, WALl ST. J., Nov. 15, 1985, at 3; U.S. Chamber of Commerce Opposes Some Provisions of Treasury Proposal, TAX NOTES TODAY, May 21, 1985, at 82; TAX NOTES Microfiche, Doc. 85-2291 (Letter from Edmund B. Fitzgerald, Chairman of the Board, Northern Telecom, Inc., to Ronald A. Pearlman, Ass't Secretary for Tax Policy (Mar. 5, 1985)); id. Doc. 85-2719 (Letter from Stanley C. Pace, Chairman of the Board, President and Chief Executive Officer, TRW, Inc. \& Alexander Trowbridge, President, National Association of Manufacturers, to James A. Baker, Secretary of the Treasury (Apr. 22, 1985)); id. Doc. 85-2723 (Letter from Charles F. Zodrow, Chaiman of the Board, Roadway Services, Inc., to Ronald A. Pearlman, Ass't Secretary for Tax Policy (Mar. 18, 1985)); id. Doc. 85-3889 (Letter from James L. Eichner, Chairman, Rochester Tax Council and Director of Corporate Tax, Eastman Kodak Co., to James A. Baker, Secretary of the Treasury (Apr. 22, 1985)); id. Doc. 85-3892 (Letter from Boyd F. Schenk, President and Chief Operating Officer, IC Industries, to James A. Baker, Secretary of the Treasury (Apr. 9, 1985)); id. Doc. 85-4092 (Letter from William R. Howell, J.C. Penney Co., to Richard Darman, Deputy Secretary of the Treasury (Apr. 22, 1985)).

84. See, e.g., Campbell Soup Co. Supports Dividends Deduction, TAX NOTES TODAY, May 21, 1985, at 75; Emerson Electric Supports Administration Reform Proposals, TAX NOTES TODAY, Aug. 6, 1985, at 89 (Letter from Charles F. Knight, Chairman and Chief Executive Officer, Emerson Electric Co., to James A. Baker, Secretary of the Treasury (July 2, 1985)) (rejecting idea that traditional manufacturers would be hurt by proposed tax reforms); IBM Says to Lower Tax Rates and Not to Distinguish Among Sources or Uses of Income, TAX NOTES TODAY, May 29, 1985, at 74; PepsiCo Favors Tax Reform in Letter to Rostenkowski, TAX NoTES TODAY, Oct. 22, 1985, at 76 (Letter from David L. Wright to James A. Baker, Secretary of the Treasury, and attached letter from J.H. Ditkoff to Dan Rostenkowski, Chairman, Committee on Ways and Means, U.S. House of Representatives (Oct. 4, 1985)); PepsiCo Opposes ACRS Recapture, Supports Other Reforms, TAX NoTES TODAY, July 30, 1985, at 113 (Letter from J.H. Ditkoff to James A. Baker, Secretary of the Treasury (July 16, 1985) and attached position paper supporting lower corporate tax rate and other tax reform proposals); TAX NOTES Microfiche, Doc. 85-2722 (Letter from William W. Berry, President and Chief Executive Officer, Dominion Resources, to James A. Baker, Secretary of the Treasury (Mar. 5, 1985)); id. Doc. 85-3890 (Letter from William P. Stiritz, Chairman and Chief Executive 
primarily of managers of firms that had little to gain from ACRS, for example firms that are not physical-capital-intensive, such as IBM and Proctor \& Gamble. ${ }^{85}$

\section{Closely Held Firms}

In closely held firms, control and ownership are linked. The managers of these firms therefore have the same tax policy objectives as shareholders.

If agency costs explain the persistence of double taxation, closely held corporations should be able to reduce or avoid double taxation of their income. In fact, a closely held firm can lower the double tax in a variety of ways. Shareholders of closely held corporations are often also employees of the firm. The firm thus can organize as a Subchapter $\mathrm{C}$ corporation and still largely avoid the double tax by paying these shareholder/employees substantial salaries. These payments are taxable to the recipient, but deductible to the corporation as an ordinary and necessary business expense. Thus, only a single level of tax is paid.

Closely held firms also can choose an organizational form that is not subject to two-tier taxation. The firm can organize as a partnership or as a nonpublicly traded limited partnership, both of which are subject to a singlelevel tax. Alternatively, it can organize as a Subchapter S corporation, which retains the benefits of the corporate form but is taxed like a partnership. ${ }^{86}$

Indeed, over the past few decades, a striking pattern has emerged. Congress has steadily expanded the scope of Subchapter $S$, while retaining the restrictions that limit its applicability to closely held corporations. ${ }^{87}$ In contrast, in 1986 Congress reclassified publicly traded partnerships as corporations for tax purposes. Firms in which ownership is separated from control thus generally bear the double tax, regardless of whether they are organized as corporations. Yet closely held firms, including closely held corporations, can generally avoid the double tax. ${ }^{88}$

Officer, Ralston Purina Co., to James A. Baker, Secretary of the Treasury (Apr. 16, 1985)).

85. See Jeffrey H. Bimbaum, Growing Divisions in Business, Congress Suggest Tax Bill Faces Fight in House, WaLl ST. J., Nov. 27, 1985, at 52. Allied Signal and General Motors also supported the bill. Id. Pacific Lighting Corporation, by contrast, endorsed corporate rate cuts but opposed the repeal of ACRS and ITC. See TAX Notes Microfiche, Doc. 85-3891 (Letter from Paul A. Miller, Chairman of the Board, Pacific Lighting Corp., to James A. Baker, Secretary of the Treasury (Apr. 23, 1985) and attached position paper).

86. For tax purposes, Subchapter $S$ corporations pass income and losses through to shareholders each year, regardless of whether they actually distribute earnings. This pass-through tax replaces the double tax with a single-level shareholder tax.

87. Not every closely held firm is owner managed. Some are controlled by professional managers. In this situation, many of the agency costs discussed previously will affect managers" views of investment and tax policy. Nevertheless, the owners will exert more control over the firm and may either be able to dictate firm lobbying policy directly or engage in lobbying themselves. See Harold Demsetz \& Kenneth Lehn, The Structure of Corporate Ownership: Causes and Consequences, 93 J. POL. ECON. 1155, 1158-60 (1985) (arguing that when control is concentrated shareholders are better able to monitor managers).

88. Rudnick, supra note 15 , at $971-73$. 
Recent changes in state incorporation statutes also provide evidence that managers of closely held firms support integration. Many states are developing novel forms of business organizations, such as the limited liability company, that are designed to permit small businesses to benefit from limited liability while still retaining the single-level tax. ${ }^{89}$ These novel business forms are intended to confer pass-through taxation on closely held firms. Consistent with the general evolution of double taxation, however, a limited liability company that effectively separates ownership and control may find itself subject to the double tax..$^{90}$

The so-called corporate tax is therefore paid by virtually all publicly held entities, even those that are not corporations, and is not paid by closely held entities, even those organized as corporations. This evolution suggests that owner-managers have successfully pressed for a single-level tax, while public managers have not. ${ }^{91}$

\section{Summary}

Most integration plans would subsidize old capital. Most managers do not oppose this, but, because their interests differ from those of shareholders, they place a lower priority on integration than on ACRS, ITCs, and other tax preferences for new investments. To the extent managers seek to influence tax reform, they serve their own interests, not those of shareholders: They expend their energy in favor of tax preferences for new capital, not integration. Indeed, some managers may even oppose integration because they fear that it may come at the expense of reduced tax preferences.

The windfall effects of integration do not, without more, show that managers have influenced corporate tax policy. Rational policymakers who want to stimulate investment might favor tax cuts limited to new investments, since these are less costly to implement. Congress, however, does not avoid all windfall tax measures. Rational congressional concern for windfalls cannot explain why capital gains cuts have been common and corporate rate cuts not unheard of while proposals to integrate the tax system have found little support. Indeed, because capital gains cuts apply to a broad range of assets, they create even more significant windfalls than integration would.

89. See William A. KLEIN \& John C. COFFE, JR., BuSinesS ORganization AND FinanCE: Legal AND ECONOMIC PRINCIPLES 102-04 (5th ed. 1993); 1 LARRY E. RIBSTEIN \& ROBERT R. KEATINGE, RIBSTEIN AND KEATINGE ON LIMITED LIABILITY COMPANIES \$§ 1.02-1.06 (1995).

90. See KLEIN \& COFFEE, supra note 89, at 103-04 (noting tax risks of delegation of management in limited liability company).

91. The divergent views of publicly and closely held companies may also be evidenced by the response of the tax bar to the recent integration debate. The bar has minimized the importance of integration for publicly held corporations while insisting on the need for expanded integration for closely held entities. See J. Andrew Hoerner, Integration Through the Back Door: Expanded Passthroughs Gain Support, 54 TAX NoTES 930, 930-31 (1992). 
By contrast, pressure from managers can explain why certain windfall tax cuts, such as corporate rate and capital gains cuts, are enacted, while integration plans are essentially ignored. Managers are not only concerned with preserving tax subsidies to new investments; many also are concerned with their ability to retain earnings. Even if tax preferences for new investment were left intact, integration would reduce some managers' access to retained earnings, thereby reducing their ability to pursue new investments. The next part will discuss how this effect should cause some managers to actively oppose integration and to prefer measures that increase access to retained earnings, such as corporate rate and capital gains tax cuts.

\section{THE RETAINED EARNINGS TRAP}

Most managers support integration but have not lobbied on behalf of it. A small group of managers, however, has actively opposed integration, including proposals that would not reduce incentives to new capital. In this part, we will examine the reason for their opposition.

Managers of publicly held firms often want to pursue suboptimal investment policies. ${ }^{92}$ They cannot make suboptimal investments, however, if shareholders can monitor effectively the firm's investment policy. Retained earnings are accompanied by less monitoring than other forms of finance, and managers consequently prefer them to other sources of capital. Shareholders, in turn, dislike retained earnings financing precisely because it insulates managers from scrutiny. ${ }^{93}$

The double tax raises the cost to shareholders of dividend distributions, thus increasing shareholders' taste for retained earnings. Some managers therefore may prefer a double tax even to integration coupled with comparable incentives for new investment. ${ }^{94}$ This group of managers, however, is likely

\section{See supra Section III.A.}

93. The conclusion that dividend policy does affect the value of the firm is consistent with most of the modern theoretical and empirical literature but stands in direct contrast with the Modigliani and Miller Irrelevance Theorem. See Merton H. Miller \& Franco Modigliani, Dividend Policy, Growth, and the Valuation of Shares, 34 J. BuS. 411 (1961). Modigliani and Miller assumed that the firm's investment strategy was fixed. See id. at 412 . Our argument follows more recent analyses in assuming that capital structure affects investment strategy because different forms of financing produce different levels of monitoring.

94. No previous author seems to have argued, as we did in Part III, that corporate managers are uninterested in integration because it would create a windfall. Many tax reformers, however, have suggested, without exploring in detail, the possibility that integration attempts have been frustrated by managerial desire to preserve the retained earnings trap. See, e.g., Bravenec, supra note 65, at 1361 (noting corporate managers' disfavor of full integration and support for various forms of partial integration); Comprehensive Analysis of Integration to Precede Any Legislation, Official Says, Daily Rep. for Executives (BNA) No. 13, at G-5 (Jan. 19, 1990) [hereinafter Comprehensive Analysis] (quoting Assistant Secretary for Tax Policy Kenneth Gideon); Leonard, supra note 65, at 895 (noting corporate manager disapproval of previous partial integration proposals); Saunders, supra note 65, at 192 (quoting Donald Lubick as saying that managers oppose integration because they want "to keep their fingers on the money"). We are, to our knowledge, the first to fully analyze this possibility. 
to be quite small..$^{95}$ As a result, an integration plan that eliminated the retained earnings trap but avoided the windfall problem might be politically feasible.

\section{A. Capital Structure}

The investment objectives of managers of publicly held firms differ from those of shareholders. Shareholders accordingly attempt to monitor the managers' investment decisions to prevent investments that do not maximize shareholder profits. Managers, in turn, often seek to avoid this monitoring.

The monitoring to which firms are subject depends in large part on how the firm's capital needs are financed. Firms can obtain capital to finance new investments from three sources: retained earnings, new equity, or debt. Managers generally are subject to less monitoring when they employ retained earnings financing than when they use external financing from debt or new equity. ${ }^{96}$

External financing facilitates monitoring through several mechanisms. To obtain external financing, managers must disclose substantial amounts of information and subject the firm's operations to the scrutiny of the capital markets. ${ }^{97}$ Managers will have trouble obtaining external financing for a

95. See infra Section IV.C.

96. See Frank H. Easterbrook, Two Agency-Cost Explanations of Dividends, 74 AM. ECON. REv. 650, 653-54 (1984); Michael C. Jensen, Agency Costs of Free Cash Flow, Corporate Finance, and Takeovers, 76 AM. ECON. REV. (PAPERS \& PROC.) 323 (1986); see also Sanford J. Grossman \& Oliver D. Hart, Corporate Financial Structure and Managerial Incentives, in THE ECONOMICS OF INFORMATION AND UNCERTAINTY 107 (John J. McCall ed., 1982) (presenting theory of debt as management's bonding or precommitment device). See generally RICHARD A. BREALEY \& STEWART MYERS, PRINCIPLES OF CORPORATE FINANCE 325 (4th ed. 1991) ("If [managers] want a quiet life, they will avoid going to the capital market for new cash and they will retain sufficient earnings to give them some financial slack.").

The claim that shareholders prefer external financing to internal financing because of the increased monitoring (with managers preferring internal financing for this reason) is known as the "free cash flow" theory. William G. Christie and Vikram Nanda have found empirical support for the free cash flow theory. See William G. Christie \& Vikram Nanda, Free Cash Flow, Shareholder Value, and the Undistributed Profits Tax of 1936 and 1937, 44 J. FIN. 1727 (1994). In addition, the evidence suggests that managers of firms characterized by separation of ownership and control appear to prefer to retain earnings to meet the firms' financial needs, including the financing of expansion. See KLEIN \& COFFE, supra note 89, at 358 (citing Stewart C. Myers, The Capital Structure Puzzle, 39 J. FIN. 575 (1984)). Firms that do not issue new equity exhibit a lower rate of return on reinvested earnings. Id. at 359; see MERRITT B. FOX. FINANCE AND INDUSTRIAL PERFORMANCE IN A DYNAMIC ECONOMY 234-35 (1987) (citing William J. Baumol et al., Earnings Retention, New Capital, and the Growth of the Firm, 52 REv. ECON. \& STAT. 345, 345-55 (1970) and W.J. Baumol et al., Efficiency of Corporate Investment: Reply, 55 REV. ECON. \& STAT. 128, 128-31 (1973)).

97. Although many large firms can issue securities employing Form S-3-which permits them to employ a registration statement that in large part simply incorporates by reference filings made under the 1934 Securities Exchange Act-the process of issuing securities still may bring additional information to the market. See Form S-3, 17 C.F.R. $\$ 239.13$ (b)(2) (1985), reprinted in 2 Fed. Sec. L. Rep. (CCH) 17152. First, a Form S-3 offering will require the services of an underwriter, who is required to perform due diligence to determine the veracity of the statements made in the registration statement. Similarly, in the case of debt, rating agencies will examine the firm. Finally, a firm seeking to avoid the costs of a registered offering may find itself subject to particularly intense scrutiny because the market for unregistered offerings is dominated by large financial institutions, who are particularly able to scrutinize firms' finances. See 
suboptimal project. Equity investors will not knowingly volunteer capital for projects that generate a below-market rate of return; creditors, in turn, will insist on charging a higher interest rate than they would charge if the firm were pursuing an optimal project, since a suboptimal project will increase the firm's risk of default.

In many respects, then, external financing shifts the final decision to pursue an investment from managers to outsiders. To preserve their decisionmaking power, managers can finance projects with retained earnings. Shareholders cannot easily monitor managers' use of these earnings. ${ }^{98}$ Even if shareholders learn of a suboptimal project, they have, under the Business Judgment Rule, ${ }^{99}$ almost no right to prevent managers from pursuing it. Accordingly, managers who wish to pursue suboptimal investment policies will strongly prefer to finance growth through retained earnings. Shareholders, in turn, will want managers to distribute earnings and to finance new projects with newly issued equity or debt securities. ${ }^{100}$

Managers' preference for retained earnings financing often will be reinforced by managerial compensation schemes. An executive stock option plan will generally induce managers to reduce corporate dividends because payment of a dividend decreases the per-share price and thus decreases the value of the unexercised stock option. ${ }^{101}$ In this respect, executive stock

Securities Act of 1933, 15 U.S.C. § 77(d)(1)-(2) (1994); 17 C.F.R. \$\$ 230.144-144A, 230.501-508 (1995); see also FRANK H. EASTERBROOK \& DANIEL R. FISCHEL, THE ECONOMIC STRUCTURE OF CORPORATE LAW 46 (1991) (noting that banks and other financial institutions may be particularly good monitors of major corporate decisions); Barry E. Adler, An Equity-Agency Solution to the Bankruptcy-Priority Puzzle, $22 \mathrm{~J}$. LEGAL STUD. 73 (1993) (arguing that creditors serve valuable monitoring function in determining whether to issue debt); Saul Levmore, Monitors and Freeriders in Commercial and Corporate Settings, 92 YALE L.J. 49, 56 (1982) (finding banks to be excellent monitors because of their experience, sophistication, and access to debtor assets and records); cf. Black, Value, supra note 38, at 927-31 (discussing empirical evidence from Germany and Japan suggesting that large equity holdings by banks and other financial institutions correlate with improved profitability).

98. See BERLE \& MEANS, supra note 38, at 7-9; Jensen \& Meckling, supra note 39, at 312-30; see also Black, Agents, supra note 38, at 834-39 (discussing limits of institutional-investor monitoring); Black, Shareholder Passivity, supra note 38, 523-26 (examining reasons for shareholder passivity); Black, Value, supra note 38, at 917-27 (discussing empirical evidence of benefits of institutional-investor monitoring).

99. Under the Business Judgement Rule, courts generally will not review the substantive merits of managers' decisions, particularly investment decisions, unless the shareholder can prove that the managers had a conflict of interest or failed to exercise due care in the process of making the decision (i.e., failed to obtain sufficient information). In practice, absent self-dealing, poor investment decisions thus generally cannot be challenged. See KLEIN \& COFFEE, supra note 89, at 150-54.

100. Easterbrook, supra note 96, at 653-54; Jensen, supra note 96 .

101. See KLEIN \& COFFE, supra note 89 , at 288,377 . This problem arises because executive stock option plans generally are not dividend protected. Richard A. Lambert et al., Executive Stock Option Plans and Corporate Dividend Policy, 24 J. FIN. \& QUAN. ANAL. 409, 412-14 (1989). The empirical evidence generally confirms this relationship between stock options and dividends. See Jennifer J. Gaver \& Kenneth M. Gaver, Additional Evidence on the Association Between the Investment Opportunity Set and Corporate Financing, Dividend, and Compensation Policies, 16 J. ACCT. \& ECON. 125, 137-56 (1993); Lambert et al., supra, at 418-23; Clifford W. Smith, Jr. \& Ross L. Watts, The Investment Opportunity Set and Corporate Financing, Dividend, and Compensation Policies, 32 J. FiN. ECON. 263, 270, 287 (1992). But see Richard A. DeFusco et al., The Association Between Executive Stock Option Plan Changes and Managerial Decision Making, 20 FIN. MGMT. 36 (1991) (finding that dividend payout ratio increases after stock option plans are announced). For a detailed discussion of the tax treatment of stock option plans, see 
option plans may increase the conflict between stockholders and managers over the source of financing.

This is not to say that shareholders invariably prefer external financing to retained earnings financing, nor that managers invariably avoid external financing. For example, shareholders may prefer internal financing if internal financing is less costly than external financing because of transaction costs or asymmetric information. ${ }^{102}$ Managers, in turn, may sometimes want additional monitoring as a way of bonding themselves to shareholders. ${ }^{103}$ Nevertheless, managers will usually want less monitoring than shareholders and therefore will have a greater taste than shareholders for retained earnings financing. ${ }^{104}$ Managers thus have an incentive to devise ways to reduce shareholder pressure to distribute earnings. ${ }^{105}$

Myron S. Scholes \& MARK A. Wolfson, TAXes AND Business Strategy: A PLANNing APPROACH 185-91 (1992).

102. See BREALEY \& MYERS, supra note 96 , at 345 (outlining costs of external financing). One variant of this argument is the "pecking order" theory, which examines how shareholders will react to information about managers' financing choice, assuming that managers have more information and that managers are selecting the method of financing that maximizes the value of existing equity. When managers are better informed than the market, the market will view external financing as a signal that managers think the firm is overvalued. A new equity issue thus will depress the price of existing equity. The signaling effect of financing, it is argued, creates a "pecking order" with internal financing being preferred to debt and debt to external financing. See Stewart C. Myers \& Nicholas S. Majluf, Corporate Financing and Investment Decisions When Fims Have Information That Investors Do Not Have, 13 J. FIN. ECON. 187 (1984); cf. BREALEY \& MYERS, supra note 96, at 345 (discussing one study of almost 9000 new issues done between 1960 and 1987 that found average underpricing of 16\%) (citing R.G. Ibbotson et al., Initial Public Offerings, 1 J. Applied Corp. Fin. 37 (1988)). But see JeAN Helwege \& Nellie LaNG, Federal Reserve boARd, FinanCe AND ECONomics Discussion SERIES, PAPER No. 94-22, Is THERE a PeCKing ORDER? EVIDENCE FROM A PANEL OF IPO FIRMS 16-21 (1994) (presenting empirical study failing to confirm pecking order theory). Even if correct, the "pecking order" theory does not alter our analysis. First, shareholders will not prefer retained earnings financing if information is only slightly asymmetric-as is generally the case with publicly traded firms subject to regular disclosure requirements. See Milton Harris \& Arthur Raviv, The Theory of Capital Structure, 46 J. Fin. 297, 306-11 (1991). In addition, even if information is asymmetric, shareholders will unambiguously prefer internal financing only if they assume managers are pursuing firm interests. Otherwise, monitoring concerns (and a desire to shift the risk of bad projects to others) may produce a shareholder preference for external financing. Finally, the impact of asymmetric information on shareholder preferences for retained earnings does not alter our claim that some managers still will benefit from the retained earnings trap created by the double tax. In addition to causing shareholders to prefer retained earnings to dividend distributions, the double tax reduces the rate of return that shareholders require of projects the firm finances with retained earnings to a point below that of the external projects the shareholder might invest in if the firm distributed the earnings. See infra Subsection IV.C.1.

103. See Adler, supra note 97 (discussing how managers sometimes use unsecured financing, with the attendant increase in creditor monitoring, to bond themselves to shareholders).

104. The empirical evidence generally supports the idea that, absent taxes, investors would prefer dividends over retained earnings. See BREALEY \& MYERS, supra note 96, at 385-86; Jean Crockett \& Irwin Friend, Dividend Policy in Perspective: Can Theory Explain Behavior, 70 Rev. ECON. \& STAT. 603, 611-12 (1988); Chinmoy Ghosh \& J. Randall Woolridge, An Analysis of Shareholder Reaction to Dividend Cuts and Omissions, 11 J. Fin. REs. 281, 292-93 (1988). But see Merton H. Miller \& Myron S. Scholes, Dividends and Taxes, $6 \mathrm{~J}$. Fin. ECON. 333, 333-42 (1978) (finding no investor preference for dividends even when taxes are taken into account).

105. The separation of ownership and control is a central feature of the American corporate system, but it by no means characterizes all advanced industrial financial regimes. In particular, financial intermediaries in both Germany and Japan hold extensive equity interests and are generally thought to exercise significant control over companies they own. Mark J. Roe, Some Differences in Corporate Structure in Germany, Japan, and the United States, 102 YALE L.J. 1927 (1993). Our thesis seems to imply 


\section{B. How the Double Tax Can Trap Earnings}

The double tax can reduce shareholder pressure to distribute dividends. ${ }^{106}$ Managers can more easily use retained earnings to finance new projects. ${ }^{107}$ The double tax may even cause shareholders to accept a lower pretax rate of return on internal firm investment projects than on external investment projects. This retained earnings trap, we argue, causes some managers to oppose integration and support the double tax. ${ }^{108}$

The double tax traps earnings only under certain conditions. Most importantly, the tax traps earnings when the Code imposes a higher tax on ordinary income earned by individuals than on corporate profits. ${ }^{109}$ Under this rate structure, the taxes imposed on profits that are retained and reinvested are lower than the taxes imposed on earnings distributed and reinvested by shareholders. Thus, under the double tax, shareholders benefit by leaving retained earnings in the corporation rather than receiving dividends. Shareholders therefore require a lower pretax rate of return for investments funded by retained earnings because these investments bear a lower tax burden.

that these countries should have an integrated tax system.

A cursory examination of foreign tax systems does tend to confirm the connection between double taxation and separated ownership and control. The economics and politics of integration, however, are so complex that we are reluctant to place much weight on simple comparisons. Extensive research is needed even to answer the apparently straightforward question of whether another country has an integrated system. The Treasury Department, for example, did not examine the Japanese system of integration in its recent report, because it believed that Japan had recently adopted a classical double tax. DEPARTMENT OF THE TREASURY, INTEGRATION, supra note 10, at 159. In fact, however, the Japanese changes simply substituted one system of partial integration for another. 5 DoING BUSINESS IN JAPAN pt. 10, at 4-5 (Zentaro Kitagawa ed., Supp. 1995). The incentive effects of another country's tax system require even more careful study. Germany, Britain, and France have partial integration systems that are structurally similar. Some observers, though, believe that, because of features such as different rate structures, the three systems encourage very different financial policies. See, e.g., MCLURE, supra note 10, at 51-69 (French and German systems encourage some earnings retention, while British system does not).

Control by financial intermediaries, moreover, may not be equivalent to direct control by beneficial owners. Control by intermediaries may simply shift the agency cost problem from the firm to the financial intermediary. Recent work suggests that financial intermediaries in other systems, notably the Japanese, are not exclusively, nor perhaps even primarily, occupied by monitoring on behalf of shareholders. See Ronald J. Gilson \& Mark J. Roe, Understanding The Japanese Keiretsu: Overlaps Between Corporate Governance and Industrial Organization, 102 YALE L.J. 871 (1993) (noting that intermediaries in part facilitate the production process).

This is only a brief sample of potential problems in making international comparisons. Only a detailed case study could demonstrate whether the experience of another country is consistent with our argument.

106. See infra note 124 (noting that most, but not all, scholars agree that double tax can trap earnings).

107. Indeed, in certain circumstances the double tax will cause shareholders to prefer that firms finance projects from retained earnings, rather than employing external financing, notwithstanding the deductibility of interest on debt. See AMERICAN LAW INST., INTEGRATION, supra note 8, at 28-33.

108. The double tax is not the only solution to the incompatible preferences problem. Managers have also lobbied successfully for legal rules that reduce, without eliminating, shareholder ability to monitor managers and pressure them to distribute earnings. See, e.g., Black, Shareholder Passivity, supra note 38, at 530-66; Mark J. Roe, A Political Theory of American Corporate Finance, 91 CoLUM. L. REV. 10, 19 (1991); Roberta Romano, The Political Economy of Takeover Statutes, 73 VA. L. REv. 111, 180-84 (1987).

109. The rates applicable to corporate income are found in I.R.C. $\S 11(b)$ (West 1995). The rates applicable to personal income are found in id. $\$ 1$. Dividends are defined by id. $\S 316$, and explicitly included in taxable personal income by $i d$. $\$ 61(\mathrm{a})(7)$. 


\begin{tabular}{||l|l|l||}
\hline & RETAINED EARNINGS & DIVIENDS \\
\hline YEAR 1 & $\$ 1000$ & $\$ 1000(1-.418)=\$ 582$ \\
\hline YEAR 2 & & \\
\hline PRETAX RETURN & $\$ 1000+\$ 100=\$ 1100$ & $\$ 582+\$ 58.2=\$ 640.20$ \\
\hline $\begin{array}{l}\text { RETURN AFTER } \\
\text { CORPORATE TAX }\end{array}$ & $\$ 1000+\$ 100(1-.35)=\$ 1065$ & N/A \\
\hline $\begin{array}{l}\text { RETURN AFTER } \\
\text { PERSONAL TAX }\end{array}$ & $\$ 1065(1-.418)=\$ 619.83$ & $\$ 582+\$ 58.2(1-.418)=$ \\
\hline TOTAL & $\$ 619.83$ & $\$ 615.90$ \\
\hline $\begin{array}{l}\text { PROFTT } \\
\text { (ON NET EARNINGS) }\end{array}$ & $\$ 37.83$ & $\$ 33.90$ \\
\hline \hline
\end{tabular}

TABLE 1.

This basic retained earnings trap can be illustrated with a simple example. ${ }^{110}$ Consider a firm with $\$ 1000$ of earnings per shareholder. Assume, for the sake of simplicity, that the rate of return on capital is $10 \%$ for both corporations and shareholders. ${ }^{111}$ The top corporate tax rate is $35 \%$, as it is at present. Assume that the individual tax rate is $41.8 \%$, the approximate marginal tax rate imposed on an average wealthy taxpayer. ${ }^{112}$ If the corporation retains the earnings and invests them, the net profit to the

110. For a more precise explanation of the retained earnings trap, consider a shareholder of a corporation that has $Y$ dollars of after-tax earnings. The corporation is deciding whether to retain the earnings for a project that eams the competitive return on corporate capital, $R$, or to distribute the funds to shareholders, who will invest the money outside the corporate sector, earning $r$. If the firm retains the earnings, all eamings will eventually be distributed to shareholders as dividends. The net annual return on these retained earnings will be $R(l-c)$, where $c$ is the corporate tax rate. This will compound for $n$ years, after which time it will be distributed as a dividend and taxed at the personal tax rate, $p$. Shareholders will have, after all taxes are paid: Retained Eamings $(I-p) Y[I+R(I-c)]^{n}$. If the corporation distributes the earnings immediately, the shareholder pays an immediate tax at the personal rate $p$ on the distribution, $Y$. The shareholder will reinvest the distribution, earning an after-tax return of $r(1-p)$. After $n$ years, the shareholder will have: Distributed Earnings $(1-p) Y[1+r(1-p)]^{n}$. Shareholders will prefer the policy that maximizes their expected wealth. If the expected rate of retum in the corporate sector equals that in the noncorporate sector $(R=r)$, and the corporate and personal tax rates are equal $(c=p)$, the shareholder's wealth after $y$ years will be the same whether earnings are retained or distributed: $(I-P) Y$ $\left[I+R(I-c) f^{n}=(I-p) Y[I+r(I-p)]^{n}\right.$. The double corporate tax accordingly will not affect the shareholder's preference for retained eamings over distributions. If the individual tax rate instead exceeds the corporate rate, the double tax traps retained eamings. The tax-induced benefit to the shareholder of retained eamings over dividends is an additional $(I-p) Y[r(p-c)]^{n}$ in year $n$. The shareholder, therefore, will prefer earnings retention to distribution. See AMERICAN LAW INST., INTEGRATION, supra note 8, at 28-33; SCHOLES \& WOLFSON, supra note 101, at 328-30; see also MCLURE, supra note 10, at 24.

111. The present example assumes that the rates of return in the corporate and noncorporate sectors are the same in order to isolate the effect of the double tax.

112. This estimation of the marginal personal rate is based on a base marginal rate of $36 \%$, plus the $3.6 \%$ surcharge imposed on wealthier taxpayers, plus $1.2 \%$ (which represents the loss of $\$ 30$ of itemized deductions per $\$ 1000$ earned), plus approximately $1 \%$ (which is the resulting loss of $2 \%$ of the taxpayer's personal deductions per $\$ 2500$ earned and assumes two personal deductions). 
shareholder in Year 2 will be $\$ 37.83$. If the firm distributes the earnings and the shareholder invests them, he will have a net profit of $\$ 33.90$.

Thus, in our example, the double tax imposes a penalty of $10.4 \%$ on shareholders who receive dividends rather than leaving their money in the corporation. ${ }^{113}$ This additional burden on dividend distributions increases the cost to shareholders of the additional monitoring from external financing. The double tax thus creates a retained earnings trap, thereby helping managers by reducing shareholder preference for dividend distributions. ${ }^{114}$ Moreover, the double tax lowers the rate of return shareholders require on internal funds. ${ }^{115}$ In our example, shareholders would prefer an internal project with a return just over $9 \%$ to an external project with a return of $10 \% .{ }^{116}$ The double tax thus enables managers to pursue investments that yield below-market rates of return. ${ }^{117}$

113. Net profit refers to the one-year profit on the shareholder's net retained earnings of $\$ 582$. The profit is calculated based on net retained earnings ( $\$ 1000-\$ 418$ in taxes), because it is assumed that, whether the earnings are distributed now or later, the shareholder will have to pay taxes on them at the personal rate of $41.8 \%$.

114. The discussion in the text implicitly assumes that, if the firm distributes earnings, it will not undertake the new corporate investment. However, the basic analysis is quite similar when the firm has determined to undertake a particular investment and is deciding whether to employ retained earnings instead of external funds. The double tax may cause shareholders to prefer that the firm pursue new investment using retained earnings rather than distributing the earnings and financing the project through either debt or new equity. Moreover, the circumstances where the double tax creates a preference for intemal financing are very similar to the circumstances where the tax traps retained earnings: Shareholders prefer internal financing if the corporate rate is less than the personal rate. To see this, consider a shareholder's wealth under these three alternative financial structures. If the interest rate on corporate borrowing equals the competitive rate of return, shareholder wealth will be:

$$
\begin{array}{ll}
\text { Retained Earnings: } & (I-p) Y[1+r(I-c)]^{y} \\
\text { Debt: } & (I-p) Y[1+r(I-p)]^{y} \\
\text { New Equity: } & (I-p) Y[1+r(I-c)(1-p)]^{p}
\end{array}
$$

When $c<p$, retained earnings clearly are preferable to the other solutions. See AMERICAN LAW INST., INTEGRATION, supra note 8, at 25-28. If, as is likely, the corporate and noncorporate rates of retum differ, then the shareholder's retums from retained earnings and debt are:

$$
\begin{array}{ll}
\text { Retained Earnings: } & (I-p) Y[I+R(I-c)]^{y} \\
\text { Debt: } & (I-p) Y[I+(R-r)(I-c)+r(I-p)\}^{y}
\end{array}
$$

If $R>r$, and $c>p$, then retained earnings are necessarily preferred to debt. Moreover, retained eamings may still be preferred to debt if $R<r$, provided $c>p$.

115. MASULIS, supra note 42, at 85; see also Ronald W. Masulis \& Brett Trueman, Corporate Investment and Dividend Decisions Under Differential Personal Taxation, 23 J. FIN. \& QUAN. ANALYSIS 369, 369-70 (1988) (discussing relationship between dividend payouts and real asset investment, given individual shareholders' tax situations and size of corporation's available internal funds).

116. The internal rate of return at which the shareholder would be indifferent between internal and external projects (assuming a 10\% rate of return on external projects) is the $R$ such that: $(.582)(1000)(1+$ $R(.65))=615.90 . R$ thus equals $9 \%$ in our example.

117. Specifically, under a classical double tax, managers deciding whether to engage in a particular investment project will ask whether the project will raise share values by as much as it reduces the after-tax dividend income of shareholders. Accordingly, managers will "undertake some investment projects which do not raise the firm's value by the project's full cost." Poterba \& Summers, supra note 79, at 270. 
In addition, the double tax may create a retained earnings trap even when the corporate tax rate is equal to or greater than the personal rate. First, the double tax may create a retained earnings trap if the pretax rate of return in the corporate sector exceeds that in the noncorporate sector. ${ }^{118}$ Moreover, the double tax is likely to cause corporate sector rates of return to exceed noncorporate sector rates of return. Equilibrium requires that the after-tax rates of return of the two sectors be equal. Accordingly, when the corporate sector is subject to a double tax but the noncorporate sector is not, the pretax rate of return on corporate sector investments should generally exceed that of the noncorporate sector. Thus, even if the personal rate and corporate rate are equal, shareholders will prefer that the firm retain earnings, rather than distribute them to shareholders to invest outside the corporate sector, because retention and distribution bear the same total tax burden but corporate investments earn a higher pretax rate of return. ${ }^{119}$

Second, even if the personal tax rate is below the corporate rate, the double tax will trap retained earnings if shareholders plan to reinvest dividend distributions in the corporate sector. ${ }^{120}$ In fact, many shareholders will reinvest in the corporate sector. ${ }^{121}$ In this situation, the "double tax" imposes a triple tax on earnings reinvested in another corporation. Earnings are taxed once on distribution; when reinvested in a corporation, the resulting profits are taxed again at the corporate level and a third time when distributed. Retained earnings, by contrast, are only taxed twice. The double tax thus traps some earnings that would be reinvested in the corporate sector even if the personal tax rate is less than the corporate rate. ${ }^{122}$

118. In this situation, the tax-induced benefit to the shareholder of retaining earnings rather than distributing them is $(I-p) Y[R(I-c)-r(I-p)]$. Indeed, the double tax may cause the shareholder to prefer earnings retention even if the pretax return in the corporate sector is less than the pretax return outside the corporate sector. In our example, the shareholder will prefer retained earnings if the corporate rate of return, $R$, exceeds $r[(1-p) /(I-c)]$, which is less than $r$, assuming $c<p$.

119. Driving this result is the fact that equilibrium rates of return may be based on initial investments of capital, where the noncorporate sector pays a single tax, whereas corporate shareholders investing dividends in the noncorporate sector still must pay the double tax on those distributions. ("Noncorporate sector" is used loosely here to refer to businesses not subject to the double tax.)

120. The standard analysis assumes that shareholders invest dividend distributions outside the corporate sector. See, e.g., AMERICAN LAW INST., INTEGRATION, supra note 8, at 28-33.

121. First, shareholders of publicly held firms often will be seeking passive liquid investments; most noncorporate investments are less liquid, and many require owners to be more actively involved in the business. Second, shareholders of publicly held firms may want to retain the limitation on liability associated with corporate investments. Third, an investor who has achieved the optimal balance of risk and return should not reinvest all dividends in Treasury securities, with their low risk and low return.

122. KLEIN \& COFFE, supra note 89 , at 372-73. Consider our previous example, but assume that the shareholder reinvests all distributed earnings within the corporate sector. For ease of comparison, we will assume that this second firm distributes all of its earnings (and the shareholder's initial investment) in the last period. Assuming a one-year investment horizon, this can be expressed algebraically as follows:

$$
\begin{array}{ll}
\text { Retained Earnings: } & (1-p) Y[1+R(1-c)] \\
\text { Distributed Earnings: } & (1-p) Y[1+R(1-c)(1-p)]
\end{array}
$$

The double tax thus traps eamings even if the personal tax rate is less than the corporate rate. 
The double tax therefore can bring shareholders' tastes closer to those of managers by increasing shareholder desire for internal financing and firm expansion. This benefit to managers would be lost in a system of pure passthrough taxation. Similarly, the partial integration plans that have been put before Congress also would eliminate-or even reverse-the retained earnings trap, increasing shareholder pressure for dividend payments. ${ }^{123}$ In the next section we examine whether the desire to trap earnings has in fact induced managers actively to support the double tax.

\section{Do Managers Support the Double Tax to Trap Earnings?}

Managers will not necessarily support the double tax simply because it traps earnings. A manager will oppose integration in order to keep the retained earnings trap only if the double tax traps earnings in his firm and he benefits from the trap. In this section, we argue that both criteria are met in only a relatively small number of cases. Although the double tax traps earnings in most firms, most managers do not benefit from the trap.

\section{Does the Double Tax Trap Earnings?}

Throughout the history of the income tax, the double tax has trapped the earnings of a significant number of firms. ${ }^{124}$ Earnings are trapped whenever

123. Although not all partial integration proposals would eliminate the retained earnings trap, those integration proposals that have been put before Congress would. The dividend exclusion method, which has been considered often, would tax all income at the corporate level but would permit taxpayers to exclude dividend income from their taxable income. Both retained and distributed earnings would therefore be taxed at statutory corporate rates. Such a plan would in general reduce the lock-in effect (although one can be designed that retains a lock-in effect). Two other partial integration methods that have been proposed as legislation, an imputation credit and a dividend deduction, are quite similar. Both systems would tax all corporate income at only one level. Like a pure integration system, both would tax distributed earnings at the personal rate. Both, however, would tax retained earnings at the corporate rate. The simplest versions of both systems (and the versions actually introduced) would have some element of double taxation. Retained earnings would be subject to a second level of tax-albeit a deferred one-at the time of sale. Even if corporate and personal income were taxed at the same rates, retained earnings would sometimes be taxed more heavily than dividends. Thus, both plans would reverse the retained earnings trap and encourage the distribution of profits.

124. The proposition that the double tax creates a retained earnings trap is widely asserted. See, e.g., AMERICAN LAW INST., INTEGRATION, supra note 8, at 28-33 (noting that classical double tax has historically favored retention of earnings); Levmore, supra note 15, at 257 (tax system encourages retention of earnings and therefore growth); Zolt, supra note 8, at 843-44; cf. Mark Campisano \& Roberta Romano, Recouping Losses: The Case for Full Loss Offsets, 76 Nw. U. L. REv. 709 (1981) (analyzing effect of loss offsets on firm growth). The question of whether the trap should induce managers to support double taxation has not been extensively examined, however. A few leading tax scholars have argued that the double tax does not create a retained earnings trap. See, e.g., KING, supra note 23, at 50-51, 108-110; Alan J. Auerbach, Debt, Equity, and the Taxation of Corporate Cash Flows, in DEBT, TAXES, AND CORPORATE RESTRUCTURING 91, 95 (John B. Shoven \& Joel Waldfogel eds., 1990); Alan J. Auerbach, Wealth Maximization and the Cost of Capital, 93 Q. J. EcoN. 433, 433-34 (1979); David Bradford, The Incidence and Allocation Effects of a Tax on Corporate Distributions, 15 J. PUB. ECON. 1 (1981); Miller \& Scholes, supra note 104, at 360-61. These claims have been extensively analyzed and rejected by others. See, e.g., Martin Feldstein \& Jerry Green, Why Do Companies Pay Dividends?, 73 AMER. ECON. REV. 17, 18-19 
the personal tax rate exceeds the corporate rate, and the trap increases as the gap between the personal and corporate rates widens. ${ }^{125}$ The history of the statutory rate structure suggests that the U.S. tax code has trapped earnings during some periods, but not others. Between 1939 and 1986, top personal rates exceeded corporate rates, and the percentage of taxpayers whose marginal rates exceeded the marginal corporate rate steadily increased. ${ }^{126}$ Since 1986 , however, the corporate and individual rates have been much closer together, and until 1993, the corporate rate exceeded the top individual rate.

The statutory rate structure, however, is not an accurate guide to the retained-earnings-trap effect. The retained earnings trap depends not on the relative statutory tax rates on personal and corporate income, but on the relative effective marginal rates. Many firms face effective marginal tax rates that are substantially below the statutory corporate rate. The Internal Revenue Code provides a variety of tax preferences, such as ACRS, that lower the effective tax rate on new capital far below the statutory rate. Under current law, tax preferences are not passed through to shareholders, and so they lower the corporate rate relative to the personal rate. ${ }^{127}$ Although the Code imposes a nominally uniform rate on corporate income, the incidence of preferences varies widely between corporations. ${ }^{128}$ The uneven distribution of preferences means that different sectors face different effective tax rates. Even after 1986, many firms faced effective marginal tax rates that were considerably lower than the personal tax rate; thus, their earnings were trapped. Therefore, even after 1986, managers of low-tax-rate firms should have continued to favor the

(1983); Poterba \& Summers, supra note 79, at 230, 240. Moreover, the hypothesis that the current tax system does impose a double tax on corporate income-and specifically a marginal tax on dividends-is supported by the available empirical evidence. Id. at 274-75; see William M. Gentry, Taxes, Financial Decisions and Organizational Form: Evidence from Publicly Traded Partnerships, 53 J. PUB. ECON. 223 (1994) (claiming that comparison of corporations to publicly traded limited partnerships subject to partnership taxation suggests that double taxation of corporate income reduces dividend payments).

125. This is a sufficient, but not a necessary, condition for the double tax to trap retained earnings. See supra text accompanying notes 109-23.

126. In 1961, about $90 \%$ of all returns were taxed at a marginal rate below $22 \%$; by 1979 , that marginal rate had risen to a high of $32 \%$. During this time, the top personal rate fluctuated between $76 \%$ and $90 \%$ while the corporate rate remained around $45 \%$.

127. To see how, suppose a corporation earns $Y$ in net income. From this the corporation is permitted to deduct tax preferences in the amount $a$, leaving taxable income of $Y-a$ and after-tax income of $Y$ $(Y-a) c$. The tax preference $a$ could be regarded in two ways. The preference amount $a$ could be seen as a contribution to corporate capital. If after-tax income were then distributed to shareholders, they would exclude $a$ from their income as a return of capital. Their total taxable income would be $Y-(Y-a) c-a$, and the preference would have been extended to the shareholder level. In fact, however, $a$ is not treated as a contribution to capital at the corporate level, but instead increases earnings and profits. The entire amount distributed to shareholders is therefore taxable. Under current law, then, tax preferences reduce the tax rate on corporate-level income, but leave the tax rate on shareholder-level income unchanged.

128. Some items, such as percentage depletion, are in principle available only to firms in certain industries. Other preferences, such as ACRS, are important only to firms with significant capital requirements. Moreover, the depreciation allowances accorded to various assets differ in generosity, creating different effective tax rates even among capital-intensive firms. Other tax preferences, such as the completed contract and installment methods of accounting, are theoretically available generally, but are in practice useful only to firms for which certain business practices make sense. 
double tax. In fact, after 1986, a few managers did continue explicitly to oppose integration because of the retained earnings trap. ${ }^{129}$

The statutory bracket amount is likewise an incomplete guide to the tax rate that individuals face. Effective individual rates vary from person to person and, for any given individual, between types of income. Some of these variations increase the lock-in effect. Earnings retained by the firm may not ultimately be distributed as dividends and taxed as ordinary income. Rather, shareholders may obtain their earnings by selling their shares and receiving their portion of the earnings as capital gains. The effective tax rate imposed on earnings realized as capital gains will often be less than the rate imposed on earnings received as ordinary income for several reasons: The maximum statutory rate imposed on capital gains is only $28 \%$; capital gains, unlike dividends, can be used to offset capital losses; and shareholders can avoid all capital gains taxation by holding shares until death. ${ }^{130}$ The lower tax on retained earnings increases the lock-in effect.

The effective rate structure of the U.S. tax system therefore suggests that many firms have faced a retained earnings trap even after 1986. Statutory rates can also overstate the retained earnings trap, however. Effective rates suggest that some firms did not face a trap even before 1986. Some firms face unusually high effective corporate tax rates. Such high rates can result, for example, from high taxes on foreign income. Perhaps more importantly, not all taxpayers face the top statutory rate assumed by the previous analysis. Topbracket taxpayers hold a disproportionate share of common stock ${ }^{131}$ but far from all of it. Indeed, with the growth of pension funds, tax-exempt organizations hold significant amounts ${ }^{132}$ of corporate equity. Low-tax-

129. See R. Eliot Rosen, Treasury's Corporate Integration Study Back on Track, 49 TAX NOTES 956, 956 (1990). Many analysts had expected that managerial support for integration would increase after 1986. Comprehensive Analysis, supra note 94, at G-5 (quoting Assistant Secretary for Tax Policy Kenneth Gideon). Corporate support for integration did increase, but not substantially. See Leveraged Buyouts, Daily Rep. for Executives (BNA) No. 93, at G-6 (May 16, 1987). Since companies' opposition had been based on concerns about the expense of windfall profits, the 1986 Act did nothing to change their perspective.

130. See I.R.C. \& 1014 (West 1995). Accordingly, a shareholder who plans to hold most of his assets until death can avoid a substantial portion of the capital gains tax imposed on those assets. See, e.g., JANE G. Gravelle, Congressional Research Service, Library of Congress, Corporate Tax INTEGRATION: ISSUES AND OPTIONS 5-8 (1991); SCHOLES \& WOLFSON, supra note 101, at 75 n.24.

131. Historically, most of the stock held in the personal sector has been held by the top $1 \%$ (or $1 \frac{1}{2} \%$ ) of adult wealth holders. JAMES BURK, VALUES IN THE MARKETPLACE: THE AMERICAN STOCK MARKET UNDER FEDERAL SECURITIES LAW 164 (1988) (presenting data on holdings between 1922 and 1972). Moreover, the top $1 \%$ of taxpayers have received almost $50 \%$ of corporate dividends. See Griffith, supra note 9, at 717-22 (analyzing relative preferences for corporate equity of top- and lower-bracket taxpayers). See generally SCHOLES \& WOLFSON, supra note 101, at 63 (discussing complications in determining shareholder tax rate).

132. In 1993, pension funds owned approximately $31.3 \%$ of all outstanding U.S. equities; mutual funds (which generally also are tax exempt) owned another $10.3 \%$. MARK ROE, STRONG MANAGERS, WEAK OWNERS 125 (1994). Institutional investors as a group owned about $43.5 \%$ of the total equities outstanding in the United States as of the end of 1989. RiCHARD W. JENNINGS ET AL., SECURITIES REGULATION: CASES AND MATERIALS 16-17 (7th ed. 1992). For a discussion of institutional investors' ability to infiuence corporate tax policy, see infra Section V.A. 
bracket shareholders are more likely than high-bracket shareholders to want dividend distributions. These different preferences for dividends produce a "clientele effect": Each corporation will tend to attract shareholders with similar characteristics who prefer a similar payout ratio. ${ }^{133}$ To attract shareholders, some firms must appeal to lower-bracket investors with a strong preference for dividends, ${ }^{134}$ while others appeal to high-bracket investors who prefer retained earnings. ${ }^{135}$ Managers of firms with a low-bracket clientele will not be motivated by the trap to support double taxation. For them, the double tax not only fails to trap earnings, it also raises their cost of capital and can even create pressure to distribute earnings. Accordingly, managers of such firms should favor integration. ${ }^{136}$

\section{Why Most Managers Will Not Support the Double Tax}

Even managers of firms that do face a retained earnings trap will not necessarily favor double taxation. Managers support the double tax only if their interests diverge from those of shareholders. This divergence will be common in publicly held firms. Most corporations, however, are closely held, and the manager-owners of these firms have a direct stake in firm projects. They thus have every incentive to maximize firm profits and little or no incentive to pursue non-profit-maximizing expansionist policies. ${ }^{137}$

Even many managers of publicly held firms should not support the double tax. For many managers, the costs of the double tax will exceed the benefits of the retained earnings trap. Managers benefit from the double tax if they can finance new projects with retained earnings; they do not benefit if their firm's investment projects exceed available earnings, so that external financing is required anyway. The quest for new capital constrains managers' ability to

133. See Miller \& Modigliani, supra note 93, at 431-32 (discussing possibility of "clientele" effect). See generally J. FRED WESTON \& THOMAS E. COPELAND, MANAGERIAL FINANCE 698-701 (9th ed. 1992) (discussing clientele effect).

134. A low-bracket shareholder's preference for dividends will depend in part on whether he plans to reinvest in the corporate sector. See supra text accompanying notes 120-23.

135. See BREALEY \& MYERS, supra note 96, at 388-89. Firms with high effective tax rates-which do not benefit from retained earnings-may also be the firms that pay high dividends to attract shareholders with a strong preference for dividends.

136. Although the double tax may create a retained earnings trap even if the personal rate is less than the corporate rate, see supra notes 118-23 and accompanying text, the double tax will not trap retained earnings if the personal rate is sufficiently below the corporate rate. Thus, the double tax probably does not trap earnings of firms with very low-bracket marginal shareholders, such as pension plans.

137. Similarly, managers of firms with concentrated ownership have less reason than others to support the double tax in the quest for retained earnings. When control is concentrated, shareholders are better able to monitor managers. See Demsetz \& Lehn, supra note 87 , at $1158-60$. When shareholders can monitor managers effectively, managers have less to gain from the retained earnings trap because shareholders can oversee their use of these earnings. Accordingly, these managers have less reason to support the double tax, because the tax increases the cost of external capital and gives them little benefit in the form of reduced monitoring. The tax may confer some benefit on these managers, however, because it does increase shareholders' preference for firm expansion relative to external investment projects. 
employ internal funds on suboptimal projects. Firms earning suboptimal returns may have difficulty obtaining additional equity, except at a significant discount. Firms with suboptimal projects may also find debt financing more expensive, since their risk of insolvency is higher. Accordingly, the double tax does not enable these managers to avoid the monitoring of new investments by the capital markets.

Moreover, the double tax may make outside financing of new investments more expensive. Only interest payments, not dividends, are deductible. A double tax on returns to corporate capital thus increases the cost of externally financed new investments to the extent that those investments must be financed with new equity rather than new debt. ${ }^{138}$

Finally, managers of firms dependent on external financing may find that the double tax exacerbates a conflict with shareholders that would exist even in the absence of taxes. The deductibility of interest on corporate debt obligations increases shareholder pressure to debt finance these additional projects. Debt creates the risk of default and bankruptcy. Consequently, riskneutral shareholders have a greater taste for debt financing than do risk-averse managers. ${ }^{139}$

The importance of each of these factors will vary widely between firms. Firms differ greatly in their ability to issue debt. Large, mature firms can readily obtain debt financing at competitive rates. They face little risk of

138. Even some investments financed with debt may effectively bear the double tax. For example, firms with significant nondebt tax shields, such as accelerations depreciation, depreciation allowances, and investment and foreign tax credits, may not be able to utilize fully their interest deductions. At some point, these firms may find that any external financing, debt or equity, will be subject to the full double tax. This significantly affects the cost to the firm of this financing. See Harry DeAngelo \& Ronald W. Masulis, Optimal Capital Structure Under Corporate and Personal Taxation, 8 J. Fin. ECON. 3, 7-10 (1980). Even those firms that can easily obtain debt financing cannot employ it to eliminate the burden of the double tax on equity. When the firm's rate of return exceeds the interest rate on debt-which is the very situation where debt is particularly attractive to equity-equity bears the full double tax on its share of the return. SCHOLES \& WOLFSON, supra note 101 , at 377 .

139. In addition to the tax benefits of leverage, shareholders may benefit from increased leverage because they receive all the resulting residual profit (thus increasing the expected earnings stream per share), while debt holders bear part of the risk. Easterbrook, supra note 96, at 653; see KLEIN \& COFFEE, supra note 89, at 7-11. See generally BREALEY \& MYERS, supra note 96, at 404-05 (discussing effects of leverage on returns). Shareholders may also prefer debt because the transaction costs associated with large debt issues, particularly issues of nonconvertible debt, are substantially lower than those associated with large equity issues. See MASULis, supra note 42, at 6-7 (noting that floatation costs are lower for nonconvertible debt issues than for equity issues or convertible debt issues, both for issues under $\$ 1$ million and for issues over $\$ 100$ million). In addition, newly issued equity generally is subject to a substantial discount and may cause a decline in existing share prices. See BREALEY \& MYERS, supra note 96, at 345, $349 \&$ n.21. Finally, shareholders will prefer certain types of debt financing to issuing new equity because certain types of debt financing, for example bank loans, appear to be associated with more ongoing monitoring. See Eugene F. Fama, What's Different About Banks?, 15 J. MONETARY ECON. 29, 37-38 (1985) (suggesting that banks can monitor loans to depositors at lower costs than other lenders can); Scott L. Lummer \& John J. McConnell, Further Evidence on the Bank Lending Process and the Capital-Market Response to Bank Loan Agreements, 25 J. FIN. ECON. 99 (1989) (discussing empirical evidence supporting view that banks gain information about clients over time and transmit it to capital markets through loan renewal process); see also Laura Lin, The Information Content of a Bank's Involvement in Private Workouts, 3 GEO. MASON IND. L. REV. 97, 100, 106-18 (1994) (examining role of banks as well-informed monitors in lessening problem of imperfect information of other creditors in private workouts). 
insolvency because of their well-established earnings streams and substantial physical assets. ${ }^{140}$ Debt financing, however, substantially increases the risk of insolvency for emerging firms, undiversified firms, firms with highly variable income streams, and firms with few tangible assets. ${ }^{141}$ Managers of such companies are therefore unlikely to support the double tax.

A given level of debt will also subject different firms to different levels of monitoring. Managers of firms with substantial physical assets can avoid much of the monitoring associated with debt by having their firms issue secured debt. Secured credit enables the creditor to evaluate only the value of the collateral, not the value of the firm as a going concern. ${ }^{142}$ Companies without much physical capital can obtain debt only by agreeing to significant levels of monitoring. For managers of these firms, therefore, the double tax only exacerbates shareholder pressure to assume high levels of debt and submit to outside monitoring by creditors.

\section{Evidence}

The historical pattern of effective tax rates ${ }^{143}$ suggests that some firms have faced a retained earnings trap for most of the last fifty years. Firms in this position have produced a small but influential group of managers who have opposed integration in order to preserve the retained earnings trap.

These managers have expressed concerns about pressure to pay dividends from the time the first integration measures were introduced by Secretary Simon and Representative Ullman. ${ }^{144}$ Each successive iteration of the 1986

140. See Nevins D. Baxter, Leverage, Risk of Ruin and the Cost of Capital, 22 J. Fin. 395, 402 (1967).

141. See Knoll, supra note 63, at 1491-97.

142. See Adler, supra note 97, at 75, 82-83 (noting that secured credit saves evaluation and monitoring resources); F.H. Buckley, The Bankruptcy Priority Puzzle, 72 VA. L. REv. 1393, 1421-26, 1439-46 (1986) (same); Thomas H. Jackson \& Anthony T. Kronman, Secured Financing and Priorities among Creditors, 88 YALE L.J. 1143, 1153 (1979) (same); Levmore, supra note 97, at 55-57 (same); see also George G. Triantis, Secured Debt under Conditions of Imperfect Information, 21 J. LEGAL STUD. 225, 249-55 (1992) (discussing security as mechanism for mitigating information asymmetries).

143. The history of integration efforts confirms that effective tax rates, not statutory rates, determine the size of the retained earnings trap. Between 1986 and 1993, the change in statutory rates implied a reversal of the lock-in effect, and a corresponding surge in support for integration. However, support for integration after 1986 continued to come from the same firms and organizations as before, such as firms in highly taxed industries, the National Association of Manufacturers, and the American Council for Capital Formation. See Fran Hawthorne, Would Cutting the Dividend Tax Really Help?, INSTITUTIONAL INVESTOR, Aug. 1990, at 73 (quoting MCl's executive vice president that "double taxation [of corporate dividends] has no economic justification or rationale"); Pullen, supra note 13, at 12; Taxleads, Daily Rep. for Executives (BNA) No. 131, at H-1 (July 9, 1990). These groups still placed a much lower priority on integration than on other reform measures. See Levin, supra note 76, at 49. Their principal motive for giving less than full support for integration had not been a desire to protect the retained earnings trap but a concern-left unchanged by the 1986 reforms-about windfalls.

144. See Jonas, supra note 19, at 38; Policies to Spur Investment and Trade, BUS. WEEK, June 30, 1980 , at 127, 130 [hereinafter Policies]. Both Representative Ullman and Secretary Simon stressed that their proposals would increase the tax costs of retaining earnings. Finance Hearings, supra note 19, at 71 (testimony of William Simon, Secretary of the Treasury); 124 CONG. REC. 2132 (1978) (statement of Rep. Ullman). Some believe that managerial desire to trap earnings first surfaced in the battle over the 1936 
reform bill reduced the amount of integration proposed, and the final version that emerged from conference contained none at all. Many observers believe that the behind-the-scenes intervention of the Business Roundtable killed the 1986 integration measure. ${ }^{145}$ The Roundtable was apparently motivated by opposition to integration, rather than by fear that the price of integration would be excessive. ${ }^{146}$ Managerial desire to preserve the earnings trap was expressed in the response to the recent Treasury integration study. For the corporate community to support integration, one executive said that "corporate managers' decisions to retain or distribute earnings should not be unduly burdened."147

An influential segment of managers clearly wishes to trap earnings. At the same time, most managers do not seem to regard the retained earnings trap as a sufficient reason to oppose integration, and managers whose fear of excessive debt more than offsets any desire for the retained earnings trap actually support it. During congressional hearings on both the Simon and Ulman proposals, managers who testified-always in favor of integration-invariably gave as their principal reason the problem of excessive leverage. ${ }^{148}$ The 1986 letters supporting integration ${ }^{149}$ stressed the problems associated with the preference for debt, especially the problem of bankruptcy costs. Since the 1986 reforms, managers who support integration have continued to cite their fear of excessive leverage ${ }^{150}$ and difficulty obtaining debt. ${ }^{151}$

Revenue Act. The Act eliminated the personal deduction for dividends received, see Revenue Act of 1936, ch. $690, \S 25$, Pub. L. No. 74-740, 49 Stat. 1648, $1661-62$ (compare with prior § 25), provided corporations with a deduction for dividends paid, see id. $\$ 27$, and augmented the normal corporate tax with a tax on undistributed corporate profits, see id. \$14(b). The tax was eliminated altogether in 1939. See Revenue Act of 1939 , ch. 247 , § 201, Pub. L. No. 76-155, 53 Stat. 862, 863-64. Some policy analysts supported the tax because they hoped that it would create pressure to pay dividends, and managers may have opposed the tax because of the pressure to pay out earnings. See Mark J. Roe, Political Elements in the Creation of a Mutual Fund Industry, 139 U. PA. L. REv. 1469, 1496-98 (1991). However, policy analysts had other reasons to support the tax, such as a Keynesian desire to stimulate consumption, and managers had other reasons to oppose it, including the overall increase it produced in the tax burden on corporations. SIDNEY RATNER, TAXATION AND DEMOCRACY IN AMERICA 472-74 (Science ed., Wiley \& Sons 1967) (1942); see also Roe, supra, at 1497 (discussing supporters' managerial discipline and increased consumer spending rationales).

145. Saunders, supra note 65 , at 192 . Yet even the Business Roundtable at one point endorsed a dividend deduction. See Policies, supra note 144, at 131.

146. The Roundtable evidently preferred the version of reform that passed, which included significant cuts in ACRS, to a version that, identical in all other respects, also provided for integration.

147. Rosen, supra note 129, at 956 (paraphrasing Bob Mattson of IBM).

148. This was true of the Simon proposal hearings. See Finance Hearings, supra note 19, at 389, 391 (statement of George S. Koch, Chairman, Federal Finance Committee, Council of State Chambers of Commerce); id. at 1257, 1271 (statement of Charles W. Stewart, President, Machinery and Allied Products Institute); id. at 1291, 1301-02 (statement of Malcolm R. Lovell, Jr., President, Rubber Manufacturers Association); id. at 1335, 1344 (statement of Norma Pace, Senior Vice President, American Paper Institute). It was likewise true of the Ullman hearings. See House Hearings, supra note 81, at 6064-75, 6069-70 (statement of Roland M. Bixler, National Association of Manufacturers); id. at 6110-11 (statement of William S. Cashel, Vice Chairman and Chief Financial Officer, AT\&T); id. at 6111-14 (statement of Henry L. Duncombe, Jr., Vice President and Chief Economist, GM).

149. See supra note 72.

150. See Hawthorne, supra note 143 , at 73. 


\section{IMPLICATIONS FOR REFORM}

Integration is more likely to succeed if reformers have at least one major interest group as an ally. ${ }^{152}$ To this end, we propose that reformers adopt a three-part strategy. First, they should support corporate governance proposals that empower shareholders. Second, they should consider endorsing plans that make integration more attractive to managers. Finally, reformers should deny support to proposals that enable a select group of firms to avoid the double tax, as this would reduce the political pressure for integration of corporate sector taxes.

\section{A. Shareholders}

Shareholders have never played an active role in the debates on corporate taxation. This silence results largely from their lack of effective representation. Shareholders typically are too dispersed to exert significant control over corporate investment decisions or to lobby Congress directly. ${ }^{153}$ Even large shareholders have seldom lobbied Congress on behalf of shareholders generally. As Mark Roe and others have persuasively argued, the financial intermediaries that might voice shareholder concerns have been discouraged from participating in political debate. ${ }^{154}$ Nor has the recent growth of pension funds provided an effective vehicle for the expression of shareholder interests. Although pension funds, which are tax exempt, would unambiguously benefit from many forms of integration, ${ }^{155}$ they cannot lobby actively for integration.

151. In a 1990 survey, electronics industry executives expressed disapproval of double taxation. Not coincidentally, executives reported a need for massive amounts of new capital and expected to use primarily equity. Bruce C.P. Rayner, How U.S. Electronics CEOs Will Address the New Competitive Priorities, ELECTRONIC BUS., Mar. 19, 1990, at 34-35.

152. Not all laws can be explained solely by interest group politics. Legislators do act in the public interest, and their efforts do sometimes overcome the obstacles of special interest groups. See generally Joseph P. Kalt \& Mark A. Zupan, Capture and Ideology in the Economic Theory of Politics, 74 AM. EcoN. REV. 279 (1984) (exploring significance of public interest objectives in economic policymaking). Nonetheless, a wise legislator will consider opportunities to enlist the support, and minimize the opposition, of interest groups.

153. See generally Jensen \& Meckling, supra note 39, at 308-10, 356 (discussing positive aspects of agency cost theory with respect to relations between managers and outside debt and equity holders).

154. See Roe, supra note 144, at 1471-78. See generally ROE, supra note 132 (discussing interaction between politics and corporate governance). Most importantly, various laws combine to inhibit institutional investors from obtaining sufficient control of individual corporations to affect firm lobbying. See, e.g., id. at 51-146, 223 (providing historical data indicating that institutional investors own shares in small, unconcentrated blocks and that various laws discourage institutions from exerting control); Black, Agents, supra note 38, at 822-24 (detailing legal obstacles to institutional shareholder action); Roe, supra note 108, at 16-31 (detailing laws that impede institutions from either obtaining controlling position in any given firm or combining with other institutions to exert control). But cf. Ethan G. Stone, Note, Must We Teach Abstinence? Pensions' Relationship Investments and the Lessons of Fiduciary Duty, 94 COLUM. L. REV. 2222 (1994) (arguing that ERISA fiduciary duties are not impediment to relationship investing).

155. Tax-exempt institutions, however, would derive little benefit from dividend-exclusion integration because currently the dividends they receive are not taxable. Yet dividend-exclusion integration is the version that is particularly attractive to individual shareholders. Rational shareholders prefer dividend 
The Department of Labor interprets the rules governing the fiduciary obligations of pension trustees quite strictly ${ }^{156}$ and would strenuously object to significant lobbying expenditures. In addition, private pension fund managers are hired by the firm's management and thus are reluctant to lobby for reforms that management does not support. ${ }^{157}$ Finally, because pension funds are tax exempt, they are unlikely to support the form of integration most likely to generate public support-dividend-exclusion plans. ${ }^{158}$

In the short run, shareholders are unlikely to exert effective pressure for integration. ${ }^{159}$ Still, tax reformers hoping for integration should support policies to increase shareholders' independent political power. The political voice of shareholders could be strengthened by many of the measures proposed by Mark Roe, ${ }^{160}$ Bernard Black, ${ }^{161}$ and others ${ }^{162}$ to increase shareholder influence over internal corporate governance. These reforms include permitting political lobbying by pension funds; reducing restrictions on ownership concentration such as the Glass-Steagall Act; ${ }^{163}$ and permitting the easy

exclusion because it eliminates the retained earnings trap. Shareholders, whether perfectly informed and rational or otherwise, also may prefer dividend-exclusion integration to integration plans that reduce corporate-level taxes because they believe that they do not bear the corporate-level tax. Shareholders thus would prefer dividend exclusion because it directly reduces the taxes they pay, whereas those plans that reduce the corporate-level tax do not.

156. ERISA provides that "a fiduciary shall discharge his duties with respect to a plan solely in the interest of the participants and beneficiaries and (A) for the exclusive purpose of (i) providing benefits to participants and their beneficiaries; and (ii) defraying reasonable expenses of the plan." 29 U.S.C. § 1104(a) (1988). The Department of Labor has construed this requirement narrowly to exclude all but the most indispensable costs of a plan. Letter from Elliot I. Daniel, Associate Director for Regulations and Interpretations, Department of Labor, Pension \& Welfare Benefit Programs, to Kirk F. Maldonado (Mar. 2, 1987), available in LEXIS, Fedtax Library, ERISA file (characterizing many potential plan expenses as nondeductible settlor expenses). No authority deals directly with the question of lobbying, but, in the words of a senior Department of Labor official, "it would be hard to imagine circumstances in which lobbying would be considered a reasonable expense of the plan." Telephone Conversation with Bette Briggs, Division Chief, Fiduciary Interpretations and Regulations, Pension Benefits and Welfare Administration (Oct. 19, 1995).

157. See John C. Coffee, Jr., Liquidity Versus Control: The Institutional Investor as Corporate Monitor, 91 COLUM. L. REV. 1277, 1283 n.21, 1364-65 (1991); Edward B. Rock, The Logic and (Uncertain) Significance of Institutional Shareholder Activism, 79 GEO. L.J. 445, 469 \& n.80 (1991); Roe, supra note 108, at 24-25; see also Stone, supra note 154, at 2234 n.62 (noting problem that ERISA allows corporate management to control the investment of its workers' pension funds).

158. See supra Section II.D.

159. Cf. Tax Legislation: JCT Chief Pearlman Says Possibility of Major Tax Bill in 1990 is Unclear, Daily Rep. for Executives (BNA) No. 56, at G-1 (Mar. 22, 1990) (paraphrasing Ronald Pearlman, Chief of Staff for the Joint Committee on Taxation, as saying that "the future of the integration effort depends not only on revenue considerations but also on the interest of the business community").

160. See, e.g., Roe, supra note 108, at 17-31 (arguing for concentrated institutional ownership); Roe, supra note 144, at 1470-71 (suggesting that mutual funds concentrate shareholder power and provide valuable checks on management).

161. See, e.g., Black, Agents, supra note 38, at 815-16 (proposing limited role for several institutions to collectively influence corporate control); Black, Shareholder Passivity, supra note 38, at 523-25 (noting that coordinated voting among institutions and scale economies are incentives for institutions to become informed voters and monitor managers).

162. See, e.g., Alfred F. Conrad, Beyond Managerialism: Investor Capitalism?, 22 U. MiCH. J.L. REF. $117,163-67$ (1988) (arguing institutional investors will enhance profitability and curb managerial compensation expenses).

163. The current rules governing deductibility of debt and the current structure of debt ownership 
coordination of shareholder efforts now restricted by laws such as the Williams Act. ${ }^{164}$

\section{B. Managers}

Absent significant change in corporate governance laws, tax reformers cannot rely on shareholder pressure for integration. For integration to succeed, therefore, reformers will probably need the support of the only interest group with the ability and the inclination to lobby Congress on this issue: corporate managers.

Reformers can gain managerial support for integration by advancing integration plans that serve managers' interests. Most managers of publicly held firms are not opposed to integration in principle. Rather, they have little enthusiasm for tax reforms, such as conventional integration schemes, that provide windfalls to old capital. But windfalls are not an inevitable consequence of all integration plans. In particular, Congress might minimize windfalls by implementing integration in stages, as suggested by some integration proponents. ${ }^{165}$ Phase-in would concentrate the tax benefits from integration on new investments. Most managers thus should support such a proposal. ${ }^{165}$

Phased-in integration also makes sense from a policy perspective. Tax analysts are perhaps even less enthusiastic than managers about windfalls, since they, like managers, prefer measures that stimulate new investment. Phased-in integration could also generate considerable popular support. The public is especially receptive to tax subsidies such as ACRS that stimulate new

suggest that repealing the Glass-Steagall Act might promote integration. One puzzle for political analysts of the tax code is that dividends are not deductible whereas interest payments on debt are. There are reasons to question whether this is consistent with managers' interests, since managers generally are assumed to prefer equity over debt. Managers are not the only powerful political force affecting the tax treatment of debt, however. Banks and other financial institutions can, and do, own significant amounts of debt. Moreover, banks are well organized and effective as lobbyists. See David A. Skeel, Jr., Markets, Courts, and the Brave New World of Bankruptcy Theory, 1993 Wis. L. REV. 465, 497. To the extent that pressure from these well-organized, powerful institutional players explains, at least in part, why debt payments are subject to a single-level tax, it suggests that enabling banks to own equity may further the cause of integration. But see Adler, supra note 21, at 346 (offering populist explanation for interest deduction).

164. The Williams Act of 1968, which (among other things) regulates activities by owners of more than $5 \%$ of certain classes of securities, amends the Securities Exchange Act of 1934 and is codified at 15 U.S.C. §§ $78 l-n$ (1994).

165. The most systematic proposal to eliminate windfalls from integration is articulated in AMERICAN LAW INST., REPORTER'S STUDY DRAFT, supra note 17, at 54-101. That proposal, written by Professor William $\mathrm{D}$. Andrews, provides an elegant method for granting integration treatment only to new equity. Other proposals would simply phase in integration over time. These plans would provide some windfalls to capital but would be easier to administer. See AMERICAN LAW INST., INTEGRATION, supra note 8, at 205-22; DEPARTMENT OF THE TREASURY, INTEGRATION, supra note 10, at 89-92.

166. One executive who supported the 1986 integration proposal specifically endorsed phase-in to prevent windfalls and revenue loss. Companies Support Fifty Percent Dividends Paid Deduction, TAX Notes TODAY, May 14, 1985, at 86 (citing letter from Thomas M. Garvin, President of Keebler Co.). 
investments, and thus create jobs. ${ }^{167}$ Indeed, phased-in integration should generate even more public support than measures, such as ACRS, that benefit only physical capital and thus encourage firms to employ capital rather than labor. In contrast, phased-in integration would benefit all forms of new investment, including labor. Good policy often makes bad politics, but the two in this case may coincide. We therefore believe that reformers should focus their efforts on these phased-in integration schemes.

While many managers will support an integration plan as long as it concentrates its tax benefits on new capital, confining the benefits of integration to new capital will not win the support of all managers. Managers who benefit from the retained earnings trap may oppose even phased-in integration plans if those plans would reduce the trap. Whether an integration plan that favors new investments could succeed despite this opposition is an open question. The group of managers who benefits on net from the retained earnings trap is relatively small. Nevertheless, this group includes managers of some very large and established firms. Reformers may find that this group is simply too influential to challenge, in which case they should consider supporting integration plans that would trap earnings. These integration plans would, it is true, fail to remove one of the principal inefficiencies associated with the double tax, the retained earnings trap. ${ }^{168}$ Nonetheless, these plans would reduce or eliminate two other problems: the excess tax burden on the corporate sector and the bias towards debt financing. ${ }^{169}$ Half a loaf may be better than none, and so reformers might find it necessary to support integration plans that do not eliminate the retained earnings trap.

Reformers who decide to preserve the retained earnings trap should be alert to two issues in designing integration plans. First, earnings are more likely to be trapped if preferences are limited to the corporate level of tax. The simplest integration systems tend to equalize the personal and corporate rates because they pass preferences through to shareholders. However, some integration plans deny shareholders the benefits of preferences, ${ }^{170}$ thereby raising the personal rate relative to the corporate rate and thus increasing the lock-in effect. ${ }^{171}$ Second, many early integration proposals would push out

167. See infra Appendix B, Table B.3.

168. Some observers may see a silver lining to this cloud. Partial integration proposals that retain the corporate-level tax may be superior to pure pass-through taxation in some circumstances in that the entitylevel tax may reduce interinvestor conflicts and also certain manager-investor agency costs. See Kanda \& Levmore, supra note 15, at 230; Joseph A. Snoe, The Entity Tax and Corporate Integration: An Agency Cost Analysis and a Call for a Deferred Distributions Tax, 48 U. MIAMI L. REV. 1, 7-20 (1993).

169. Whether tax reformers should support integration plans that do not eliminate the retained earnings trap depends in part on the significance of the burden (if any) that the double tax imposes on the corporate sector, aside from the burden imposed by the retained earnings trap.

170. This is accomplished by a surtax on previously untaxed preference income at the time of distribution, either at the corporate or individual level.

171. Without preference pass-through, even a dividend exclusion plan can lock in earnings. The dividend-exclusion method would tax all income at the corporate level but would permit taxpayers to exclude dividend income from their taxable income. Both retained and distributed earnings would therefore 
earnings through the residual double taxation of retained earnings. A simple imputation-credit or dividend-deduction system would tax distributed earnings at the personal rate, and retained earnings at the corporate rate. Retained earnings would be subject to a second level of tax-albeit a deferred one-at the time of sale. Even if corporate and personal income were taxed at the same rates, retained earnings might be taxed more heavily than dividends. The element of double taxation, however, can be eliminated by a device, known as a Dividend Reinvestment Plan, or DRIP, which would ensure that retained earnings were taxed only at the corporate level. ${ }^{172}$

Tax reformers can increase managerial support for integration by opposing reforms that would permit selective avoidance of double taxation by some firms. Such reforms will only weaken political pressure to integrate. ${ }^{173}$ The most important device for avoiding double taxation is the use of noncorporate forms such as partnership and Subchapter S. Rebecca Rudnick first observed that double taxation seemed to depend more on whether a firm was publicly held than on whether it was organized as a corporation. ${ }^{174}$ Rudnick concluded that the benefits of access to securities markets formed the normative basis for double taxation. Consequently, she endorsed, at least under present conditions, double taxation of publicly held entities only. While we agree with her observation, we believe that the connection between public ownership and double taxation explains why we have the current tax code rather than why we should retain it. The single-level taxation of closely held

be taxed at statutory corporate rates. Such a plan would in general reduce the lock-in effect. But without preference pass-through, dividend-exclusion systems would tax retained and distributed earnings at different effective rates. Such a dividend-exclusion system received-for rather different reasons-the tentative endorsement of the Treasury integration study. See DEPARTMENT OF THE TREASURY, INTEGRATION, supra note 10 , at $15,17-25$.

172. Under a DRIP, the corporate tax paid on retained earnings is attributed to shareholders by means of a deemed dividend. This deemed dividend would increase shareholder basis, and therefore reduce gain at the time of sale. A DRIP would thus reduce the effect of the tax system on the decision to retain or distribute earnings. Any bias would be caused solely by the difference between corporate and personal rates. Such an imputation credit system has been endorsed - on other grounds-by the ALI integration study and the American Institute of Certified Public Accountants. See TAX DIVISION, AMERICAN INST. OF CERTIFED PUB. ACCOUNTANTS, supra note 17, at 54-59, 63-67. In principle, a DRIP could also supplement a dividend-deduction system. The principal difference between the imputation-credit and dividend-deduction systems is administrative: An imputation-credit system uses corporate-level taxation of dividends as a withholding regime. This difference makes a DRIP more sensible with an imputation-credit system. Since the major advantage of the dividend-deduction system is simplicity, most proposed versions, as well as the partial dividend-deduction system formerly in effect, would not use a DRIP or other basis adjustments. Such adjustments would considerably complicate the system without providing the advantages of withholding.

173. Piecemeal integration is particularly to be avoided if the managers who would oppose integration because they favor retained earnings do not have sufficient political power to block across-the-board integration under a phased-in integration plan that does eliminate the trap. Our conclusion that, in the absence of full integration, the current double-tax system should be seriously enforced is shared by others, although for different reasons. See, e.g., CORPORATE TAX REFORM, supra note 74, at 162 (comments of Professor Michael Graetz, arguing that double taxation will remain because decreed by Congress despite weight of tax policy analysis against it). This view seems to stem primarily from a respect for democratic procedures and the rule of law. Leonard, supra note 65 , at 891,895 .

174. See Rudnick, supra note 15, at 1099-1143. 
businesses reduces one of the few potentially powerful forces for integration. We therefore believe that reformers should consider opposing the gradual extension of Subchapter $S$ and related innovations.

\section{CONCLUSION}

The double taxation of corporate profits creates significant distortions in the American economy. The two-tier tax discourages investment in the corporate sector, encourages dangerous levels of corporate debt, and encourages corporations to retain earnings.

The persistence of the corporate tax, we have argued, results from the separation between the ownership and the management of large corporations. To a limited extent, the tax persists because of the retained earnings trap. In the absence of a corporate tax, shareholders will pressure managers to pay dividends if the return on outside investments is higher than the return inside the corporation. A two-tier tax reduces these pressures by bringing shareholder objectives closer to those of management. Consequently, a small group of managers who benefit from the tax vehemently oppose integration.

Most managers, however, do not oppose integration. For them, the cost of the tax, especially the inducement it provides to debt finance, far outweighs the benefits. Yet even these managers have been unwilling to lobby energetically against the double tax. Integration would produce a substantial revenue loss that would, they fear, be financed by the reduction of capital subsidies such as ACRS. Much of this revenue loss would generate windfall gains to shareholders while providing no benefit to managers. Many managers also prefer tax breaks targeted to their firms to integration.

Integration proponents, we suggest, should consider two strategies to enlist the support of corporate management. As a long-term strategy, reformers should support efforts to remove impediments to shareholder voice. More immediately, reformers should consider proposing versions of integration that are acceptable to the majority of managers who are not opposed to integration as such. To eliminate the concern that integration will be unnecessarily expensive, integration proposals should provide subsidies only to new capital. Reformers should also consider enlisting the aid of managers who want a retained earnings trap by proposing plans that would preserve it. The most politically promising integration scheme would be an imputation-credit method. The ideal version of this method would avoid residual double taxation of retained earnings with a DRIP. To reinforce the gap between shareholder and individual rates, the system should not extend preferences to shareholders. By preserving the earnings trap, this plan would maintain an important inefficiency of the corporate tax but would have a much greater chance of passage than plans that would eliminate it. 
In addition, reformers should oppose proposals that would enable additional firms to avoid the double tax. Firms on which the double-level tax imposes the greatest burden have in the past supported integration efforts. Current tax law makes it unnecessarily easy for the managers of some publicly held corporations to reduce the burden of two levels of tax while using the earnings trap to justify earnings retention. The corporate tax weighs only lightly on those managers who are also principal equity holders. Resisting efforts to loosen the rules that apply to partnerships and closely held corporations, we suggest, might induce this group to exert their considerable influence on behalf of integration proposals.

More generally, we believe that the history of integration efforts holds a lesson for those who seek to reform other aspects of the tax code. Effective reform requires a grasp of the flaws in current law and a plan to remedy those flaws. Reformers, however, must devise not only solutions, but solutions that can realistically be enacted as law. In this effort, they would do well to invest effort in understanding why the problem they seek to solve has persisted. 


\section{APPENDIX A: TESTIMONY AT INTEGRATION HEARINGS ${ }^{175}$}

TABLE A.1. House $1975^{176}$

\begin{tabular}{||l|c|c|c|c|c||}
\hline $\begin{array}{l}\text { COMPANY OR } \\
\text { ORGANIZATION }\end{array}$ & ETR & INTEGRATION & ACRS & $\begin{array}{c}\text { LOW CORP. } \\
\text { RATE }\end{array}$ & ITC \\
\hline $\begin{array}{l}\text { METAL } \\
\text { MANUFACTURING }\end{array}$ & & & & & \\
\hline $\begin{array}{l}\text { American Iron } \\
\text { \& Steel Inst. }\end{array}$ & $18.5 \%$ & Yes & Yes & Yes & Yes \\
\hline $\begin{array}{l}\text { American Iron } \\
\text { Ore Ass'n }\end{array}$ & $18.5 \%$ & No Opinion & Yes & Yes & Yes \\
\hline METAL PRODUCTS & & & & & Yes \\
\hline $\begin{array}{l}\text { George A. } \\
\text { Strichman, } \\
\text { Chairman, } \\
\text { Ad Hoc Comm. } \\
\text { for an Effective } \\
\text { Inv. Tax Credit } \\
\text { (\& Chairman of } \\
\text { the Bd. \& CEO } \\
\text { of a member, } \\
\text { Colt Indus.) }\end{array}$ & $(36.0 \%)$ & No Opinion & Yes & No Opinion & Yes \\
\hline $\begin{array}{l}\text { American } \\
\text { Machine Tool } \\
\text { Distribs. Ass'n }\end{array}$ & $(36.0 \%)$ & No Opinion & Yes & No Opinion & Yes \\
\hline $\begin{array}{l}\text { Associated } \\
\text { Equipment } \\
\text { Distribs. }\end{array}$ & $(36.0 \%)$ & Yes & Yes & No Opinion & Yes \\
\hline $\begin{array}{l}\text { Machinery } \\
\text { Dealers } \\
\text { Nat'1 Ass'n }\end{array}$ & $(36.0 \%)$ & No Opinion & No Opinion & No Opinion & Yes \\
\hline $\begin{array}{l}\text { National Mach. } \\
\text { Tool Builders } \\
\text { Ass'n }\end{array}$ & $(36.0 \%)$ & No Opinion & Yes & No Opinion & Yes \\
\hline
\end{tabular}

175. Effective tax rates (ETR) figures on Tables A.1, A.2, and A.3 are from Sanjay Gupta \& Kaye Newberry, Corporate Average Effective Tax Rates After the Tax Reform Act of 1986, 55 TAX NoTES 689 (1982). Unless otherwise indicated, figures are from id. at 700 (tbl. 2), and are the Joint Committee on Taxation (JCT) estimates for 1980, $i d$. These are the earliest ETR estimates available. Figures in parentheses indicate the JCT average for 1981-83. Because of the tax cuts in the early 1980s, these figures probably significantly underestimate the effective tax rates the companies faced from 1975 to 1977 .

176. Source: Tax Reform: Public Hearings Before the House Comm. on Ways and Means, 94th Cong., 1st Sess. (1975). 


\begin{tabular}{|c|c|c|c|c|c|}
\hline $\begin{array}{l}\text { COMPANY OR } \\
\text { ORGANIZATION }\end{array}$ & ETR & INTEGRATION & ACRS & $\begin{array}{c}\text { LOW CORP. } \\
\text { RATE }\end{array}$ & ITC \\
\hline $\begin{array}{l}\text { National Tool, } \\
\text { Die \& Precision } \\
\text { Mach. Ass'n }\end{array}$ & $(36.0 \%)$ & No Opinion & Yes & No Opinion & Yes \\
\hline $\begin{array}{l}\text { Stephen } \\
\text { Furbacher, } \\
\text { Pres., Neptune } \\
\text { Int'l, on Behalf } \\
\text { of Comm. of } \\
\text { Publicly Owned } \\
\text { Cos. }\end{array}$ & $(36.0 \%)$ & Yes & No Opinion & No Opinion & No Opinion \\
\hline \multicolumn{6}{|l|}{$\begin{array}{l}\text { TRANSPORTATION } \\
\text {-AIR }\end{array}$} \\
\hline $\begin{array}{l}\text { Air Transp. } \\
\text { Ass'n }\end{array}$ & $14.5 \%$ & No Opinion & No Opinion & No Opinion & Yes \\
\hline $\begin{array}{l}\text { Transportation } \\
\text { Ass'n of Am. }\end{array}$ & $14.5 \%$ & No Opinion & No Opinion & No Opinion & Yes \\
\hline \multicolumn{6}{|l|}{$\begin{array}{l}\text { TRANSPORTATION } \\
\text {-RAIL }\end{array}$} \\
\hline $\begin{array}{l}\text { Association of } \\
\text { Am. R.Rs. }\end{array}$ & $10.7 \%$ & No Opinion & . Yes & No Opinion & Yes \\
\hline $\begin{array}{l}\text { Chicago \& } \\
\text { Northwestern } \\
\text { R.R. }\end{array}$ & $10.7 \%$ & No Opinion & No Opinion & No Opinion & Yes \\
\hline \multicolumn{6}{|l|}{$\begin{array}{l}\text { INVESTMENT } \\
\text { COMPANIES }\end{array}$} \\
\hline Merrill Lynch & $(18.6 \%)$ & Yes & Yes & Yes & Yes \\
\hline $\begin{array}{l}\text { National Ass'n } \\
\text { of Inv. Clubs }\end{array}$ & $(18.6 \%)$ & Yes & No Opinion & No Opinion & No Opinion \\
\hline $\begin{array}{l}\text { Stockholders of } \\
\text { Am. }\end{array}$ & $(18.6 \%)$ & Yes & No Opinion & No Opinion & No Opinion \\
\hline $\begin{array}{l}\text { Cantor, } \\
\text { Fitzgerald } \\
\& \text { Co. }\end{array}$ & $(18.6 \%)$ & Yes & No Opinion & No Opinion & No Opinion \\
\hline $\begin{array}{l}\text { National Ass'n } \\
\text { of Small Bus. } \\
\text { Inv. Cos. }\end{array}$ & $(18.6 \%)$ & Yes & No Opinion & No Opinion & Yes \\
\hline $\begin{array}{l}\text { Kelso Bangert } \\
\& \text { Co. }\end{array}$ & $(18.6 \%)$ & Yes & No & No & No \\
\hline
\end{tabular}




\begin{tabular}{|c|c|c|c|c|c|}
\hline $\begin{array}{l}\text { COMPANY OR } \\
\text { ORGANIZATION }\end{array}$ & ETR & INTEGRATION & ACRS & $\begin{array}{c}\text { LOW CORP. } \\
\text { RATE }\end{array}$ & ITC \\
\hline \multicolumn{6}{|l|}{$\begin{array}{l}\text { PAPER AND } \\
\text { WOOD PRODUCTS }\end{array}$} \\
\hline $\begin{array}{l}\text { Forest Indus. } \\
\text { Comm'n }\end{array}$ & $7.0 \%$ & No Opinion & No Opinion & Yes & No Opinion \\
\hline $\begin{array}{l}\text { Edward Knapp, } \\
\text { Forestry } \\
\text { Consultant }\end{array}$ & $7.0 \%$ & No Opinion & No Opinion & Yes & No Opinion \\
\hline Mead & $7.0 \%$ & Yes & Yes & No Opinion & Yes \\
\hline \multicolumn{6}{|l|}{ PETROLEUM } \\
\hline $\begin{array}{l}\text { C.V. Wood, Jr., } \\
\text { Pres., } \\
\text { McCulloch Oil, } \\
\text { on Behalf of } \\
\text { Comm. of } \\
\text { Publicly Owned } \\
\text { Cos. }\end{array}$ & $44.7 \%$ & Yes & No Opinion & No Opinion & No Opinion \\
\hline $\begin{array}{l}\text { Fred A. } \\
\text { Simpson, } \\
\text { Sr., } \\
\text { Vice Pres., } \\
\text { Baker Oil } \\
\text { Tools, } \\
\text { on Behalf of } \\
\text { Comm. of } \\
\text { Publicly Owned } \\
\text { Cos. }\end{array}$ & $44.7 \%$ & Yes & No Opinion & No Opinion & No Opinion \\
\hline \multicolumn{6}{|l|}{ RETAIIING } \\
\hline $\begin{array}{l}\text { National Ass'n } \\
\text { of Chain } \\
\text { Drugstores }\end{array}$ & $35.1 \%$ & Yes & No Opinion & Yes & Yes \\
\hline $\begin{array}{l}\text { National Retail } \\
\text { Merchants } \\
\text { Ass'n }\end{array}$ & $35.1 \%$ & No Opinion & Yes & No Opinion & Yes \\
\hline \multicolumn{6}{|l|}{ CHEMICALS } \\
\hline Allied Chem. & $30.3 \%$ & No Opinion & No Opinion & No Opinion & No Opinion \\
\hline \multicolumn{6}{|l|}{ BROADCASTING } \\
\hline Media General & $(17.7 \%)$ & No Opinion & No Opinion & No Opinion & Yes \\
\hline
\end{tabular}




\begin{tabular}{|c|c|c|c|c|c|}
\hline $\begin{array}{l}\text { COMPANY OR } \\
\text { ORGANIZATION }\end{array}$ & ETR & INTEGRATION & ACRS & $\begin{array}{c}\text { LOW CORP. } \\
\text { RATE }\end{array}$ & ITC \\
\hline \multicolumn{6}{|l|}{$\begin{array}{l}\text { FOOD } \\
\text { PROCESSORS }\end{array}$} \\
\hline $\begin{array}{l}\text { Leonard Marks, } \\
\text { Jr., Exec. Vice } \\
\text { Pres., Castle \& } \\
\text { Cooke, on } \\
\text { Behalf of } \\
\text { Comm. of } \\
\text { Publicly Owned } \\
\text { Cos. }\end{array}$ & $37.6 \%$ & Yes & No Opinion & No Opinion & No Opinion \\
\hline \multicolumn{6}{|l|}{ MOTOR VEHICLES } \\
\hline $\begin{array}{l}\text { Automotive } \\
\text { Serv. } \\
\text { Indus. Ass'n }\end{array}$ & $(10.4 \%)$ & No Opinion & No Opinion & Yes & No Opinion \\
\hline \multicolumn{6}{|l|}{ INSTRUMENTS } \\
\hline $\begin{array}{l}\text { Beckman } \\
\text { Instruments }\end{array}$ & $40.7 \%$ & Yes & No Opinion & No Opinion & No Opinion \\
\hline \multicolumn{6}{|l|}{ BANKING } \\
\hline $\begin{array}{l}\text { Chase } \\
\text { Manhattan }\end{array}$ & N/A & Yes & Yes & Yes & Yes \\
\hline $\begin{array}{l}\text { City Nat'l Bank } \\
\& \text { Trust of } \\
\text { Columbus }\end{array}$ & N/A & Yes & Yes & Yes & Yes \\
\hline $\begin{array}{l}\text { First Nat'l Bank } \\
\text { of Oklahoma } \\
\text { City }\end{array}$ & N/A & Yes & No Opinion & No Opinion & Yes \\
\hline $\begin{array}{l}\text { First Nat'l City } \\
\text { Bank of N.Y. }\end{array}$ & N/A & Yes & Yes & Yes & Yes \\
\hline $\begin{array}{l}\text { Iowa Des } \\
\text { Moines Nat'1 } \\
\text { Bank }\end{array}$ & N/A & Yes & No Opinion & No Opinion & Yes \\
\hline \multicolumn{6}{|l|}{ MISCELLANEOUS } \\
\hline $\begin{array}{l}\text { American } \\
\text { Council } \\
\text { for Capital } \\
\text { Formation }\end{array}$ & N/A & Yes & Yes & Yes & Yes \\
\hline $\begin{array}{l}\text { Public Citizen } \\
\text { Tax Reform } \\
\text { Research Group }\end{array}$ & N/A & No Opinion & No Opinion & No & No \\
\hline $\begin{array}{l}\text { New York } \\
\text { Citizens for } \\
\text { Tax Reform }\end{array}$ & N/A & No Opinion & No & No & No \\
\hline
\end{tabular}




\begin{tabular}{||l|c|c|c|c|c||}
\hline $\begin{array}{l}\text { COMPANY OR } \\
\text { ORGANIZATION }\end{array}$ & ETR & INTEGRATION & ACRS & $\begin{array}{c}\text { LOW CORP. } \\
\text { RATE }\end{array}$ & ITC \\
\hline $\begin{array}{l}\text { Tax Equity for } \\
\text { Am. }\end{array}$ & N/A & No Opinion & No & No Opinion & No \\
\hline $\begin{array}{l}\text { Joseph A. } \\
\begin{array}{l}\text { Pechman, } \\
\text { Brookings } \\
\text { Inst. }\end{array}\end{array}$ & N/A & Yes & No Opinion & No Opinion & No Opinion \\
\hline $\begin{array}{l}\text { Illinois } \\
\text { Chamber } \\
\text { of Commerce }\end{array}$ & N/A & No Opinion & Yes & No Opinion & Yes \\
\hline $\begin{array}{l}\text { New York } \\
\text { Stock } \\
\text { Exch. }\end{array}$ & N/A & Yes & Yes & Yes & Yes \\
\hline
\end{tabular}


TABLE A.2. Senate $1975^{177}$

\begin{tabular}{|c|c|c|c|c|c|}
\hline $\begin{array}{l}\text { COMPANY OR } \\
\text { ORGANIZATION }\end{array}$ & ETR & INTEGRATION & ACRS & $\begin{array}{c}\text { LOW CORP. } \\
\text { RATE }\end{array}$ & ITC \\
\hline \multicolumn{6}{|l|}{$\begin{array}{l}\text { METAL } \\
\text { MANUFACTURING }\end{array}$} \\
\hline $\begin{array}{l}\text { National Ass'n } \\
\text { of Mfrs. }\end{array}$ & $18.5 \%$ & Yes & Yes & Yes & Yes \\
\hline $\begin{array}{l}\text { Machine \& } \\
\text { Allied Products } \\
\text { Inst. }\end{array}$ & $18.5 \%$ & Yes & Yes & Yes & Yes \\
\hline \multicolumn{6}{|l|}{$\begin{array}{l}\text { PAPER \& WOOD } \\
\text { PRODUCTS }\end{array}$} \\
\hline $\begin{array}{l}\text { American Paper } \\
\text { Inst. }\end{array}$ & $7.0 \%$ & Yes & Yes & Yes & Yes \\
\hline \multicolumn{6}{|l|}{ MINING } \\
\hline $\begin{array}{l}\text { American } \\
\text { Mining } \\
\text { Congress Tax } \\
\text { Comm. } \\
\end{array}$ & N/A & Yes & Yes & No Opinion & Yes \\
\hline \multicolumn{6}{|l|}{ RUBBER } \\
\hline $\begin{array}{l}\text { Rubber Mfrs. } \\
\text { Ass'n }\end{array}$ & $(47.3 \%)$ & Yes & Yes & No Opinion & Yes \\
\hline \multicolumn{6}{|l|}{ TEXTILES } \\
\hline $\begin{array}{l}\text { American } \\
\text { Textiles Mfrs. }\end{array}$ & N/A & Yes & Yes & No Opinion & Yes \\
\hline \multicolumn{6}{|l|}{ MISCELLANEOUS } \\
\hline $\begin{array}{l}\text { U.S. Chamber } \\
\text { of Commerce }\end{array}$ & N/A & Yes & Yes & Yes & Yes \\
\hline $\begin{array}{l}\text { American Inst. } \\
\text { of Certified } \\
\text { Pub. } \\
\text { Accountants }\end{array}$ & N/A & Yes & No Opinion & Yes & Yes \\
\hline $\begin{array}{l}\text { Council of State } \\
\text { Chambers of } \\
\text { Commerce }\end{array}$ & N/A & Yes & Yes & Yes & Yes \\
\hline $\begin{array}{l}\text { National } \\
\text { Dividend Plan }\end{array}$ & N/A & Yes & No Opinion & No Opinion & No Opinion \\
\hline
\end{tabular}

177. Source: Tax Reform Act of 1975: Hearings Before the Senate Comm. on Finance, 94th Cong., 2d Sess. (1976). 
TABLE A.3. House $1978^{178}$

\begin{tabular}{|c|c|c|c|c|c|}
\hline $\begin{array}{l}\text { COMPANY OR } \\
\text { ORGANIZATION }\end{array}$ & ETR & INTEGRATION & ACRS & $\begin{array}{c}\text { LOW CORP. } \\
\text { RATE } \\
\end{array}$ & ITC \\
\hline \multicolumn{6}{|l|}{$\begin{array}{l}\text { INVESTMENT } \\
\text { COMPANIES }\end{array}$} \\
\hline $\begin{array}{l}\text { Securities } \\
\text { Indus. Ass'n }\end{array}$ & $(18.6 \%)$ & Yes & No Opinion & No Opinion & No Opinion \\
\hline $\begin{array}{l}\text { Public Sec. } \\
\text { Ass'n }\end{array}$ & $(18.6 \%)$ & Yes & No Opinion & No Opinion & No Opinion \\
\hline \multicolumn{6}{|l|}{ RETAILING } \\
\hline $\begin{array}{l}\text { Sears Roebuck } \\
\& \text { Co. }\end{array}$ & $35.1 \%$ & Yes & No Opinion & No Opinion & Yes \\
\hline \multicolumn{6}{|l|}{$\begin{array}{l}\text { TELECOMMUN- } \\
\text { ICATIONS }\end{array}$} \\
\hline AT\&T & $(4.0 \%)$ & Yes & No Opinion & No Opinion & No Opinion \\
\hline \multicolumn{6}{|l|}{ BANKING } \\
\hline $\begin{array}{l}\text { American } \\
\text { Bankers Ass'n }\end{array}$ & N/A & Yes & Yes & Yes & Yes \\
\hline \multicolumn{6}{|l|}{ MisCELLANEOUS } \\
\hline $\begin{array}{l}\text { Arthur } \\
\text { Andersen \& Co. }\end{array}$ & N/A & Yes & No Opinion & No Opinion & No Opinion \\
\hline $\begin{array}{l}\text { National Ass'n } \\
\text { of Mfrs. }\end{array}$ & N/A & Yes & No Opinion & No Opinion & No Opinion \\
\hline $\begin{array}{l}\text { Martin } \\
\text { Feldstein, } \\
\text { National Bureau } \\
\text { of Economic } \\
\text { Research and } \\
\text { Harvard Univ. }\end{array}$ & N/A & Yes & No Opinion & Yes & Yes \\
\hline $\begin{array}{l}\text { Sheldon S. } \\
\text { Cohen, Cohen } \\
\text { \& Uretz }\end{array}$ & N/A & No & No Opinion & No Opinion & No Opinion \\
\hline $\begin{array}{l}\text { Frederic W. } \\
\text { Hickman, } \\
\text { Hopkins, Sutter, } \\
\text { Mulroy, Davis } \\
\text { \& Cromarite } \\
\end{array}$ & N/A & Yes & Yes & No Opinion & Yes \\
\hline $\begin{array}{l}\text { Commonwealth } \\
\text { Edison }\end{array}$ & N/A & Yes & Yes & No Opinion & Yes \\
\hline
\end{tabular}




\begin{tabular}{||l|c|c|c|c|c||}
\hline $\begin{array}{l}\text { COMPANY OR } \\
\text { ORGANIZATION }\end{array}$ & ETR & INTEGRATION & ACRS & $\begin{array}{c}\text { LOW CORP. } \\
\text { RATE }\end{array}$ & ITC \\
\hline $\begin{array}{l}\text { New York State } \\
\text { Bar Ass'n }\end{array}$ & N/A & Yes & No Opinion & No Opinion & No Opinion \\
\hline $\begin{array}{l}\text { Ernest S. } \\
\text { Christian, Jr., } \\
\begin{array}{l}\text { Patton, Boggs } \\
\& \text { Blow }\end{array}\end{array}$ & N/A & Yes & No Opinion & No Opinion & No Opinion \\
\hline $\begin{array}{l}\text { Municipal Fin. } \\
\text { Officers Ass'n }\end{array}$ & N/A & No Opinion & No Opinion & No Opinion & No Opinion \\
\hline TIAA-CREF & N/A & Yes & No Opinion & No Opinion & No Opinion \\
\hline
\end{tabular}




\section{APPENDIX B: PUBLIC OPINION POLLS}

TABLE B.1. Views on Corporate Tax ${ }^{179}$

\begin{tabular}{|c|c|c|}
\hline QUESTION & RESPONSES & $\begin{array}{c}\text { POLLING ORGANIZATION, } \\
\text { SOURCE, AND RELEASE } \\
\text { DATE }\end{array}$ \\
\hline $\begin{array}{l}\text { "I would like to read some } \\
\text { elements of President (Bill) } \\
\text { Clinton's economic plan. Do } \\
\text { you favor or oppose . . . } \\
\text { increasing the corporate tax } \\
\text { rate from thirty-four percent to } \\
\text { thirty-six percent?" }\end{array}$ & $\begin{array}{l}\text { Favor } 65 \% \\
\text { Oppose } 29 \% \\
\text { Not sure } 6 \%\end{array}$ & $\begin{array}{l}\text { Hart and Teeter Research } \\
\text { Companies (NBCWSJ) } \\
\text { NBC News/Wall Street } \\
\text { Journal } \\
03 / 11 / 93\end{array}$ \\
\hline $\begin{array}{l}\text { "I am going to read some } \\
\text { economic proposals being } \\
\text { considered by the (President } \\
\text { Bill) Clinton administration. } \\
\text { For each one, please tell me } \\
\text { whether you would favor or } \\
\text { oppose it being included in } \\
\text { Clinton's economic plan. . . } \\
\text { Increasing the tax rate on } \\
\text { businesses and corporations." }\end{array}$ & $\begin{array}{l}\text { Favor } 62 \% \\
\text { Oppose } 32 \% \\
\text { Don't know/Refused to } \\
\text { respond } 6 \%\end{array}$ & $\begin{array}{l}\text { Gallup Organization } \\
\text { (Gallup) } \\
\text { Gallup/C.N.N./U.S.A. } \\
\text { Today } \\
02 / 00 / 93\end{array}$ \\
\hline
\end{tabular}

179. Source: Searches conducted in DIALOG, Poll database. The dates in this table appear in Westlaw format to facilitate reproduction of our searches. For example, " 00 " indicates that a poll took place over the course of a given month. 


\begin{tabular}{|c|c|c|}
\hline QUESTION & RESPONSES & $\begin{array}{c}\text { POLIING ORGANIZATION, } \\
\text { SOURCE, AND RELEASE } \\
\text { DATE }\end{array}$ \\
\hline $\begin{array}{l}\text { "I'm going to mention some } \\
\text { specific things President (Bill) } \\
\text { Clinton proposed in his } \\
\text { economic address (to Congress } \\
\text { February } 17,1993 \text { ) as part of } \\
\text { his program to improve the } \\
\text { nation's economy and reduce } \\
\text { the federal budget deficit. For } \\
\text { each, would you please tell me } \\
\text { if you favor or oppose this } \\
\text { particular part of his proposal. } \\
\text {. . In order to help reduce the } \\
\text { federal budget deficit, Clinton } \\
\text { proposed raising the tax rate on } \\
\text { corporate profits over } \$ 10 \\
\text { million dollars, from } 34 \text { to } 36 \\
\text { percent. Do you favor or } \\
\text { oppose this part of Clinton's } \\
\text { economic program? (If favor or } \\
\text { oppose) Is that (favor/oppose) } \\
\text { strongly or (favor/oppose) } \\
\text { somewhat?" }\end{array}$ & $\begin{array}{l}\text { Favor strongly } 51 \% \\
\text { Favor somewhat } 26 \% \\
\text { Oppose somewhat } 9 \% \\
\text { Oppose strongly } 9 \% \\
\text { Not sure } 5 \%\end{array}$ & $\begin{array}{l}\text { Los Angeles Times (LAT) } \\
\text { Los Angeles Times } \\
02 / 00 / 93\end{array}$ \\
\hline $\begin{array}{l}\text { "Do you favor or oppose the } \\
\text { following proposals to reduce } \\
\text { the federal budget deficit? } \\
\text { Increasing taxes on } \\
\text { corporations." }\end{array}$ & $\begin{array}{l}\text { Favor } 69 \% \\
\text { Oppose } 22 \% \\
\text { Not sure } 9 \%\end{array}$ & $\begin{array}{l}\text { Yankelovich Clancy } \\
\text { Shulman (YANKCS) } \\
\text { Time/Yankelovich Clancy } \\
\text { Shulman } \\
02 / 18 / 88 \\
\end{array}$ \\
\hline $\begin{array}{l}\text { "I am going to mention some } \\
\text { things that have been proposed } \\
\text { to help balance the federal } \\
\text { budget, and for each please tell } \\
\text { me whether you approve or } \\
\text { disapprove of that } \\
\text { proposal. . . . Do you approve } \\
\text { or disapprove ... raising taxes } \\
\text { on business corporations ... to } \\
\text { help balance the federal } \\
\text { budget?" }\end{array}$ & $\begin{array}{l}\text { Approve } 67 \% \\
\text { Disapprove } 32 \% \\
\text { Don't know/No opinion } 1 \%\end{array}$ & $\begin{array}{l}\text { ABC News/Washington } \\
\text { Post (ABCWP) } \\
\text { ABC News/Washington } \\
\text { Post } \\
06 / 29 / 87\end{array}$ \\
\hline
\end{tabular}




\begin{tabular}{|c|c|c|}
\hline QUESTION & RESPONSES & $\begin{array}{c}\text { POLLING ORGANIZATION, } \\
\text { SOURCE, AND RELEASE } \\
\text { DATE }\end{array}$ \\
\hline $\begin{array}{l}\text { "As you know, the national } \\
\text { deficit is estimated to reach } \\
\text { approximately } \$ 175 \text { billion in } \\
1985 \text {. Here are some steps } \\
\text { people have suggested could be } \\
\text { taken to reduce the deficit. For } \\
\text { each one, would you tell me } \\
\text { whether you think it is a step } \\
\text { that should or should not be } \\
\text { very seriously considered as a } \\
\text { way of reducing the } \\
\text { deficit? ... An increase in } \\
\text { corporate income taxes." }\end{array}$ & $\begin{array}{l}\text { Should be seriously } \\
\text { considered } 73 \% \\
\text { Should not be seriously } \\
\text { considered } 21 \% \\
\text { Don't know } 5 \% \\
\end{array}$ & $\begin{array}{l}\text { Roper Organization (Roper) } \\
\text { Roper Report 85-1 } \\
02 / 08 / 85\end{array}$ \\
\hline $\begin{array}{l}\text { "In order to reduce the federal } \\
\text { deficit, would you favor or } \\
\text { oppose ... substantial } \\
\text { increases in federal taxes on } \\
\text { corporations?" }\end{array}$ & $\begin{array}{l}\text { Favor } 62 \% \\
\text { Oppose } 31 \% \\
\text { Not sure } 6 \%\end{array}$ & $\begin{array}{l}\text { Louis Harris \& Associates } \\
\text { (HARRBW) } \\
\text { Business Week/Harris } \\
01 / 30 / 84\end{array}$ \\
\hline $\begin{array}{l}\text { "There have been many } \\
\text { suggestions made for } \\
\text { decreasing the federal budget } \\
\text { deficit, either by raising taxes } \\
\text { or by cutting expenses. As I } \\
\text { read each of these suggestions, } \\
\text { please tell me, for each, } \\
\text { whether you strongly favor, } \\
\text { somewhat favor, somewhat } \\
\text { oppose, or strongly oppose } \\
\text { it. . . Raise the federal income } \\
\text { tax on corporations." }\end{array}$ & $\begin{array}{l}\text { Strongly oppose } 12 \% \\
\text { Somewhat oppose } 16 \% \\
\text { Somewhat favor } 25 \% \\
\text { Strongly favor } 42 \% \\
\text { No opinion } 5 \%\end{array}$ & $\begin{array}{l}\text { Opinion Research } \\
\text { Corporation (ORC) } \\
\text { Public Opinion Index } \\
05 / 00 / 84\end{array}$ \\
\hline $\begin{array}{l}\text { "In order to reduce the size of } \\
\text { the federal deficit, are you } \\
\text { willing or not willing to see the } \\
\text { government raise taxes on } \\
\text { business and corporations or } \\
\text { aren't you sure?" }\end{array}$ & $\begin{array}{l}\text { Willing } 63 \% \\
\text { Not willing } 31 \% \\
\text { Not sure } 6 \%\end{array}$ & $\begin{array}{l}\text { Yankelovich, Skelly and } \\
\text { White (YANK) } \\
\text { Time/Yankelovich, Skelly } \\
\text { and White } \\
02 / 02 / 84\end{array}$ \\
\hline
\end{tabular}




\begin{tabular}{|c|c|c|}
\hline QUESTION & RESPONSES & $\begin{array}{c}\text { POLIING ORGANIZATION, } \\
\text { SOURCE, AND RELEASE } \\
\text { DATE }\end{array}$ \\
\hline $\begin{array}{l}\text { "In order to achieve a balanced } \\
\text { budget are you willing or not } \\
\text { willing to see the government } \\
\text { raise taxes on business and } \\
\text { corporations or aren't you } \\
\text { sure?" }\end{array}$ & $\begin{array}{l}\text { Willing } 59 \% \\
\text { Not willing } 34 \% \\
\text { Not sure } 7 \%\end{array}$ & $\begin{array}{l}\text { Yankelovich, Skelly and } \\
\text { White (YANK) } \\
\text { Time/Yankelovich, Skelly } \\
\text { and White } \\
12 / 00 / 81\end{array}$ \\
\hline $\begin{array}{l}\text { "Let us suppose the } \\
\text { government needed to raise } \\
\text { taxes. For each of the } \\
\text { following, please tell me if you } \\
\text { would favor or oppose raising } \\
\text { that tax. . . Increasing the tax } \\
\text { rate on corporations." }\end{array}$ & $\begin{array}{l}\text { Favor } 70 \% \\
\text { Oppose } 24 \% \\
\text { Not sure } 6 \%\end{array}$ & $\begin{array}{l}\text { Hart and Teeter Research } \\
\text { Companies (NBCWSJ) } \\
\text { NBC News/Wall Street } \\
\text { Journal } \\
07 / 00 / 90 \\
\end{array}$ \\
\hline $\begin{array}{l}\text { "(Various specific tax } \\
\text { proposals have been made to } \\
\text { reduce the federal deficit.) To } \\
\text { cut the size of the budget } \\
\text { deficit, would you favor or } \\
\text { oppose . . . putting an income } \\
\text { tax surcharge of up to } 10 \% \\
\text { more of current taxes on } \\
\text { corporations?" }\end{array}$ & $\begin{array}{l}\text { Favor } 61 \% \\
\text { Oppose } 33 \% \\
\text { Not sure } 6 \%\end{array}$ & $\begin{array}{l}\text { Louis Harris \& Associates } \\
\text { (HARRBW) } \\
\text { Business Week/Harris } \\
01 / 30 / 84\end{array}$ \\
\hline $\begin{array}{l}\text { "President Carter has } \\
\text { recommended a series of tax } \\
\text { changes to the Congress. Let } \\
\text { me read you some of the things } \\
\text { he is recommending. For each, } \\
\text { tell me if you favor or oppose } \\
\text { that tax proposal. . . . Reduce } \\
\text { the general corporate income } \\
\text { tax rate from } 48 \text { percent to } 44 \\
\text { percent by } 1980 . "\end{array}$ & $\begin{array}{l}\text { Favor } 38 \% \\
\text { Oppose } 25 \% \\
\text { Not sure } 37 \% \\
\\
\end{array}$ & $\begin{array}{l}\text { Louis Harris \& Associates } \\
\text { (HARRIS) } \\
\text { Harris Survey } \\
03 / 23 / 78\end{array}$ \\
\hline $\begin{array}{l}\text { "(Now let me ask you about } \\
\text { some specific provisions of the } \\
\text { new Reagan proposal for tax } \\
\text { simplification. For each, tell } \\
\text { me if you would favor or } \\
\text { oppose that provision.) ... A } \\
\text { gradual reduction of the } \\
\text { maximum corporate income tax } \\
\text { to } 33 \% \text {." }\end{array}$ & $\begin{array}{l}\text { Favor } 44 \% \\
\text { Oppose } 46 \% \\
\text { Not sure } 10 \%\end{array}$ & $\begin{array}{l}\text { Louis Harris \& Associates } \\
\text { (HARRBW) } \\
\text { Business Week/Harris Poll } \\
06 / 17 / 85\end{array}$ \\
\hline
\end{tabular}




\begin{tabular}{|c|c|c|}
\hline QUESTION & RESPONSES & $\begin{array}{c}\text { POLLING ORGANIZATION, } \\
\text { SOURCE, AND RELEASE } \\
\text { DATE }\end{array}$ \\
\hline $\begin{array}{l}\text { "Now let me ask you about } \\
\text { some specific provisions of the } \\
\text { tax reform bill that is likely to } \\
\text { be voted on by the House of } \\
\text { Representatives. For each } \\
\text { provision, tell me if you favor } \\
\text { or oppose it? . . . A gradual } \\
\text { reduction of the maximum } \\
\text { corporate income tax from } 46 \\
\text { percent to } 35 \text { percent" }\end{array}$ & $\begin{array}{l}\text { Favor } 42 \% \\
\text { Oppose } 47 \% \\
\text { Not sure } 11 \%\end{array}$ & $\begin{array}{l}\text { Louis Harris \& Associates } \\
\text { (HARRIS) } \\
\text { Harris Survey } \\
11 / 25 / 85\end{array}$ \\
\hline $\begin{array}{l}\text { "From your personal } \\
\text { standpoint, which of these } \\
\text { taxes do you feel are too high, } \\
\text { which too low, and which } \\
\text { about right? . . Federal } \\
\text { corporate taxes." }\end{array}$ & $\begin{array}{l}\text { Too high } 21 \% \\
\text { Too low } 18 \% \\
\text { About right } 14 \% \\
\text { Not sure } 47 \%\end{array}$ & $\begin{array}{l}\text { Louis Harris \& Associates } \\
\text { (HARRIS) } \\
\text { Harris Survey } \\
04 / 12 / 73 \\
\end{array}$ \\
\hline $\begin{array}{l}\text { "From your personal } \\
\text { standpoint, please tell me, for } \\
\text { each tax that I read off to you, } \\
\text { if you feel it is too high, too } \\
\text { low, or about right. . . . Federal } \\
\text { corporate tax." }\end{array}$ & $\begin{array}{l}\text { Too high } 24 \% \\
\text { Too low } 17 \% \\
\text { About right } 12 \% \\
\text { Not sure } 47 \%\end{array}$ & $\begin{array}{l}\text { Louis Harris \& Associates } \\
\text { (HARRIS) } \\
\text { Harris Survey } \\
04 / 14 / 77\end{array}$ \\
\hline $\begin{array}{l}\text { "From your personal } \\
\text { standpoint, please tell me, for } \\
\text { each tax that I read off to you, } \\
\text { if you feel it is too high, too } \\
\text { low, or about right. . . . Federal } \\
\text { corporate tax." }\end{array}$ & $\begin{array}{l}\text { Too high } 27 \% \\
\text { Too low } 12 \% \\
\text { About right } 17 \% \\
\text { Not sure } 44 \%\end{array}$ & $\begin{array}{l}\text { ABC News/Louis Harris \& } \\
\text { Associates } \\
\text { (ABCHS) } \\
\text { Proposition } 13 \\
06 / 19 / 78\end{array}$ \\
\hline $\begin{array}{l}\text { "In order to spur economic } \\
\text { growth, do you think the } \\
\text { federal government should ... } \\
\text { reduce the income tax that } \\
\text { corporations pay . . . or not?" }\end{array}$ & $\begin{array}{l}\text { Should } 24 \% \\
\text { Should not } 73 \% \\
\text { Not sure } 3 \%\end{array}$ & $\begin{array}{l}\begin{array}{l}\text { Louis Harris \& Associates } \\
\text { (HARRBW) }\end{array} \\
\text { Business Week/Harris Poll } \\
\text { 12/02/91 }\end{array}$ \\
\hline
\end{tabular}




\begin{tabular}{|c|c|c|}
\hline QUESTION & RESPONSES & $\begin{array}{c}\text { POLLING ORGANIZATION, } \\
\text { SOURCE, AND RELEASE } \\
\text { DATE }\end{array}$ \\
\hline $\begin{array}{l}\text { "Frequently on any } \\
\text { controversial issue there is no } \\
\text { clear cut side that people take, } \\
\text { and also frequently solutions } \\
\text { on controversial issues are } \\
\text { worked out by compromise. } \\
\text { But I'm going to name some } \\
\text { different things, and for each } \\
\text { one would you tell me whether } \\
\text { on balance you would be more } \\
\text { in favor of it, or more opposed } \\
\text { to it? ... More tax breaks for } \\
\text { corporations so business can } \\
\text { expand." }\end{array}$ & $\begin{array}{l}\text { Favor } 31 \% \\
\text { Opposed to } 48 \% \\
\text { Have mixed feelings/ } \\
\text { Don't know } 21 \%\end{array}$ & $\begin{array}{l}\text { Roper Organization } \\
\text { (ROPER) } \\
\text { Roper Report 78-2 } \\
03 / 00 / 78\end{array}$ \\
\hline $\begin{array}{l}\text { "Many suggestions have been } \\
\text { made for ways to keep the } \\
\text { country growing fast enough } \\
\text { economically. As I read some } \\
\text { of them, please tell me whether } \\
\text { you strongly favor, mildly } \\
\text { favor, mildly oppose, or } \\
\text { strongly oppose each idea.... } \\
\text { Reduce corporate income taxes } \\
\text { so that business will have } \\
\text { money to expand and provide } \\
\text { jobs." }\end{array}$ & $\begin{array}{l}\text { Strongly favor } 33 \% \\
\text { Mildly favor } 33 \% \\
\text { Mildly oppose } 16 \% \\
\text { Strongly oppose } 14 \% \\
\text { No opinion } 4 \%\end{array}$ & $\begin{array}{l}\text { Opinion Research } \\
\text { Corporation (ORC) } \\
\text { Public Opinion Index } \\
\text { 09/30/79 }\end{array}$ \\
\hline $\begin{array}{l}\text { "Many suggestions have been } \\
\text { made for ways to keep the } \\
\text { country growing fast enough } \\
\text { economically. As I read some } \\
\text { of them, please tell me whether } \\
\text { you strongly favor, mildly } \\
\text { favor, mildly oppose, or } \\
\text { strongly oppose each idea.... } \\
\text { Reduce corporate income taxes } \\
\text { so that business will have } \\
\text { money to expand and provide } \\
\text { jobs." }\end{array}$ & $\begin{array}{l}\text { Strongly oppose cuts } 18 \% \\
\text { Mildly oppose } 13 \% \\
\text { Mildly favor } 28 \% \\
\text { Strongly favor } 34 \% \\
\text { No opinion } 7 \%\end{array}$ & $\begin{array}{l}\text { Opinion Research } \\
\text { Corporation (ORC) } \\
\text { Public Opinion Index } \\
07 / 31 / 78\end{array}$ \\
\hline
\end{tabular}




\begin{tabular}{|c|c|c|}
\hline QUESTION & RESPONSES & $\begin{array}{c}\text { POLLING ORGANIZATION, } \\
\text { SOURCE, AND RELEASE } \\
\text { DATE }\end{array}$ \\
\hline $\begin{array}{l}\text { "(Here are some possible ways } \\
\text { for the government to raise } \\
\text { money to reduce the federal } \\
\text { budget deficit. For each, please } \\
\text { tell me whether you support or } \\
\text { oppose it.) . . . higher corporate } \\
\text { taxes. (If 'Support,' ask:) } \\
\text { Would you support higher } \\
\text { corporate taxes even if } \\
\text { businesses passed on the } \\
\text { expense to consumers by } \\
\text { raising the prices for their } \\
\text { goods?" }\end{array}$ & $\begin{array}{l}\text { Support even if businesses } \\
\text { passed on the expense to } \\
\text { consumers } 40 \% \\
\text { Support, but not if } \\
\text { businesses passed on the } \\
\text { expense } 23 \% \\
\text { Support, but don't know if } \\
\text { would still support if } \\
\text { businesses passed on the } \\
\text { expense } 3 \% \\
\text { Oppose } 27 \% \\
\text { Don't Know/No Answer if } \\
\text { support or oppose } 7 \%\end{array}$ & $\begin{array}{l}\text { Associated Press/Media } \\
\text { General (APM/GEN) } \\
\text { Associated Press/Media } \\
\text { General } \\
11 / 00 / 88\end{array}$ \\
\hline
\end{tabular}


TABLE B.2. Views on Dividend Taxation ${ }^{180}$

\begin{tabular}{|c|c|c|}
\hline QUESTIONS & RESPONSES & $\begin{array}{l}\text { POLLING ORGANIZATIONS } \\
\text { AND RELEASE DATE }\end{array}$ \\
\hline $\begin{array}{l}\text { "Many suggestions have been } \\
\text { made for ways to keep the } \\
\text { country growing fast enough } \\
\text { economically. As I read some } \\
\text { of them, please tell me whether } \\
\text { you strongly favor, mildly } \\
\text { favor, mildly oppose, or } \\
\text { strongly oppose it. . . } \\
\text { Encourage individual } \\
\text { investment by eliminating the } \\
\text { tax that stockholders have to } \\
\text { pay on the dividends they } \\
\text { receive from companies." }\end{array}$ & $\begin{array}{l}\text { Strongly oppose } 20 \% \\
\text { Somewhat oppose } 26 \% \\
\text { Somewhat favor } 26 \% \\
\text { Strongly favor } 20 \% \\
\text { No opinion } 8 \% \\
\end{array}$ & $\begin{array}{l}\text { Public Opinion Research } \\
\text { Corporation (ORC) } \\
\text { Public Opinion Index } \\
05 / 00 / 84\end{array}$ \\
\hline $\begin{array}{l}\text { "Many suggestions have been } \\
\text { made for ways to keep the } \\
\text { country growing fast enough } \\
\text { economically. As I read some } \\
\text { of them, please tell me whether } \\
\text { you strongly favor, mildly } \\
\text { favor, mildly oppose, or } \\
\text { strongly oppose each idea. ... } \\
\text { Reduce corporate income taxes } \\
\text { so that business will have more } \\
\text { money to expand and provide } \\
\text { jobs." }\end{array}$ & $\begin{array}{l}\text { Strongly favor } 26 \% \\
\text { Mildly favor } 28 \% \\
\text { Mildly oppose } 21 \% \\
\text { Strongly oppose } 15 \% \\
\text { No opinion } 10 \%\end{array}$ & $\begin{array}{l}\text { Opinion Research } \\
\text { Corporation (ORC) } \\
\text { Public Opinion Index } \\
\text { 09/30/79 }\end{array}$ \\
\hline $\begin{array}{l}\text { "Many suggestions have been } \\
\text { made for ways to keep the } \\
\text { country growing fast enough } \\
\text { economically. As I read some } \\
\text { of them, please tell me whether } \\
\text { you strongly favor, mildly } \\
\text { favor, mildly oppose, or } \\
\text { strongly oppose each idea. ... } \\
\text { Reduce corporate income taxes } \\
\text { so that business will have more } \\
\text { money to expand and provide } \\
\text { jobs." }\end{array}$ & $\begin{array}{l}\text { Strongly oppose } 12 \% \\
\text { Mildly oppose } 20 \% \\
\text { Mildly favor } 28 \% \\
\text { Strongly favor } 24 \% \\
\text { No opinion } 16 \%\end{array}$ & $\begin{array}{l}\text { Opinion Research } \\
\text { Corporation (ORC) } \\
\text { Public Opinion Index } \\
07 / 31 / 78\end{array}$ \\
\hline
\end{tabular}

180. Source: Searches conducted in DIALOG, Poll database. The dates in this table appear in Westlaw format to facilitate reproduction of our searches. For example, " 00 " indicates that a poll took place over the course of a given month. 


\begin{tabular}{|c|c|c|}
\hline QUESTIONS & RESPONSES & $\begin{array}{l}\text { Polling ORGanizations } \\
\text { AND RELEASE DaTE }\end{array}$ \\
\hline $\begin{array}{l}\text { "The elimination of several } \\
\text { deductions has been proposed } \\
\text { in order to reduce the Federal } \\
\text { Income Tax Rates. As I read } \\
\text { the following list, tell me if } \\
\text { you think it will make the tax } \\
\text { system more fair or less fair. } \\
\text { First, elimination of deductions } \\
\text { for: . . the } \$ 100 \text {-per-person } \\
\text { exemption on dividend } \\
\text { income." }\end{array}$ & $\begin{array}{l}\text { More fair } 46 \% \\
\text { Neither } 5 \% \\
\text { Less fair } 34 \% \\
\text { Don't know/refused } 15 \%\end{array}$ & $\begin{array}{l}\text { Gordon S. Black } \\
\text { Corporation (GBUSA) } \\
\text { Gordon S. Black/U.S.A. } \\
\text { Today } \\
\text { 06/00/85 }\end{array}$ \\
\hline $\begin{array}{l}\text { "Economic prosperity for all } \\
\text { requires substantial and } \\
\text { continuing investments in new } \\
\text { plants and equipment. For } \\
\text { example, it takes about } \$ 35,000 \\
\text { in investment to provide a job } \\
\text { for one new worker-the truck } \\
\text { he drives, the factory he works } \\
\text { in, the machines he operates, } \\
\text { and so forth. A number of } \\
\text { economists have expressed } \\
\text { concern about a shortage of } \\
\text { investment capital and where } \\
\text { the new money needed will } \\
\text { come from. Here are five ways } \\
\text { the amount of capital available } \\
\text { for investment in new plants } \\
\text { and equipment could be } \\
\text { increased. I'd like your reaction } \\
\text { to each of these ideas. ... } \\
\text { Reduce taxes on dividends so } \\
\text { that more people will buy } \\
\text { stock. . . Do you think that's } \\
\text { a good idea or is not a good } \\
\text { idea? } \\
\text { "Should we reduce or eliminate } \\
\text { the taxes people pay on the } \\
\text { dividends so that more people } \\
\text { will buy stocks and companies } \\
\text { will have more money to invest } \\
\text { in new plants and equipment?" }\end{array}$ & $\begin{array}{l}\text { Good idea } 62 \% \\
\text { Not a good idea } 22 \% \\
\text { Don't know } 16 \%\end{array}$ & $\begin{array}{l}\text { Roper Organization } \\
\text { (ROPER) } \\
\text { Roper Report } \\
08 / 00 / 87\end{array}$ \\
\hline
\end{tabular}




\begin{tabular}{|c|c|c|}
\hline QUESTIONS & RESPONSES & $\begin{array}{c}\text { POLLING ORGaNIZATIONS } \\
\text { AND RELEASE DATE }\end{array}$ \\
\hline $\begin{array}{l}\text { "Economic prosperity for all } \\
\text { requires substantial and } \\
\text { continuing investments in new } \\
\text { plants and equipment. For } \\
\text { example, it takes about } \$ 35,000 \\
\text { in investment to provide a job } \\
\text { for one new worker-the truck } \\
\text { he drives, the factory he works } \\
\text { in, the machines he operates, } \\
\text { and so forth. A number of } \\
\text { economists have expressed } \\
\text { concern about a shortage of } \\
\text { investment capital and where } \\
\text { the new money needed will } \\
\text { come from. Here are five ways } \\
\text { the amount of capital available } \\
\text { for investment in new plants } \\
\text { and equipment could be } \\
\text { increased. I'd like your reaction } \\
\text { to each of these ideas. (Card } \\
\text { shown respondent.) First, } \\
\text { reduce taxes on dividends so } \\
\text { that more people will buy } \\
\text { stock. Do you think that's a } \\
\text { good idea or is not a good } \\
\text { idea?" }\end{array}$ & $\begin{array}{l}\text { Good idea } 60 \% \\
\text { Not a good idea } 26 \% \\
\text { Don't know } 14 \%\end{array}$ & $\begin{array}{l}\text { Roper Organization } \\
\text { (ROPER) } \\
\text { Roper Report } \\
07 / 00 / 82\end{array}$ \\
\hline
\end{tabular}




\begin{tabular}{|c|c|c|}
\hline QUESTIONS & RESPONSES & $\begin{array}{c}\text { POLLING ORGaNIZATIONS } \\
\text { AND RELEASE DATE }\end{array}$ \\
\hline $\begin{array}{l}\text { "Economic prosperity for all } \\
\text { requires substantial and } \\
\text { continuing investments in new } \\
\text { plants and equipment. For } \\
\text { example, it takes about } \$ 25,000 \\
\text { in investment to provide a job } \\
\text { for one new worker-the truck } \\
\text { he drives, the factory he works } \\
\text { in, the machines he operates, } \\
\text { and so forth. A number of } \\
\text { economists have expressed } \\
\text { concern about a shortage of } \\
\text { investment capital and where } \\
\text { the new money needed will } \\
\text { come from. Here are five ways } \\
\text { the amount of capital available } \\
\text { for investment in new plants } \\
\text { and equipment could be } \\
\text { increased. I'd like your reaction } \\
\text { to each of these ideas. ... } \\
\text { Reduce or eliminate the taxes } \\
\text { people have to pay on the } \\
\text { dividends they receive from } \\
\text { shares of stocks so that more } \\
\text { people will buy stocks and } \\
\text { companies will have more } \\
\text { money to invest in new plants } \\
\text { and equipment from the sale of } \\
\text { their stock. . . Do you think } \\
\text { that's a good idea or is not a } \\
\text { good idea?" }\end{array}$ & $\begin{array}{l}\text { Good idea } 58 \% \\
\text { Not a good idea } 26 \% \\
\text { Don't know } 16 \%\end{array}$ & $\begin{array}{l}\text { Roper Organization } \\
\text { (ROPER) } \\
\text { Roper Report } \\
07 / 00 / 80\end{array}$ \\
\hline
\end{tabular}




\begin{tabular}{|c|c|c|}
\hline QUESTIONS & RESPONSES & $\begin{array}{c}\text { POLLING ORGANIZATIONS } \\
\text { AND RELEASE DATE }\end{array}$ \\
\hline $\begin{array}{l}\text { "Economic prosperity for all } \\
\text { requires substantial and } \\
\text { continuing investments in new } \\
\text { plants and equipment. For } \\
\text { example, it takes about } \$ 25,000 \\
\text { in investment to provide a job } \\
\text { for one new worker-the truck } \\
\text { he drives, the factory he works } \\
\text { in, the machines he operates, } \\
\text { and so forth. A number of } \\
\text { economists have expressed } \\
\text { concern about a shortage of } \\
\text { investment capital and where } \\
\text { the new money needed will } \\
\text { come from. Here are five ways } \\
\text { the amount of capital available } \\
\text { for investment in new plants } \\
\text { and equipment could be } \\
\text { increased. I'd like your reaction } \\
\text { to each of these ideas. . . } \\
\text { Reduce or eliminate the taxes } \\
\text { people have to pay on the } \\
\text { dividends they receive from } \\
\text { shares of stocks so that more } \\
\text { people will buy stocks and } \\
\text { companies will have more } \\
\text { money to invest in new plants } \\
\text { and equipment from the sale of } \\
\text { their stock." }\end{array}$ & $\begin{array}{l}\text { Good idea 53\% } \\
\text { Not a good idea } 26 \% \\
\text { Don't know } 20 \%\end{array}$ & $\begin{array}{l}\text { Roper Organization } \\
\text { (ROPER) } \\
\text { Roper Report 77-6 } \\
06 / 00 / 77\end{array}$ \\
\hline $\begin{array}{l}\text { "(Now let me ask you about } \\
\text { some specific provisions of the } \\
\text { new Reagan proposal for tax } \\
\text { simplification. For each, tell me } \\
\text { if you would favor or oppose } \\
\text { that provision.) .. . Allow } \\
\text { corporations to deduct } 10 \% \text { of } \\
\text { dividend payments to } \\
\text { shareholders. } \\
\text { "Reagan administration } \\
\text { proposal to allow corporations } \\
\text { to deduct } 10 \% \text { of dividend } \\
\text { payments to shareholders?" }\end{array}$ & $\begin{array}{l}\text { Favor } 41 \% \\
\text { Oppose } 50 \% \\
\text { Not sure } 9 \%\end{array}$ & $\begin{array}{l}\text { Louis Harris \& Associates } \\
\text { (HARRBW) } \\
\text { Business Week/Harris Poll } \\
06 / 17 / 85\end{array}$ \\
\hline
\end{tabular}


TABLE B.3. Views on Double Taxation ${ }^{181}$

\begin{tabular}{|c|c|c|}
\hline QUESTIONS & RESPONSES & $\begin{array}{c}\text { POLLING ORGANIZATION } \\
\text { AND DATE }\end{array}$ \\
\hline $\begin{array}{l}\text { "At present corporations are taxed } \\
\text { on the profits they pay out to } \\
\text { stockholders in dividends. Do you } \\
\text { think that the stockholders should } \\
\text { then pay income tax on the } \\
\text { dividends, or should these be free } \\
\text { from tax?" }\end{array}$ & $\begin{array}{l}\text { Pay tax } 51 \% \\
\text { Free from tax } 35 \% \\
\text { No opinion } 14 \%\end{array}$ & $\begin{array}{l}\text { Opinion Research } \\
\text { Corporation (ORC) } \\
\text { Public Opinion Index } \\
01 / 00 / 49\end{array}$ \\
\hline $\begin{array}{l}\text { "Do you see any advantage to the } \\
\text { country as a whole in reducing or } \\
\text { removing the tax on dividends? } \\
\text { What?" }\end{array}$ & $\begin{array}{l}\text { No } 64 \% \\
\text { Will attract more } \\
\text { investment capital } 10 \% \\
\text { Would put more money } \\
\text { in circulation } 4 \% \\
\text { Give more money to } \\
\text { expand } 2 \% \\
\text { Taxes are too high } 2 \% \\
\text { Eliminates double } \\
\text { taxation } 1 \% \\
\text { Don't know } 16 \% \\
\text { [Adds to more than } \\
100 \% \text { due to multiple } \\
\text { responses] }\end{array}$ & $\begin{array}{l}\text { Opinion Research } \\
\text { Corporation (ORC) } \\
\text { Public Opinion Index } \\
01 / 00 / 49\end{array}$ \\
\hline $\begin{array}{l}\text { "Do you think stockholders should } \\
\text { pay income taxes on dividends the } \\
\text { same as they pay on other income } \\
\text { they get?" }\end{array}$ & $\begin{array}{l}\text { Yes } 80 \% \\
\text { No } 12 \% \\
\text { Don't know } 8 \%\end{array}$ & $\begin{array}{l}\text { Opinion Research } \\
\text { Corporation (ORC) } \\
\text { Public Opinion Index } \\
\text { 01/00/49 }\end{array}$ \\
\hline $\begin{array}{l}\text { "It is often said that money made } \\
\text { by corporations is taxed } \\
\text { twice-once when the corporation } \\
\text { pays a tax on profits, and again } \\
\text { when the individual pays an } \\
\text { income tax on the dividends he } \\
\text { receives. Have you heard anything } \\
\text { about that?" }\end{array}$ & $\begin{array}{l}\text { Yes } 36 \% \\
\text { No } 46 \% \\
\text { Don't know } 18 \%\end{array}$ & $\begin{array}{l}\text { Opinion Research } \\
\text { Corporation (ORC) } \\
\text { Public Opinion Index } \\
03 / 00 / 45\end{array}$ \\
\hline
\end{tabular}

181. Source: Searches conducted in DIALOG, Poll database. The dates in this table appear in Westlaw format to facilitate reproduction of our searches. For example, " 00 " indicates that a poll took place over the course of a given month. 


\begin{tabular}{|c|c|c|}
\hline QUESTIONS & RESPONSES & $\begin{array}{c}\text { POLLING ORGANIZATION } \\
\text { AND DATE } \\
\end{array}$ \\
\hline $\begin{array}{l}\text { "It is often said that money made } \\
\text { by corporations is taxed } \\
\text { twice-once when the corporation } \\
\text { pays a tax on profits, and again } \\
\text { when the individual pays an } \\
\text { income tax on the dividends he } \\
\text { receives. Do you think this } \\
\text { situation is all right or that } \\
\text { something ought to be done about } \\
\text { it?" }\end{array}$ & $\begin{array}{l}\text { Yes } 32 \% \\
\text { No } 23 \% \\
\text { Don't know } 45 \%\end{array}$ & $\begin{array}{l}\text { Opinion Research } \\
\text { Corporation (ORC) } \\
\text { Public Opinion Index } \\
03 / 00 / 45\end{array}$ \\
\hline $\begin{array}{l}\text { "In addition to the tax cuts the } \\
\text { President called for in his speech } \\
\text { before Congress, President Reagan } \\
\text { and his economic advisors are } \\
\text { working on another tax cut } \\
\text { program designed to stimulate } \\
\text { investment to make the economy } \\
\text { grow. . . . Would you favor or } \\
\text { oppose ... [e]liminating double } \\
\text { taxation on corporation profits, by } \\
\text { ending taxes paid by stockholders } \\
\text { on dividends they receive, on } \\
\text { which corporations have already } \\
\text { paid income tax, in order to } \\
\text { stimulate more investment by } \\
\text { individuals?" }\end{array}$ & $\begin{array}{l}\text { Favor 63\% } \\
\text { Oppose } 29 \% \\
\text { Not sure } 8 \%\end{array}$ & $\begin{array}{l}\text { Louis Harris \& } \\
\text { Associates (HARRIS) } \\
\text { Harris Survey } \\
03 / 12 / 81\end{array}$ \\
\hline $\begin{array}{l}\text { "People who get income from } \\
\text { dividends on stocks they own in } \\
\text { publicly held corporations pay } \\
\text { personal income taxes on those } \\
\text { dividends that are in excess of } \\
\$ 100 \text {. Corporations paying the } \\
\text { dividends have already paid income } \\
\text { taxes on those dividends, since they } \\
\text { represent profits of the corporations } \\
\text { and corporate profits are taxed. } \\
\text { How do you think dividends should } \\
\text { be taxed-at both the corporate and } \\
\text { the personal level as they now are, } \\
\text { or that only the corporation should } \\
\text { pay taxes on dividends, or that only } \\
\text { the people receiving the dividends } \\
\text { should pay taxes on them?" }\end{array}$ & $\begin{array}{l}\text { At both corporate and } \\
\text { personal level } 37 \% \\
\text { Only corporations } \\
\text { should pay taxes } 35 \% \\
\text { Only people receiving } \\
\text { dividends should pay } \\
\text { taxes } 15 \% \\
\text { Don't know } 14 \%\end{array}$ & $\begin{array}{l}\text { Roper Organization } \\
\text { (ROPER) (Sponsor H \& } \\
\text { R Block) } \\
\text { American Public \& The } \\
\text { Income Tax System } 1978 \\
07 / 00 / 78\end{array}$ \\
\hline
\end{tabular}


